\title{
Instrumentation Recommendations for Volcano Monitoring at U.S. Volcanoes Under the National Volcano Early Warning System
}

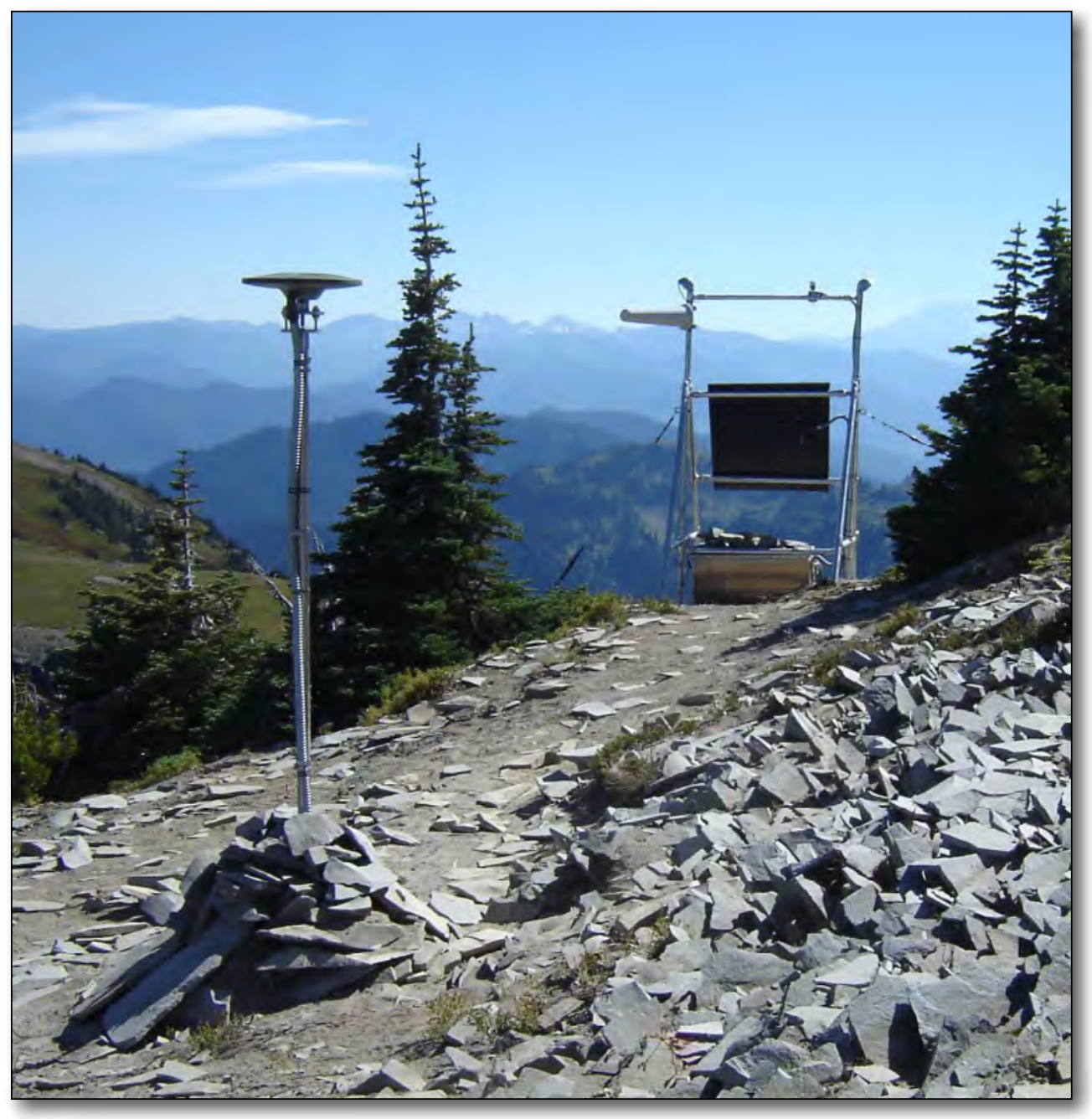

Scientific Investigations Report 2008-5114 
Cover-View of a Global Positioning System (GPS) and seismic monitoring site near Panhandle Gap in Mount Rainier National Park. GPS receiver is in foreground, associated solar panel/radio antenna array is in back. Volcano in background is Mount Adams (Washington). (USGS photograph by Seth Moran). 


\section{Instrumentation Recommendations for Volcano Monitoring at U.S. Volcanoes Under the National Volcano Early Warning System}

By Seth C. Moran, Jeff T. Freymueller, Richard G. LaHusen, Kenneth A. McGee, Michael P. Poland, John A. Power, David A. Schmidt, David J. Schneider, George Stephens, Cynthia A. Werner, and Randall A. White

Scientific Investigations Report 2008-5114 


\title{
U.S. Department of the Interior DIRK KEMPTHORNE, Secretary
}

\author{
U.S. Geological Survey \\ Mark D. Myers, Director
}

U.S. Geological Survey, Reston, Virginia: 2008

This report and any updates to it are available online at:

http://pubs.usgs.gov/sir/2008/5114/

For product and ordering information:

World Wide Web: http://www.usgs.gov/pubprod

Telephone: 1-888-ASK-USGS

For more information on the USGS--the Federal source for science about the Earth, its natural and living resources, natural hazards, and the environment:

World Wide Web: http://www.usgs.gov

Telephone: 1-888-ASK-USGS

Any use of trade, product, or firm names is for descriptive purposes only and does not imply endorsement by the U.S. Government.

Although this report is in the public domain, permission must be secured from the individual copyright owners to reproduce any copyrighted materials contained within this report.

Suggested citation:

Moran, S.C., Freymueller, J.T., LaHusen, R.G., McGee, K.A., Poland, M.P., Power, J.A., Schmidt, D.A., Schneider, D.J., Stephens, G., Werner, C.A., White, R.A., 2008, Instrumentation Recommendations for Volcano Monitoring at U.S.

Volcanoes Under the National Volcano Early Warning System: U.S. Geological Survey Scientific Investigations Report $2008-5114,47 p$.

\section{Cataloging-in-Publication data are on file with the Library of Congress (URL http://www.loc.gov/).}

Produced in the Western Region, Menlo Park, California

Manuscript approved for publication, June 23, 2008

Text edited by George Havach

Layout and design by Luis Menoyo 


\section{Contents}

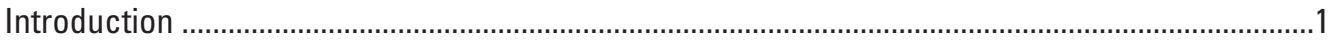

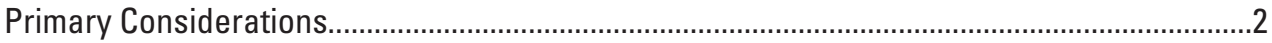

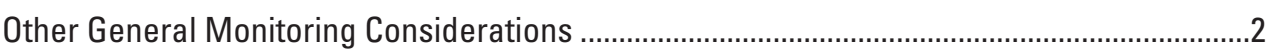

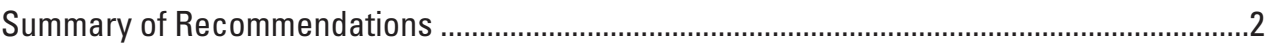

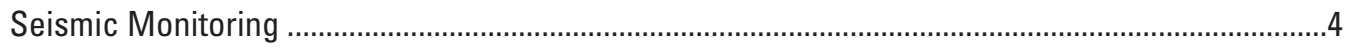

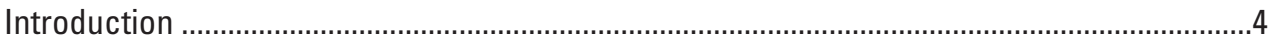

Seismic Monitoring—Required Capabilities......................................................................

1. Detection of Changes in Earthquake Location, Seismic Energy Release, Event Type, and Source Properties .....................................................................................

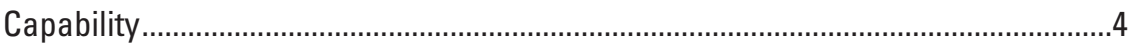

Detection and location of hypocenters.............................................................

Measurement of low-frequency (long period) seismicity..................................

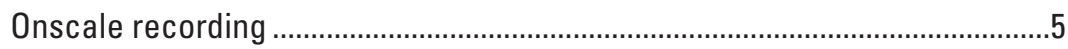

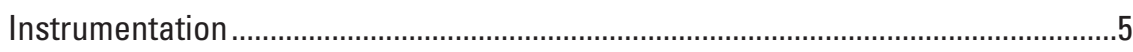

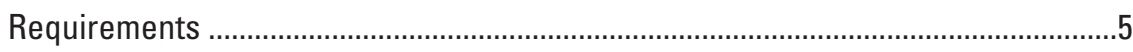

2. Detection of Changes in Localized Stress Fields .....................................................

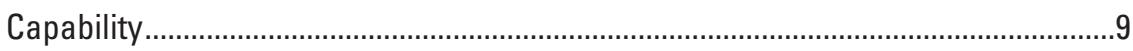

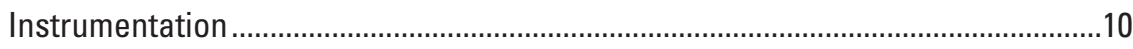

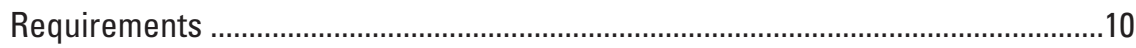

3. Detection of Changes in Seismic Source and (or) Path Over Time .............................10

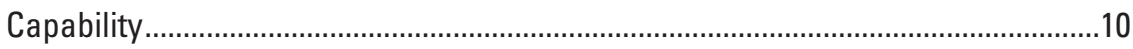

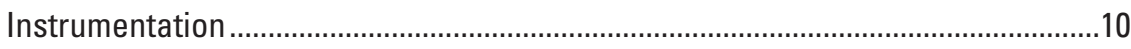

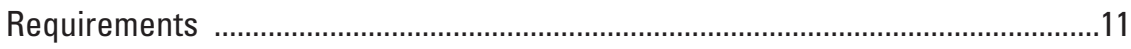

4. Detection and Determination of Source Mechanisms for Very Long Period Events 11

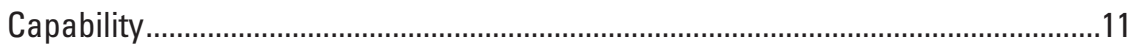

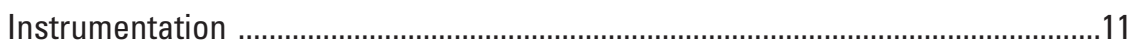

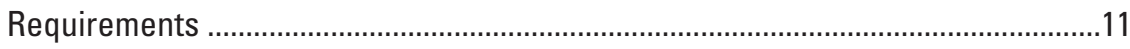

5. Explosion Detection and Monitoring .........................................................................11

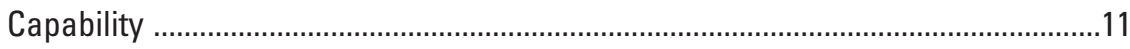

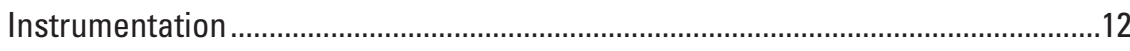

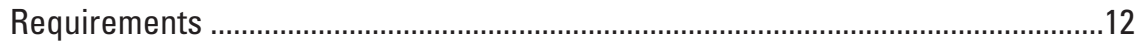

Summary—Recommendations for Level 1-4 Networks ......................................................12

Deformation Monitoring ........................................................................................................

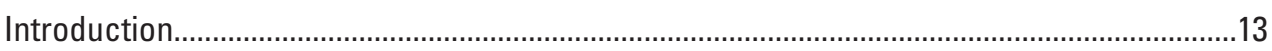

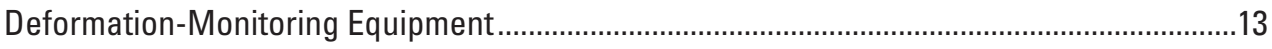

Global Positioning System....................................................................................14

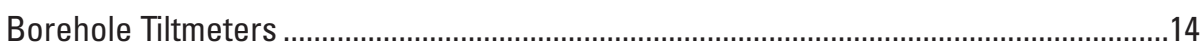

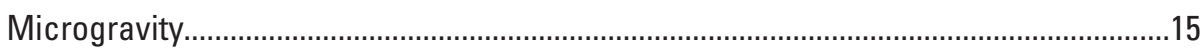

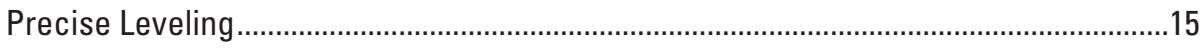

Interferometric Synthetic Aperture Radar ……........................................................

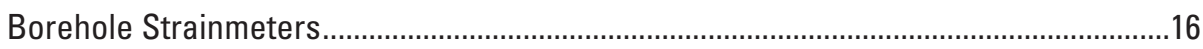

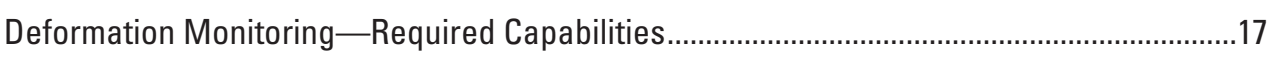

1. Detection of Displacement-Pattern Changes ……..................................................17

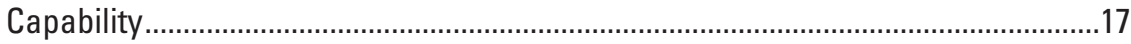




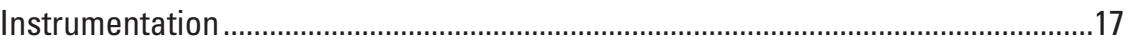

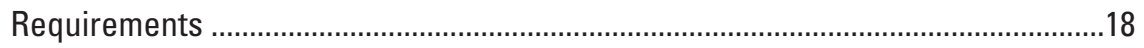

2. Location of Deformation Sources and Estimation of Source Magnitude and

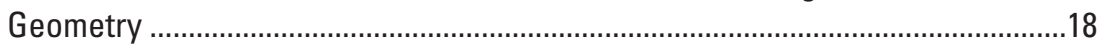

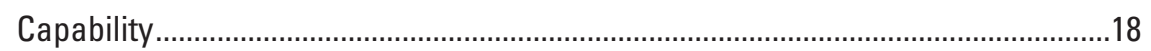

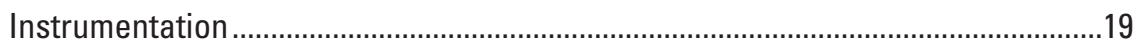

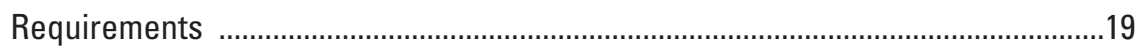

3. Distinction of Volcanic from Nonvolcanic Surface Deformation.................................20

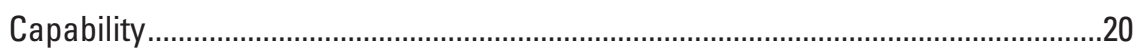

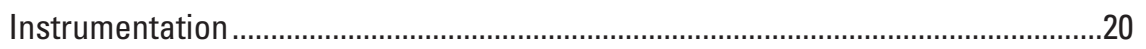

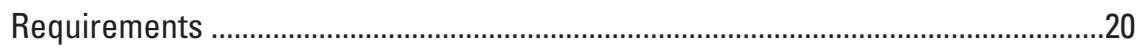

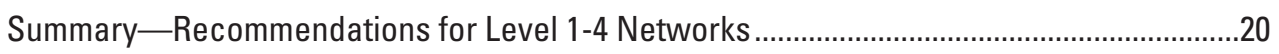

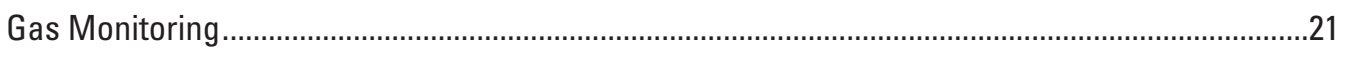

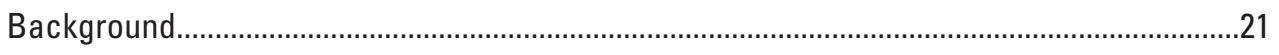

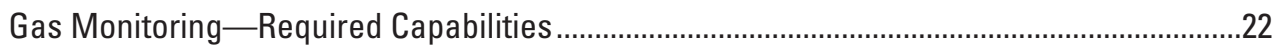

1. Establishment of a Long-Term Geochemical Baseline by Sampling and Analysis of

Fumaroles and Hot Springs and Other Field Measurements...............................22

2. Establishment of a Gas-Emission-Rate Baseline .....................................................22

3. Continuous Monitoring of Total Gas Output, Fumarole Geochemistry, and Soil Gases

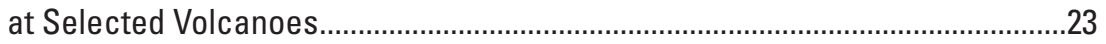

4. Deployment of Ground-Based Instrumentation...........................................................

5. Repeat Airborne Measurements of Volcanic Plumes ...................................................23

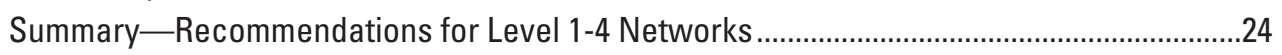

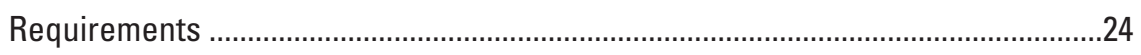

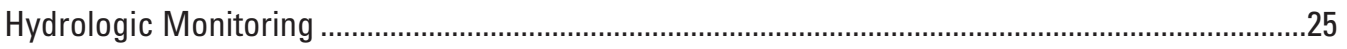

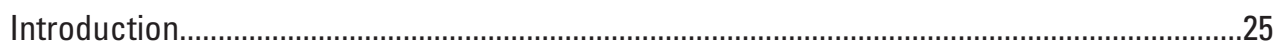

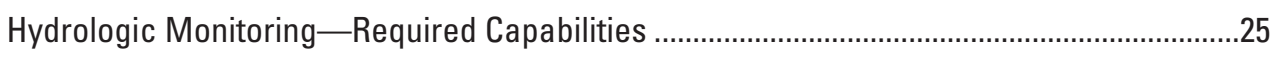

1. Detection of Changes in Water Level, Chemistry, and Temperature ("Water

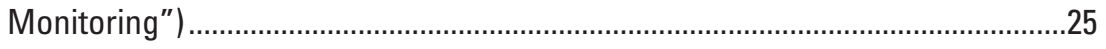

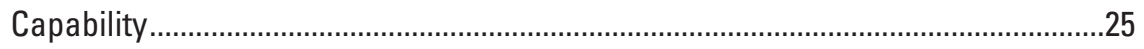

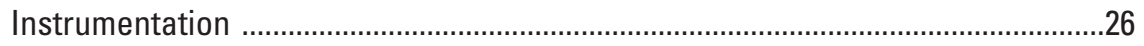

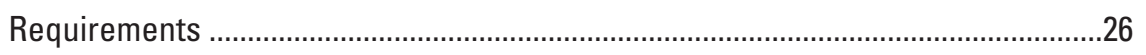

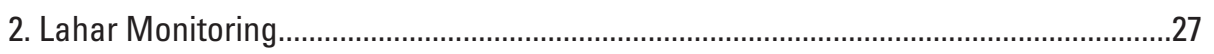

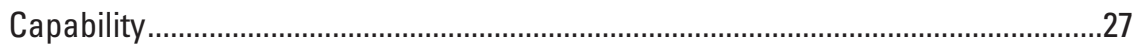

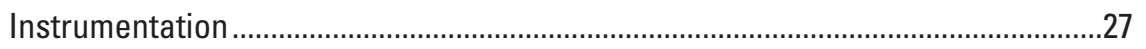

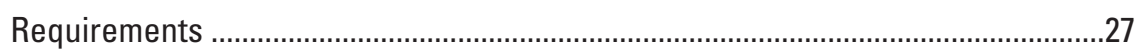

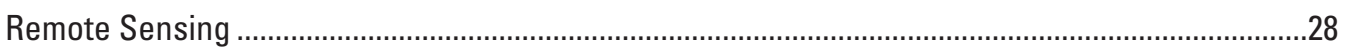

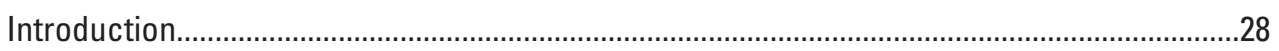

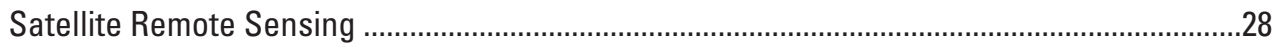

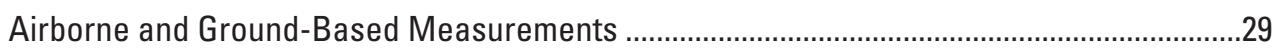

Remote Sensing — Required Capabilities ........................................................................29

1. Detection, Tracking, and Measurement of Volcanic Clouds .....................................29

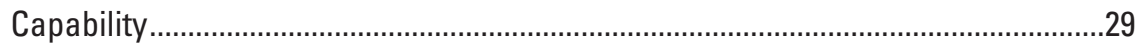

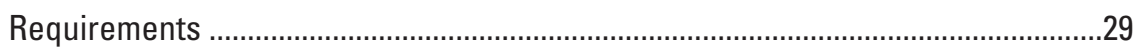

2. Characterization of Thermal Emissions ..................................................................30

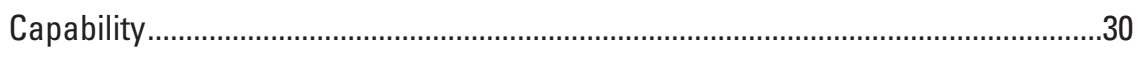




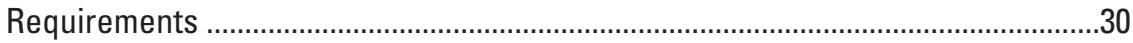

3. Measurement of $\mathrm{SO}_{2}$ Emissions …………………................................................

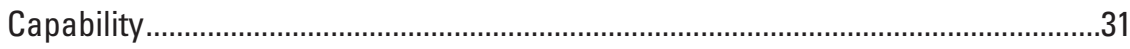

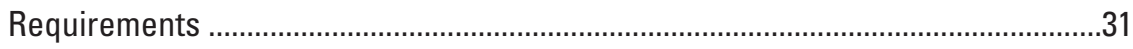

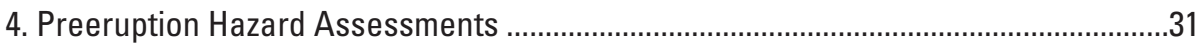

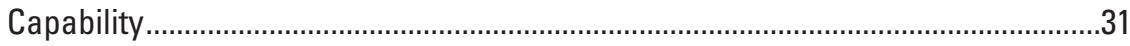

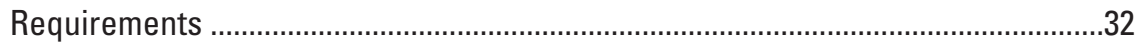

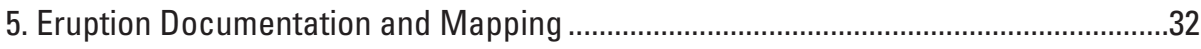

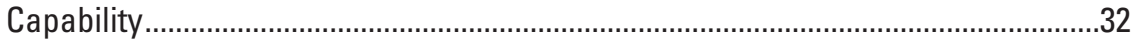

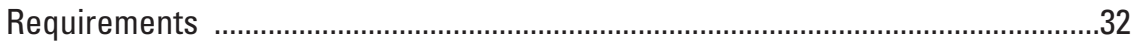

6. Staffing Requirements and Operational-Satellite Data Access .................................33

Summary-Recommendations for Level 1-4 Networks.................................................33

Boreholes and Borehole Instrumentation .....................................................................................3

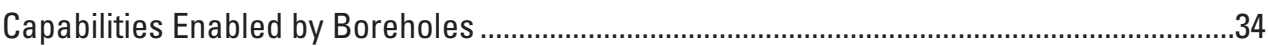

1. High-Quality Recordings........................................................................................

2. Direct Measurements of Subsurface Geology and Hydrology ……...............................34

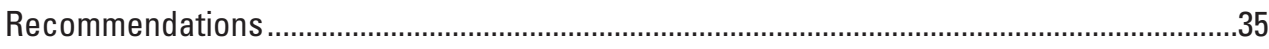

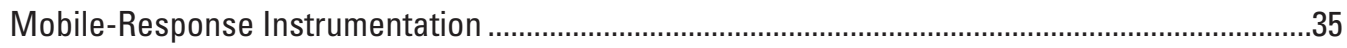

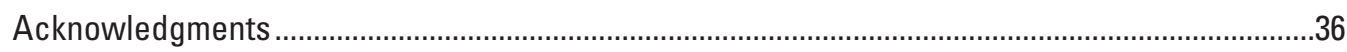

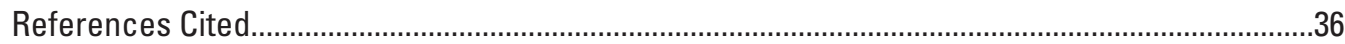

\section{Figures}

Figure 1. Shaded-relief images of Mount St. Helens, Wash., and Mount Rainier, Wash., showing locations of seismic stations (triangles) as of summer 2004...............................7

Figure 2. Hypocentral depth versus time for 7,016 earthquakes in the Pacific Northwest Seismic Network's “Rainier-like" network ...........................................................................

Figure 3. Strain rate versus averaging interval for types of deformation monitoring described

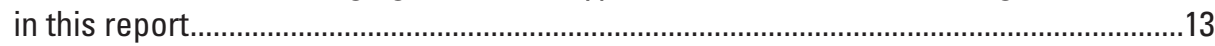

Figure 4. Sensitivity plot illustrating uncertainty in geodetic-model parameters (for example, depth or volume change in a subsurface source) versus number of GPS stations ........18

\section{Tables}

Table 1. Instrumentation to be installed and routine baseline information to be collected at

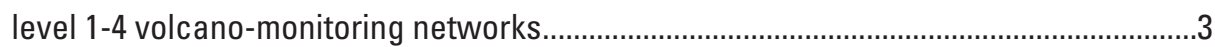

Table 2. Mobile-rapid-response (cache) instrumentation ...............................................................

Table 3. Initial estimates of number of degassing U.S. volcanoes and types of degassing phenomena per threat level...........................................................................................

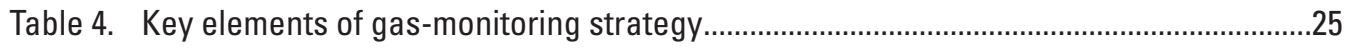


This page intentionally left blank 


\title{
Instrumentation Recommendations for Volcano Monitoring at U.S. Volcanoes Under the National Volcano Early Warning System
}

\author{
By Seth C. Moran, Jeff T. Freymueller' ${ }^{1}$, Richard G. LaHusen, Kenneth A. McGee, Michael P. Poland, John A. \\ Power, David A. Schmidt², David J. Schneider, George Stephens ${ }^{3}$, Cynthia A. Werner, and Randall A. White
}

\section{Introduction}

As magma moves toward the surface, it interacts with anything in its path: hydrothermal systems, cooling magma bodies from previous eruptions, and (or) the surrounding "country rock." Magma also undergoes significant changes in its physical properties as pressure and temperature conditions change along its path. These interactions and changes lead to a range of geophysical and geochemical phenomena. The goal of volcano monitoring is to detect and correctly interpret such phenomena in order to provide early and accurate warnings of impending eruptions. Given the well-documented hazards posed by volcanoes to both ground-based populations (for example, Blong, 1984; Scott, 1989) and aviation (for example, Neal and others, 1997; Miller and Casadevall, 2000), volcano monitoring is critical for public safety and hazard mitigation. Only with adequate monitoring systems in place can volcano observatories provide accurate and timely forecasts and alerts of possible eruptive activity.

At most U.S. volcanoes, observatories traditionally have employed a two-component approach to volcano monitoring: (1) install instrumentation sufficient to detect unrest at volcanic systems likely to erupt in the not-too-distant future; and (2) once unrest is detected, install any instrumentation needed for eruption prediction and monitoring. This reactive approach is problematic, however, for two reasons.

1. At many volcanoes, rapid installation of new groundbased instruments is difficult or impossible. Factors that complicate rapid response include (a) eruptions that are preceded by short (hours to days) precursory sequences of geophysical and (or) geochemical activity, as occurred at Mount Redoubt (Alaska) in 1989 (24 hours), Anatahan (Mariana Islands) in 2003 (6 hours), and Mount St. Helens (Washington) in 1980 and 2004 (7 and 8 days, respectively); (b) inclement weather conditions, which

\footnotetext{
${ }^{1}$ University of Alaska, Fairbanks.

${ }^{2}$ University of Oregon, Eugene, Oreg.

${ }^{3}$ NOAA National Environmental Satellite, Data, and Information Service (NESDIS).
}

may prohibit installation of new equipment for days, weeks, or even months, particularly at midlatitude or high-latitude volcanoes; (c) safety factors during unrest, which can limit where new instrumentation can safely be installed (particularly at near-vent sites that can be critical for precursor detection and eruption forecasting); and (d) the remoteness of many U.S. volcanoes (particularly those in the Aleutians and the Marianas Islands), where access is difficult or impossible most of the year. Given these difficulties, it is reasonable to anticipate that ground-based monitoring of eruptions at U.S. volcanoes will likely be performed primarily with instruments installed before unrest begins.

2. Given a growing awareness of previously undetected phenomena that may occur before an eruption begins, at present the types and (or) density of instruments in use at most U.S. volcanoes is insufficient to provide reliable early warning of volcanic eruptions. As shown by the gap analysis of Ewert and others (2005), a number of U.S. volcanoes lack even rudimentary monitoring. At those volcanic systems with monitoring instrumentation in place, only a few types of phenomena can be tracked in near-real time, principally changes in seismicity, deformation, and large-scale changes in thermal flux (through satellite-based remote sensing). Furthermore, researchers employing technologically advanced instrumentation at volcanoes around the world starting in the 1990s have shown that subtle and previously undetectable phenomena can precede or accompany eruptions. Detection of such phenomena would greatly improve the ability of U.S. volcano observatories to provide accurate early warnings of impending eruptions, and is a critical capability particularly at the very high-threat volcanoes identified by Ewert and others (2005).

For these two reasons, change from a reactive to a proactive volcano-monitoring strategy is clearly needed at U.S. volcanoes. Monitoring capabilities need to be expanded at virtually every volcanic center, regardless of its current state of unrest, with particular emphases on real-time data transmission and increasing the diversity, quality, and quantity of 
instrumentation at U.S. volcano observatories. In this report, we present recommendations for the types and numbers of instruments that should be deployed to monitor U.S. volcanoes. These recommendations are the result of discussions among members of a panel of government- and universitybased scientists about the status and future directions of volcano monitoring, with discussions framed by the U.S. Geological Survey (USGS)'s National Volcano Early Warning System (NVEWS) initiative (Ewert and others, 2005).

\section{Primary Considerations}

The primary focus of the panel was to generate instrumentation recommendations for the four monitoring levels defined by Ewert and others (2005). To do so, we first determined the capabilities required for adequate volcano monitoring, with particular emphasis on those capabilities that have been shown to be important at one or more volcanoes in identifying precursory activity or improving the accuracy of eruption forecasts. We then determined the instrumentation levels required to achieve these capabilities. To arrive at specific numbers of instruments per monitoring level, we used published studies and (or) modeling, as appropriate, to assess whether a particular number or geometry of instruments was sufficient to enable a specific capability. We largely ignored such issues as cost, permitting requirements, and logistic difficulties, which can vary greatly from volcano to volcano and cannot be addressed by a generic standard. In fact, many U.S. volcanoes are remote, in wilderness areas, and (or) subject to harsh weather conditions. Such factors may limit the type and number of instruments that can be deployed at specific volcanoes.

\section{Other General Monitoring Considerations}

Given that volcanoes are commonly in remote areas with hostile climates, occasional failures of ground-based instrument sites are expectable. Additionally, some stations may be destroyed during eruptions. Therefore, each volcano must be sufficiently instrumented to ensure continuity of data flow during inclement weather or eruptive activity. Specifically, networks of ground-based instruments need to be redundant both in numbers of instruments and in telemetry paths. Our recommendations for numbers of ground-based instruments take this requirement into account by assuming that at any given time, 10-20 percent of such instruments may be inoperable.

Effective volcano monitoring requires that data be transmitted in real time to observatories. Although more data can be transmitted by digital telemetry, experience has shown that analog telemetry is more robust when transmitting through ash, snow, ice, and dense vegetation, any of which can be expected at most U.S. volcanoes. Thus, monitoring networks should utilize a mix of analog and digital real-time telemetry, and redundancy should be built into any telemetered network to ensure that no single point of failure could cause a loss of signals from all instruments in the network.

Our recommendations here are limited to instrumentation and do not encompass other critical issues, such as staffing, infrastructure, and software development. Installation, operation, troubleshooting, and maintenance of NVEWS instrumentation will require a significant increase in the number of field-based personnel with experience in mechanical and electrical engineering. Furthermore, real-time data availability will require significant investment in telemetry backbones, including satellite-, microwave-, and Internet-based datatransmission systems. Robustness of field installations will also require a significant investment in infrastructure, particularly power systems. Finally, significant software development will be required to enable most of the capabilities described in this report, particularly those with real-time potential. These and other critical issues are beyond the scope of this report but nevertheless must be addressed in concert with instrumentation.

\section{Summary of Recommendations}

In this report, we subdivide our discussion of capabilities and instrumentation into five discipline-specific areas: seismology, geodesy, gas geochemistry, hydrology, and remote sensing. In addition to these broad categories, we address general cross-disciplinary issues, including borehole instrumentation and mobile rapid response to developing volcanic crises, in separate sections. Summaries of our recommendations for instrumentation at four different monitoring levels are listed in tables 1 and 2 . These levels are directly linked to the volcanic-threat rankings of Ewert and others (2005), so that, for example, level 1 networks would be deployed on very lowthreat volcanoes, such as Mount Jefferson (Oregon), and level 4 networks would be deployed on very high-threat volcanoes, such as Mount Rainier (Washington). We emphasize that these numbers reflect only a generic standard; the significant variation in spatial scale among U.S. volcanic centers makes a "one size fits all" standard impractical. In terms of spatial scale, " $5 \mathrm{~km}$ from the volcanic center" has one meaning for such isolated stratovolcanoes as Augustine Volcano (Alaska) but quite a different meaning for such large volcanic systems as Medicine Lake (California), Yellowstone (Wyoming), and Kîlauea (Hawai i). The distances listed in table 1 should be interpreted as "distances relative to areas likely to have eruptive products coming out of the ground", reflecting the need for larger networks at Kīlauea and smaller networks at Augustine Volcano. Owing to this variation in spatial scale, evaluations as to whether a given network meets level 1-4 standards should be made on an individual-volcano basis.

It is the consensus of the panel that the instrumentation levels described in this report are the minimum required to provide adequate public safety at U.S. volcanoes over the next 10-20 years. Furthermore, a primary key to detecting volcanic unrest is understanding the background, or "normal," levels of 
Table 1. Instrumentation to be installed and routine baseline information to be collected at level 1-4 volcano-monitoring networks.

\begin{tabular}{|c|c|c|c|}
\hline $\begin{array}{l}\text { Monitoring } \\
\text { Level: }\end{array}$ & 1 & 2 & 3 \\
\hline Seismic & $\begin{array}{c}\text { Five seismic stations located } \\
\text { within } 200 \mathrm{~km} \text {, including } \\
\text { two located within } 50 \mathrm{~km} \text {. }\end{array}$ & $\begin{array}{c}\text { Five seismic stations located } \\
\text { within } 50 \mathrm{~km} \text {, including } \\
\text { two located within } 10 \mathrm{~km} \text {. }\end{array}$ & $\begin{array}{l}\text { Six to eight seismic stations } \\
\text { located within } 20 \mathrm{~km} \text {, in- } \\
\text { cluding two or three located } \\
\text { within } 5 \mathrm{~km} \text {; at least one } \\
\text { broadband station located } \\
\text { within } 5 \mathrm{~km} \text {. }\end{array}$ \\
\hline
\end{tabular}

4

12-20 seismic stations located within $20 \mathrm{~km}$, including at least two or three located within $5 \mathrm{~km}$, and at least six broadband stations (at least two located within 5 $\mathrm{km}$ ). Collocated with these stations should be at least one strong-motion station within $5 \mathrm{~km}$, and at least two infrasonic stations with two 2 sensors per station.

\begin{tabular}{|c|c|c|c|c|}
\hline Deformation & $\begin{array}{l}\text { Occasional InSAR, GPS, and } \\
\text { (or) leveling surveys. }\end{array}$ & $\begin{array}{l}\text { Periodic (1-10 years) InSAR, } \\
\text { GPS, and (or) leveling sur- } \\
\text { veys; one continuous-mode } \\
\text { GPS station located within } \\
10 \mathrm{~km} \text {. }\end{array}$ & $\begin{array}{l}\text { 7-10 continuous-mode GPS } \\
\text { stations, four located } \\
\text { within } 5-10 \mathrm{~km} \text {, one of } \\
\text { which is outside expected } \\
\text { area of deformation; four } \\
\text { to six borehole tiltmeters } \\
\text { located within 5-10 km. } \\
\text { Supplemented by InSAR, } \\
\text { GPS, leveling, and (or) } \\
\text { microgravity surveys every } \\
\text { 1-5 years. }\end{array}$ & $\begin{array}{l}\text { 16-20 continuous-mode GPS } \\
\text { stations, eight located } \\
\text { within 5-10 km, two located } \\
\text { outside expected area of } \\
\text { deformation; } 5 \text {-10 borehole } \\
\text { tiltmeters located within } \\
\text { 5-10 km; one continuous } \\
\text { gravimeter located near } \\
\text { volcanic center; Monthly } \\
\text { InSAR surveys.. }\end{array}$ \\
\hline Hydrology & $\begin{array}{l}\text { Baseline water chemistry/ } \\
\text { temperature measurements } \\
\text { at significant lakes/spring/ } \\
\text { streams every 10-20 years; } \\
\text { for volcanoes with nearby } \\
\text { population centers and } \\
\text { (or) infrastructure, assess } \\
\text { hazards for each drainage } \\
\text { with LAHARZ program; } \\
\text { response and survey equip- } \\
\text { ment resides in equipment } \\
\text { cache. }\end{array}$ & $\begin{array}{l}\text { Same as for level 1, plus } \\
\text { baseline water chemistry/ } \\
\text { temperature measurements } \\
\text { at significant lakes/spring/ } \\
\text { streams every 5-10 years. }\end{array}$ & $\begin{array}{l}\text { Same as for level 2, plus } \\
\text { baseline water chemistry/ } \\
\text { temperature measurements } \\
\text { at significant lakes/spring/ } \\
\text { streams every 3-5 years. }\end{array}$ & $\begin{array}{l}\text { Same as for level 3, plus wa- } \\
\text { ter- chemistry/temperature } \\
\text { measurement at significant } \\
\text { lakes/spring/streams every } \\
\text { 1-5 years; install several } \\
\text { continuous probes at two or } \\
\text { three volcanoes. }\end{array}$ \\
\hline Remote sensing & $\begin{array}{l}\text { Daily scans of routinely } \\
\text { collected satellite imagery } \\
\text { to detect ash clouds, gas } \\
\text { plumes, and thermal } \\
\text { anomalies; acquire baseline } \\
\text { imagery for hazard assess- } \\
\text { ments and mapping. }\end{array}$ & Same as for level 1 & $\begin{array}{l}\text { Same as for level } 1 \text {, plus } \\
\text { install one telemetered } \\
\text { camera }\end{array}$ & $\begin{array}{l}\text { Same as for level } 1, \text { plus } \\
\text { install two or three } \\
\text { telemetered cameras, one } \\
\text { low-light camera. }\end{array}$ \\
\hline Gas & & $\begin{array}{l}\text { Compile list of candidate sites } \\
\text { for ground-based, airborne, } \\
\text { or continuous gas monitor- } \\
\text { ing; baseline fumarole- } \\
\text { chemistry measurements } \\
\text { every 5-10 years; airborne } \\
\text { plume measurements if a } \\
\text { plume exists; and continu- } \\
\text { ous measurements where } \\
\text { appropriate. }\end{array}$ & $\begin{array}{l}\text { Same as for level 2, plus base- } \\
\text { line fumarole-chemistry } \\
\text { measurements every 3-5 } \\
\text { years, airborne measure- } \\
\text { ments every 3-5 years } \\
\text { where appropriate, and } \\
\text { long-term deployments and } \\
\text { (or) measurement surveys } \\
\text { where appropriate. }\end{array}$ & $\begin{array}{l}\text { Same as for level 3, plus base- } \\
\text { line fumarole-chemistry } \\
\text { measurements every 1-2 } \\
\text { years, annual airborne } \\
\text { measurements, long-term } \\
\text { deployments and (or) } \\
\text { measurement surveys at } \\
\text { volcanoes with adequate } \\
\text { degassing levels. }\end{array}$ \\
\hline
\end{tabular}


Table 2. Mobile-rapid-response (cache) instrumentation.

[Note that with time, specific pieces of equipment listed here may become obsolete]

\begin{tabular}{|c|c|}
\hline Type of monitoring category & Equipment \\
\hline Deformation & $\begin{array}{l}30 \text { dual-frequency GPS receivers; } 10 \text { shallow borehole tiltmeters; } 2 \text { gravimeters; enough solar panels, ra- } \\
\text { dios, and other infrastructure to allow installation within } 24 \text { hours. }\end{array}$ \\
\hline Remote sensing & $\begin{array}{l}\text { One ground-based and one airborne thermal radiometer; two airborne-based FLIR; four telemetered digital } \\
\text { cameras; two telemetered low-light cameras; two ground-based Doppler radar systems; lightning-detec- } \\
\text { tion system. }\end{array}$ \\
\hline Gas & $\begin{array}{l}\text { Five scanning UV spectrometers; two } \mathrm{SO}_{2}-\mathrm{CO}_{2} \text { monitoring stations; one automated soil- } \mathrm{CO}_{2} \text {-flux-moni- } \\
\text { toring station; one weather station (with repeater); two portable UV spectrometer systems; one portable } \\
\mathrm{H}_{2} \mathrm{~S} \text {-measurement system; one portable soil- } \mathrm{CO}_{2} \text {-flux-monitoring system; one portable multigas analyzer; } \\
\text { one airborne infrared spectrometer; one airborne ultraviolet spectrometer; two airborne electrochemical } \\
\text { sensors; one GPS receiver with NMEA output and aircraft antenna; one master datalogger for all airborne } \\
\text { instruments; one multichannel recorder for inflight display; one laptop computer for measurement and } \\
\text { instrument control. }\end{array}$ \\
\hline
\end{tabular}

activity at individual volcanoes, an understanding that requires installation of ground-based instruments before a period of unrest begins. Therefore, installation of ground-based instrumentation regardless of the current state of unrest at a given volcano is critical, particularly at sites within 5 to $10 \mathrm{~km}$ of areas where conditions are likely to become too dangerous once unrest begins.

\section{Seismic Monitoring}

\section{Introduction}

Seismic unrest is commonly observed before eruptions because magma movement usually generates some form of seismic energy by rock breakage (earthquakes), fluid or gas flow through cracks (earthquakes, tremor), and other phenomena. Thus, seismometers are generally the most common type of monitoring equipment deployed at volcanoes. Interpretation of seismic signals is best done within the context of other observations, such as surface deformation, gas geochemistry, thermal emissions, or visual observations (for example, Nye and others, 2002), but only if seismicity characteristics such as frequency, amplitude, and earthquake location are adequately recorded and constrained. Therefore, our focus in this section is to determine the levels of instrumentation required to produce high-quality, well-constrained seismic observations, observations which have been shown elsewhere to be important for providing early warning of impending eruptions. We do not intend to comprehensively review of the field of volcano seismology but, instead, to summarize what we consider to be the capabilities required for routine real-time seismic monitoring.

\section{Seismic Monitoring—Required Capabilities}

\section{Detection of Changes in Earthquake Location, Seismic Energy Release, Event Type, and Source Properties}

\author{
Capability
}

Detection and location of hypocenters.

Increases in the occurrence and size of earthquakes have long been known to precede volcanic eruptions, as during the eruptions of Usu Volcano (Japan) in 1910 (Omori, 1911) and Mauna Loa (Hawai'i) in 1914 (Wood, 1915). Marked increases in earthquake rate have been observed at volcanoes as diverse in size, chemistry, and eruptive style as Kîlauea (Hawai' i) (Klein and Koyanagi, 1988), Mount St. Helens (Washington) (Malone and others, 1981; Moran and others, 2008a), Redoubt Volcano (Alaska) (Lahr and others, 1994), and Mount Pinatubo (Philippines) (Harlow and others, 1996). Commonly, precursory seismic sequences may be entirely composed of smaller $(M<2)$ earthquakes, as recorded at Mount Spurr (Alaska) in 1992 (Power and others, 1995). 
Earthquake hypocenters have been observed to migrate over time in association with magma intrusions at Long Valley caldera (California) (Prejean and others, 2003), and in advance of eruptions at Augustine Volcano (Alaska) in 1986 (Power, 1988), Mount Pinatubo in 1991 (Harlow and others, 1996), Miyakejima (Japan) in 2000 (Nakada and others, 2005), and Mount St. Helens in 2004 (Moran and others, in press a; Thelen and others, in press). Battaglia and others (2005) used a newly-developed tremor-location technique to show that tremor locations migrated before the 1998 eruption of Piton de la Fournaise (Réunion Island). Finally, relocation of similar events ("multiplets") has yielded precise relative locations that have proved to be important for constraining magmatic processes in conduits (for example, Prejean and others, 2003; Rowe and others, 2004; Thelen and others, in press).

\section{Measurement of low-frequency (long period) seismicity}

In addition to standard earthquakes, commonly referred to as volcanotectonic events, volcanism is commonly associated with other types of seismicity, including seismic tremor, hybrid earthquakes, and low-frequency events. Changes in seismicity have been observed before many eruptions, such as from dominantly volcanotectonic to dominantly low-frequency earthquakes in the hours, days, and weeks preceding the onset of eruptive activity at Mount St. Helens in 1980-86 and 2004 (Endo and others, 1981; Malone and others, 1983; Moran and others, in press a), Mount Pinatubo in 1991 (Harlow and others, 1996), and Soufriére Hills Volcano (Montserrat) in 1995 (Gardner and White, 2002). Increases in deep, low-frequency earthquakes at lower-crustal and midcrustal depths were observed before the eruptions of Mount Pinatubo in 1991 (White, 1996) and Shishaldin Volcano (Alaska) in 1999 (Power and others, 2004b) and with the volcanic unrest at Mount Spurr in 2004 (Power and others, 2004a). In some eruptions, such as that of the Shishaldin in 1999 (Thompson and others, 2002), precursory seismicity was dominated by seismic tremor, with only a few earthquakes. Detection and tracking of seismic tremor has proved important at several volcanoes for accurate eruption forecasting and tracking of ongoing eruptions (for example, McNutt, 1994; McNutt and others, 1995; Thompson and others, 2002; Battaglia and others, 2006; Takagi and others, 2006).

\section{Onscale recording}

A final required capability for seismic monitoring is onscale recording of seismicity. Tracking long-term seismicity rates and energy release through such techniques as real-time seismic-amplitude measurement (RSAM; Endo and Murray, 1991) at volcanoes has proved time and again to be an effective means of anticipating renewed volcanic activity. At many volcanoes, however, seismicity before and (or) accompanying an eruption intensifies to the point where short-period analog seismometers within 5,10 or even $20 \mathrm{~km}$ become saturated and so are less useful for tracking changes in seismicity (for example, at Mount St. Helens in 1980 (Endo and others,
1981; Malone and others, 1981) and 2004 (Moran and others, in press a)). This problem can be solved by installing digital seismometers, such as broadband and strong-motion sensors, within $10 \mathrm{~km}$ of a volcanic center, thus greatly increasing the seismic-energy range over which onscale recording can be obtained, and ensuring continuing ability to track changes in seismic-energy release, event rate, and event type during the most energetic phases of a precursory or eruptive sequence.

\section{Instrumentation}

In principle, a single seismic station can be used to track earthquake rate and seismic- energy release; however, at least two stations are required for distinguishing between the signals produced by volcanic and nonvolcanic (wind, aircraft, manmade explosions, electronic interference, and so on) phenomena. At least four seismic stations are required to locate earthquakes, but for redundancy and location quality it is best to have at least six because the accuracy of earthquake locations increases with greater station density and spatial distribution (figs. 1, 2). Although short-period vertical-component instruments are sufficient for these capabilities, earthquakelocation accuracy is improved when $S$-wave-arrival-time data are included, and $S$-wave arrival times are most reliable when determined by using three-component seismometers. Moreover, adequate detection of all types of volcano seismicity requires broadband and (or) strong-motion seismometers, which also enable detection of very long period events and onscale recordings of energetic seismicity.

\section{Requirements}

Level 1—Detect $M>1.5$ earthquakes; crudely locate $M>3$ earthquakes.

Techniques/instrumentation:

- At least two seismic stations located within $50 \mathrm{~km}$ of the volcanic center

- At least five total seismic stations located within 200 $\mathrm{km}$ of the volcanic center (that is, volcano falls within a regional seismic network)

Level 2-Detect $M>1$ earthquakes; crudely locate $M>2$ earthquakes; determine event type; detect energetic seismic tremor.

Techniques/instrumentation:

- At least two seismic stations located within $10 \mathrm{~km}$ of the volcanic center

- At least five total seismic stations located within $50 \mathrm{~km}$ of the volcanic center

Level 3-Detect $M>0.5$ earthquakes; accurately locate $M>1$ earthquakes; determine event type; detect seismic tremor; onscale recording of energetic seismicity on at least one station; detect very long period events. 

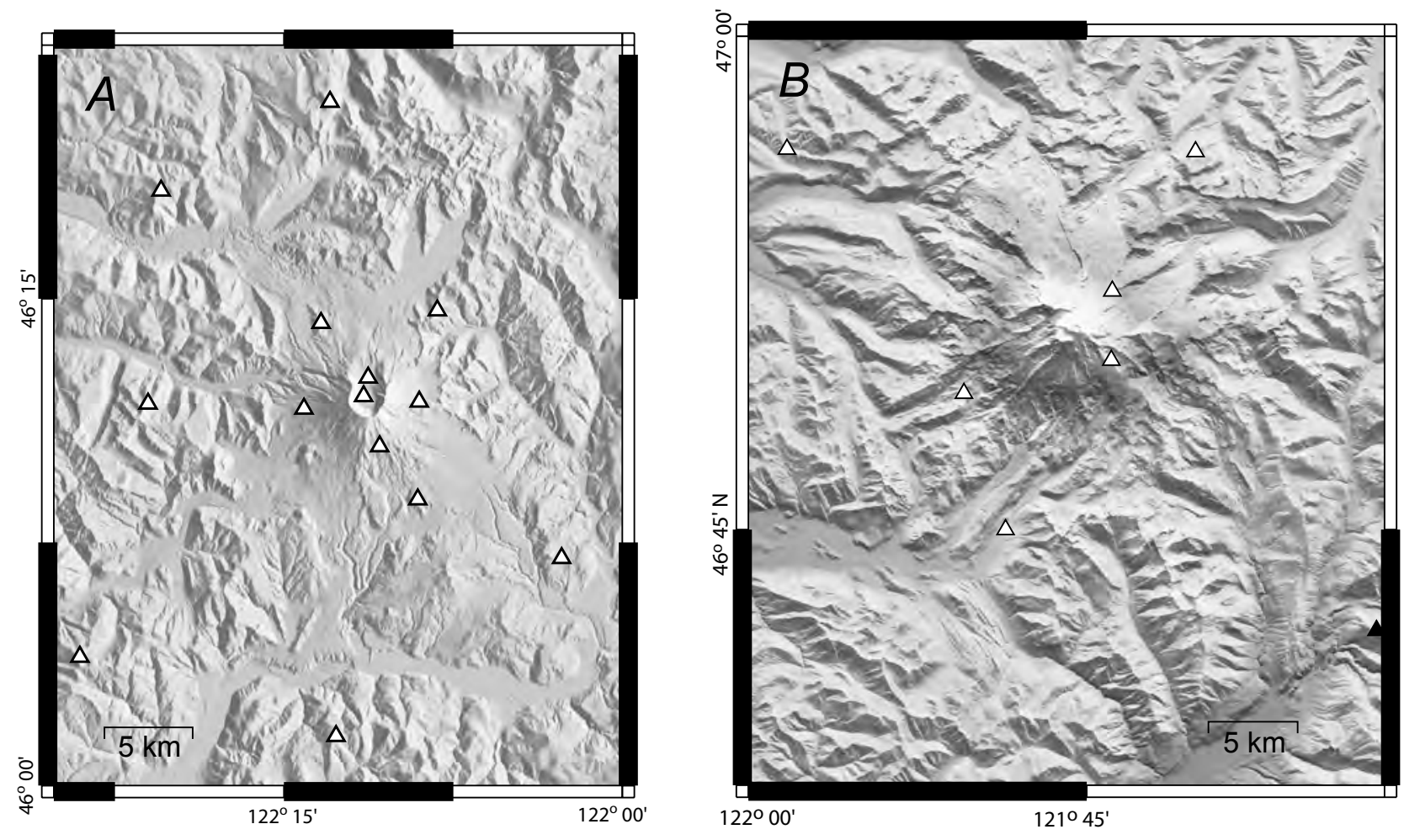

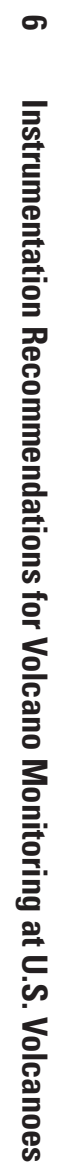

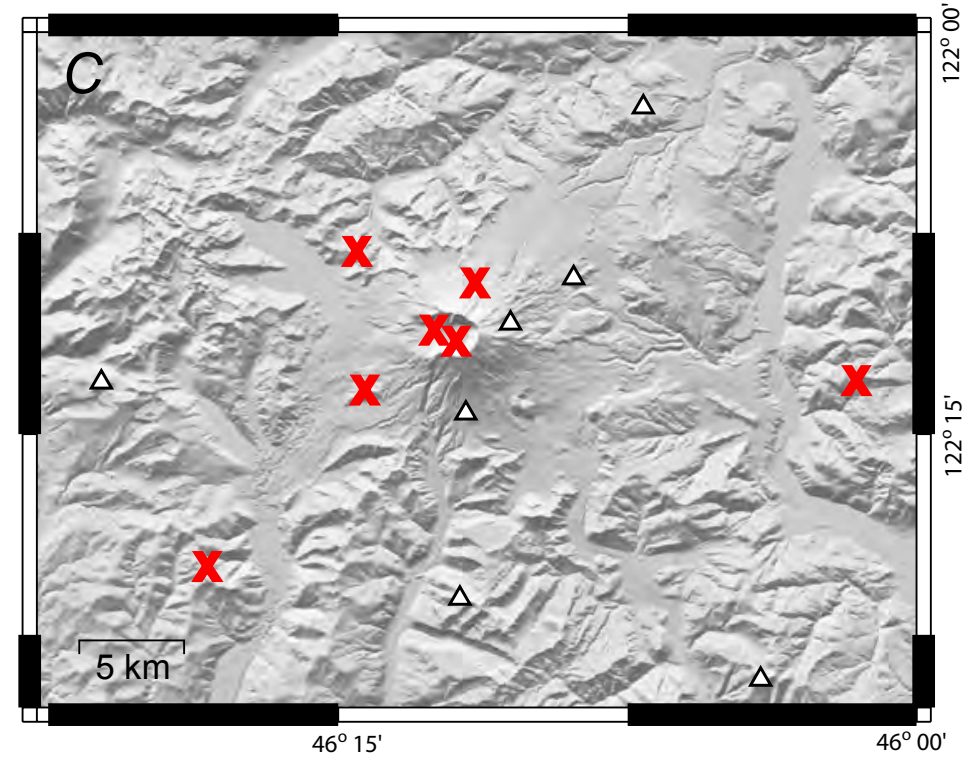



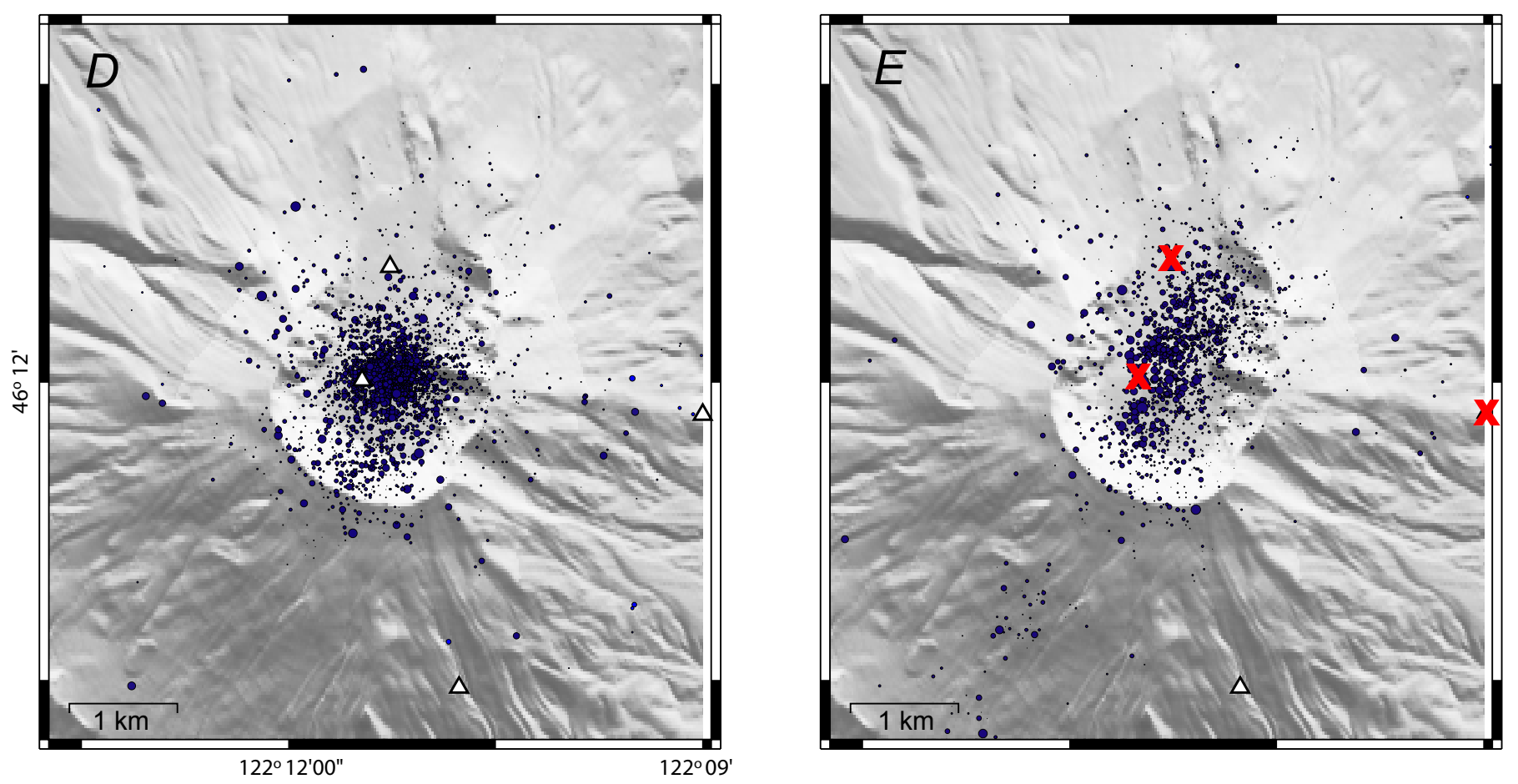

Figure 1. Shaded-relief images of Mount St. Helens, Wash. $(A, C-E)$, and Mount Rainier, Wash. $(B)$, showing locations of seismic stations (triangles) as of summer 2004. $A$, Network of 14 seismic stations at Mount St. Helens. B, Network of six seismic stations at Mount Rainier. C, Same image as in figure $A$, rotated so that north is to left and number of seismic stations is reduced to 7 (red Xs, eliminated stations) to mimic monitoring network at Mount Rainier shown in figure B. D. Area of main crater of Mount St. Helens, showing locations of 7,016 well-recorded earthquakes (maximum azimuthal gap between stations, $<135^{\circ}$; nearest station located $<$ $3 \mathrm{~km}$ from earthquake) occurring from 1987 to 2004 (size of dots is proportional to relative magnitude) as listed in Pacific Northwest Seismic Network's catalog, calculated by using stations shown in figure $A$; magnitude of completeness $(\mathrm{Mc}),-0.3$, meaning that

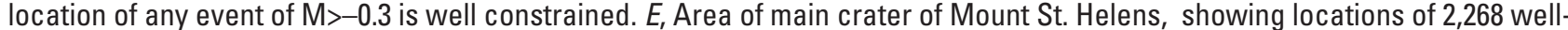
recorded earthquakes (maximum azimuthal gap between stations, $<135^{\circ}$; nearest station located $<3 \mathrm{~km}$ from earthquake) occurring from 1987 to 2004, locations computed using "Mount Rainier-like" configuration of the MSH network shown in figure $C$, so that fewer events met the selection criteria than did the original Pacific Northwest Seismic Network catalog locations shown in figure $D ; M c=0.2$, meaning that location of any event of $M>0,2$ is well constrained. Linear northeast-southwestward epicentral trend which contrasts with narrower, more concentric pattern in figure $D$, is artifact due to suboptimal station distribution. 


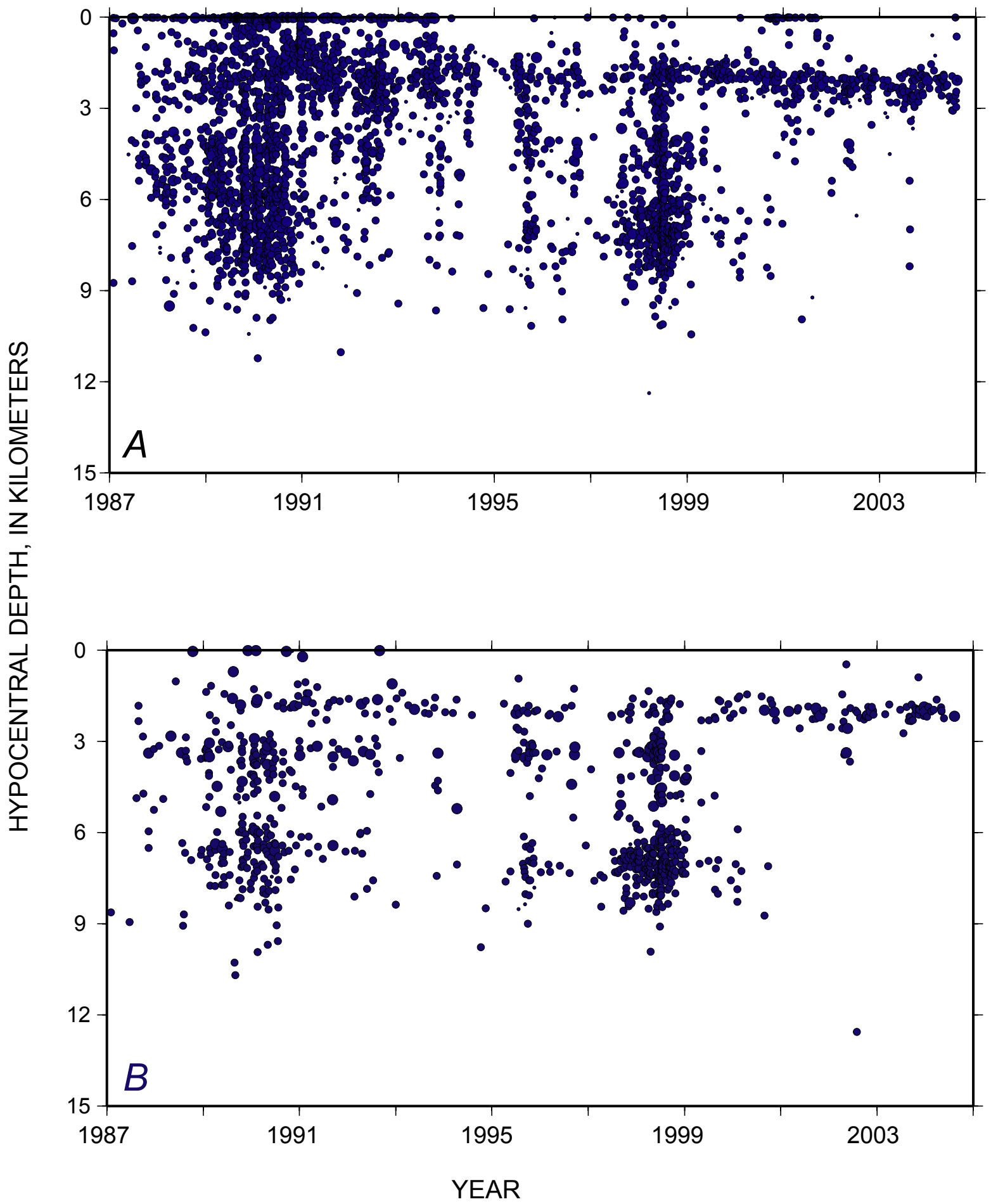

Figure 2. Hypocentral depth versus time for 7,016 earthquakes in the Pacific Northwest Seismic Network's “Rainierlike" network (fig. $1 E)(B)$. Note sharp reduction in number of well-located shallow $(<3 \mathrm{~km}$ deep) events in figure $2 B$, resulting from exclusion of stations located $<3 \mathrm{~km}$ from vent. 
Techniques/instrumentation:

- At least one broadband or strong-motion station located within $5 \mathrm{~km}$ of volcanic center

- Six to eight total seismic stations, at least one with a three-component sensor, located within $20 \mathrm{~km}$, , including two or three located within $5 \mathrm{~km}$, of the volcanic center

Level 4-Detect and accurately locate $M>0$ earthquakes; determine event type; detect and crudely locate seismic tremor; onscale recordings of energetic seismicity on multiple stations; detect and crudely locate very long period events and other very low frequency seismicity.

Techniques/instrumentation:

- At least four broadband stations located within $10 \mathrm{~km}$, including two within $5 \mathrm{~km}$, of the volcanic center

- 12 to 20 total seismic stations, several with a threecomponent sensor, within $20 \mathrm{~km}$ of the volcanic center

- At least one strong-motion station located within 10 $\mathrm{km}$ of the volcanic center

\section{Detection of Changes in Localized Stress Fields}

\section{Capability}

A relatively new field of research in volcano seismology is the investigation of stress-field changes in association with volcanic unrest and (or) eruption. Stress-field changes have been detected during periods of quiescence, unrest, and eruption by changes in fault-plane solutions at Mount St. Helens in 1980-2004 (Moran, 1994; Giampiccolo and others, 1999), Redoubt Volcano in 1989-91 (Sánchez and others, 2004), and Mount Spurr in 1991-92 (Roman and others, 2004)); by changes in $b$-values at Mount Etna (Italy) in 1989 (Vinciguerra, 2002) and Popocatépetl (Mexico) in 2000-1 (NoveloCasanova and others, 2006); and by changes in shear-wavesplitting directions at Ruapehu (New Zealand) in 1998 (Miller and Savage, 2001; Gerst and Savage, 2004). Stress-field changes are commonly interpreted as due to magma intrusion, which creates stress fields that locally "overprint" background stress-field orientations. As such, they can provide important information for assessments as to whether or not seismic swarms will lead to an eruption.

An example of the use of fault-plane solutions is the study by Roman and others (2004), who determined faultplane solutions for earthquakes occurring before, during, and after the eruption of the Crater Peak vent at Mount Spurr in 1992. They reported that the direction of maximum compressive stress beneath Crater Peak became perpendicular to the regional stress field $\sim 7$ months before the eruption, in contrast to a subparallel orientation during background periods. They also characterized the background stress field beneath the summit cone. When seismicity increased beneath Mount Spurr in 2004, the Alaska Volcano Observatory (AVO) was able to compare 2004 fault-plane solutions with those calculated by Roman and others (2004) and determined that the stress field beneath the volcano had not changed significantly (Power and others, 2004a), indicating that an eruption was not imminent. Fault-plane solutions can be calculated in near-real time $(<5$ minutes) if events are constrained by sufficient observations. Moment-tensor solutions, which give a more exact representation of the source, can also be calculated in near-real-time but require three-component data and are generally possible only for larger $(M>3)$ events.

Vinciguerra (2002) used earthquake-catalog data to investigate temporal changes in $b$-values before and during the 1989 eruption of Mount Etna. He reported that $b$-values increased 4-9 months before the eruption, began to decrease 1-4 months before the eruption, plateaued at a relatively low level 1 month before the eruption, and dropped sharply at the onset of eruptive activity. He attributed the $b$-value increases to mechanical hardening (stress increases locally inhibit fracture growth, resulting in numerous small cracks) and the $b$-value decreases to mechanical softening (allowing for fracture growth). He inferred that the large $b$-value decrease accompanying the eruption onset was due to mechanical failure of the fracture system, leading to just a few large cracks (and larger earthquakes). Monitoring of temporal $b$-value changes requires real-time earthquake detection and could conceivably be done with a single station if earthquakes occur in a small volume. Monitoring of spatial $b$-value changes requires real-time earthquake location, which requires multiple stations and can be difficult during vigorous seismic swarms.

Changes in $S$-wave-splitting directions were reported by Miller and Savage (2001) and Gerst and Savage (2004) in association with the 1998 eruption of Ruapehu. They used recordings of local and regional tectonic earthquakes $(M=$ $2-5.5$ ) at 5 - to - 250-km depth and as far as $150 \mathrm{~km}$ from the volcano at broadband stations temporarily installed in 1994, 1998, and 2002 within $10 \mathrm{~km}$ of the summit. In 1994, $S$-wavesplitting directions were perpendicular to the direction of maximum horizontal stress, but in 1998 (after the eruption) $S$-wave-splitting directions had rotated by $\sim 42^{\circ}$ for shallow $(<35 \mathrm{~km})$ earthquakes and by $58-102^{\circ}$ for deep $(55-250 \mathrm{~km})$ earthquakes. By 2002, $S$-wave-splitting directions for shallow earthquakes had returned to the preeruption orientation but were still rotated $58-102^{\circ}$ for deep earthquakes. Results were independent of raypath direction, source mechanism, and dominant frequency. They inferred that the changes in $S$-wavesplitting direction were due to stress changes within the upper crust in a 10 - by $10-\mathrm{km}$ area beneath the station array (all stations show the same change) associated with a $10-\mathrm{km}-$ long dike intruding parallel to the regional direction of maximum horizontal compressive stress. As with fault-plane solutions, $S$-wave-splitting directions can be calculated relatively rapidly if there are sufficient observations. 


\section{Instrumentation}

Fault-plane solutions are most commonly calculated from first-motion data. Source mechanisms can also be determined by moment-tensor inversions of short-period, three-component data (Julian and others, 1998) or broadband data (for example, Chouet and others, 2003). Fault-plane solutions generally are poorly determined with fewer than 7 first motions and are most reliable with 10 or more first motions that are welldistributed around the focal sphere. Amplitude ratios can also be used (Julian and others, 1998; Snoke, 2003), but reliable $S$-wave measurements require three-component sensors. To distinguish between temporal and spatial $b$-value changes, a seismic network must be able to locate events to within $1-\mathrm{km}$ accuracy. Since $b$-values are more accurately determined over a wide range of event magnitudes, at least one broadband seismometer should be installed to enable onscale recording of larger events.

$S$-wave splitting has been detected exclusively on broadband seismometers, although in principle it could be done with short-period three-component sensors. Instruments must be deployed directly above the volume of interest.

\section{Requirements}

Level 1-None.

Level 2-None.

Level 3 - Use fault-plane solutions and $b$-values to determine generalized stress fields near the volcanic center.

Techniques/instrumentation:

- Eight seismic stations located within $20 \mathrm{~km}$ of the volcanic center

Level 4-Detect detailed stress-field changes by calculating well-constrained fault-plane solutions and (or) moment tensors, mapping $b$-values at high spatial resolution, and detecting changes in $S$-wave-splitting directions over time.

Techniques/instrumentation:

- At least five broadband stations located within $20 \mathrm{~km}$ of the volcanic center

- At least 14 total seismic stations located within $20 \mathrm{~km}$ of the volcanic center

\section{Detection of Changes in Seismic Source and (or) Path Over Time}

\section{Capability}

As magma intrudes a volcanic edifice, it theoretically should compress pore spaces, open or close cracks, or other- wise affect the country rock surrounding the conduit. These changes should locally change the bulk-rock properties (density, compressibility, yield strength) of the subsurface and may produce observable changes in seismic velocity, attenuation, or source mechanism over time.

Temporal changes in seismic velocity have been observed to vary over time at several volcanic centers. For example, Gunasekera and others (2003), who inverted traveltimes from local earthquakes at The Geysers (California) to determine three-dimensional velocity models for different time periods, obtained evidence for depletion of a hydrothermal reservoir over a 7-year period. Nishimura and others (2005) used repeated active-source experiments to detect seismic-velocity changes between 1998 and 2003 at Iwate Volcano (Japan). Such changes provide important evidence for processes in active magmatic systems, knowledge that, at a minimum, results in more accurate modeling of magmatic systems and could also signal an impending eruption.

Changes in country rock can also affect scattering properties of the medium, which influence the codas of individual earthquake seismograms. Fehler (1985) reported changes in coda length from preeruptive, through syneruptive, to posteruptive stages at Mount St. Helens in 1981-82, and Londoño and others (1998) reported similar changes before and after the eruptions of Nevado del Ruiz (Colombia) in 1985 and 1989. More recently, researchers have used repeat earthquakes to convincingly demonstrate that variation within certain earthquake families occurs only in the coda, a phenomenon that can be caused only by changes in country rock between the earthquake and the seismometer. Gret and others (2005) inferred that such changes observed at Mount Erebus (Antarctica) likely reflected subtle changes in the uppermost lava-lake system. Novelo-Casanova and others (2006) correlated temporal changes in path attenuation and $b$-value with eruptive activity at Popocatépetl in 2000-1 and inferred that the changes were caused by changes in pore-fluid saturation before, during, and after the eruption.

Finally, changes in the properties of long-period events have been used to infer changes in magmatic systems over time. At Galeras Volcano (Colombia), Gomez and Torres (1997) reported that coda durations increased and dominant frequencies decreased in long-period "tornillo"-type events before dome-damaging explosions. At Kusatsu-Shirane Volcano (Japan), Nakano and others (2003), using the theory of acoustic properties of fluid-filled cracks developed by Kumagai and Chouet (2000), showed with data and modeling that the duration and characteristics of long-period seismic signals change as magmatic fluids flowing through cracks dry out.

\section{Instrumentation}

Instrumentation requirements for tracking changes in seismic source and path over time are similar to those for tracking earthquakes detecting stress-field changes (discussed above for capabilities 1 and 2). 


\section{Requirements}

Level 1 -None.

Level 2-Detect tornillos and occurrence of event families for $M>1$ earthquakes.

Techniques/instrumentation:

- One or two seismic stations located within $10 \mathrm{~km}$ of the volcanic center

Level 3-Detect tornillos and event families for $M>0.5$ earthquakes; detect changes in traveltime; detect broad-scale changes in seismic velocity.

Techniques/instrumentation:

- At least five seismic stations located within $20 \mathrm{~km}$ of the volcanic center

Level 4-Determine detailed source properties of tornillos; detect and locate event families for $M>0$ events; construct three-dimensional velocity models (provided local seismicity is sufficient).

Techniques/instrumentation:

- At least 12 seismic stations located within $20 \mathrm{~km}$ of the volcanic center

\section{Detection and Determination of Source Mechanisms for Very Long Period Events}

\section{Capability}

Since the 1990s, broadband sensors have been installed at an increasing number of volcanoes worldwide, lowering the limit of detectable seismic frequencies from 0.5 to $0.01-0.03$ $\mathrm{Hz}$. One result of these deployments has been the recording of very long period events at such volcanic systems as Popocatépetl (Arciniega-Ceballos and others, 1999; Chouet and others, 2005; Auger and others, 2006), Merapi (Philippines) (Hidayat and others, 2000), Miyakejima (Japan) (Kumagai and others, 2001; Kobayashi and others, 2003), Mammoth Mountain (California) (Hill and others, 2002), Mount Bandai (Japan) (Nishimura and others, 2003), Stromboli (Italy) (for example, Chouet and others, 2003), Mount Erebus (Aster and others, 2003), Mount Asama (Japan) (Ohminato and others, 2006), and Mount St. Helens (Waite and others, 2008). Very long period tremor has also been observed at Stromboli (De Lauro and others, 2005). Models have shown that such events can be caused by movement of a magmatic mass at moderate accelerations or by inflation of a sill or dike (for example, Chouet and others, 2003). With sufficient numbers of broadband sensors, all elements of the moment tensor for movements within this frequency range can be completely determined, yielding the location, dimensions, and volume of the source, as well as possible movement of the source over time (Chouet and others, 2003). Very long period events have been recorded in association with eruptions and during noneruptive periods (for example, at Mammoth Mountain (Hill and others, 2002)). Although it remains to be seen whether very long period events are a robust precursor to eruptive activity, they clearly constitute a type of seismic event that should be locatable by level 4 networks and detectable by level 3 networks.

\section{Instrumentation}

Very long period events can be detected with just one or two broadband sensors, although the sensors must be placed fairly close $(<5 \mathrm{~km})$ to the source (B.A. Chouet, written commun., 2005). To locate these events requires five or six stations located within 5 kilometers of the volcanic center. More broadband stations are required to completely determine all elements of the moment-tensor matrix as well as the location and (or) relative movement of the source.

\section{Requirements}

Level 1-None.

Level 2-None.

Level 3-Detect very long period events.

Techniques/instrumentation:

- At least one broadband station located within $5 \mathrm{~km}$ of the volcanic center

Level 4-Detect and locate very long period events and track relative movement of the source.

Techniques/instrumentation:

- At least five broadband stations located within $5 \mathrm{~km}$ of the volcanic center

\section{Explosion Detection and Monitoring}

\section{Capability}

Explosions can produce seismic signals that are not easily distinguishable from rockfalls or seismic tremor; however, explosions commonly produce infrasonic signals (atmospheric "sound" waves in the range $1-25 \mathrm{~Hz}$ ) that are unique and easily interpretable as explosions (for example, Johnson and others, 2004). As a result, infrasonic sensors are increasingly deployed at active volcanoes and can be critical for rapid identification of an explosive event.

Infrasonic recordings have been made at many erupting volcanoes since the 1990s, including Arenal (Costa Rica) (Garcés and others, 1998; Hagerty and others, 2000), Karymsky (Russia) (Johnson and Lees, 2000; Lees and others, 
2004), Sakurajima (Japan) (Garcés and others, 1999), Mount Erebus (Rowe and others, 2000), Sangay (Ecuador) (Johnson and Lees, 2000), Shishaldin (Caplan-Auerbach and McNutt, 2003), Kîlauea (Garcés and others, 2003), Fuego (Guatemala) (Johnson and others, 2004), Villarrica (Chile) (Johnson and others, 2004), and Mount St. Helens (Matoza and others, 2007; Moran and others, in press b). At Shishaldin, CaplanAuerbach and McNutt (2003) reported that pulses recorded on a pressure sensor collocated with a short-period seismometer began to occur 12 hours before a subplinian explosion in 1999. The pulses, which they inferred to be caused by gas release from rising magma, progressively increased in amplitude and occurred closer together in time until they merged into a continuous signal just before the eruption. Seismic tremor amplitudes also slowly increased over this period (Thompson and others, 2002), though not in a manner suggestive of an impending subplinian explosion. The eruption itself was marked by several low-frequency infrasonic pulses. In hindsight, the pressure data could have enabled scientists to more precisely forecast the onset of explosive activity.

At Mount St. Helens in 2004-5, Moran and others (in press b) reported that two microphones at a single site greatly improved the ability to distinguish between wind gusts and infrasonic signals. They also noted that infrasonic sensors, if sufficiently isolated from the ground, can be critical for explosion detection when seismic stations are saturated by intense seismicity. Along with Matoza and others (2007), they also noted that explosions produced varying degrees of seismic and infrasonic energy, a phenomenon reported at several other volcanoes by Johnson and Aster (2005). The implication of this observation is that detection of relatively minor (but still hazardous to aircraft) explosions is not guaranteed by either an infrasonic or seismic array, but with both types of sensors the odds are greatly improved.

\section{Instrumentation}

Current practice is to collocate infrasonic instruments (microphones, pressure transducers, or other acoustic sensors) with seismometers at actively erupting volcanoes to aid in distinguishing between infrasonic signals and those due to coseismic shaking of infrasonic instruments. Ideally, multiple infrasonic sensors or sensor arrays should be deployed at a single site, greatly improving the signal-to-noise ratio and allowing for possible location of infrasonic sources (Matoza and others, 2007; Moran and others, in press b). At least one infrasonic site should be located reasonably close to $(<10 \mathrm{~km}$ from) an active volcanic center to provide the earliest possible warning and detect small-amplitude infrasonic signals. Infrasonic sensors are not required at most volcanoes that are not restless or erupting because infrasound has not been proved to be a useful monitoring technique for detecting precursory unrest. One exception to this recommendation is at especially remote volcanoes, such as those in the Aleutian Islands, where deployment of infrasonic sensors in rapid-response mode is in most circumstances impractical or impossible. In such places, infrasonic sensors should be installed in concert with other monitoring equipment.

\section{Requirements}

Level 1-None.

Level 2-None.

Level 3-None, except at remote volcanoes where rapid deployment is impractical most of the year (for example, in the Aleutian or Mariana Islands).

Level 4-Detect explosions and possible infrasonic precursors to explosions at restless and (or) frequently active volcanoes.

Techniques/instrumentation:

- At least two infrasonic stations (with at least two sensors per station) collocated with seismic stations within $10 \mathrm{~km}$ of the volcanic center

\section{Summary-Recommendations for Level 1-4 Networks}

Level 1-Locate a total of five seismic stations within 200 $\mathrm{km}$, including two within $50 \mathrm{~km}$, of the volcanic center.

Level 2-Locate a total of five seismic stations within $50 \mathrm{~km}$, including two within $10 \mathrm{~km}$, of the volcanic center.

Level 3-Locate six to eight seismic stations within $20 \mathrm{~km}$ of the volcanic center, including two or three stations with at least one three-component sensor, and at least 1 broadband station, within $5 \mathrm{~km}$.

Level 4-Locate 12 to 20 seismic stations within $20 \mathrm{~km}$ of the volcanic center, including at least six broadband stations, as many as possible within $5 \mathrm{~km}$; at least one strong-motion station; and at least two infrasonic stations (with at least two infrasonic sensors per station) at erupting, restless, and (or) frequently active remote volcanic centers.

Cache - There should be three to four infrasonic sensors and enough short-period and broadband stations in a ready-todeploy condition to rapidly bring a level 2 network up to level 4 in the event of volcanic unrest. In addition, infrastructure should be built for establishing one remote digital acquisition system (including discriminators, digitizers, and so on). 


\section{Deformation Monitoring}

\section{Introduction}

Ground displacement at a volcano is frequently associated with magmatic and volcanic activity, usually as a result of magma accumulation or migration beneath the Earth's surface. Characterization of surface deformation provides important constraints on the potential for future volcanic activity, especially in combination with seismicity, gas emissions, and other indicators. In our view, three primary capabilities are required of deformation-monitoring networks on active volcanoes: (1) detection of changes in ground-displacement patterns in nearreal time, (2) location of buried sources of surface deformation in three dimensions and estimation of their magnitude and geometry, and (3) distinction of magmatic from nonmagmatic deformation. In this section, we propose a strategy for monitoring surface deformation at U.S. volcanoes, with the goal of achieving the capabilities listed above. We begin with a description of the various types of instruments and techniques useful for measuring ground displacements at volcanoes. This description is needed because of the range of techniques that can be used to measure and detect surface deformation (including surface installations, equipment installed in boreholes, and satellite-based technology), each with its own spatiotemporal scale. We then describe and justify the desired capabilities for deformation-monitoring networks on volcanoes of different threat levels, listing the equipment needed for each capability according to the level of monitoring desired (Ewert and others, 2005). For additional background information on deformation monitoring, instrumentation, and methods, see the reports by Dzurisin $(2000,2003,2007)$.

\section{Deformation-Monitoring Equipment}

A wide variety of techniques and instrument types have been applied to the study of ground displacements at volcanoes. Experience has shown that no single deformation-

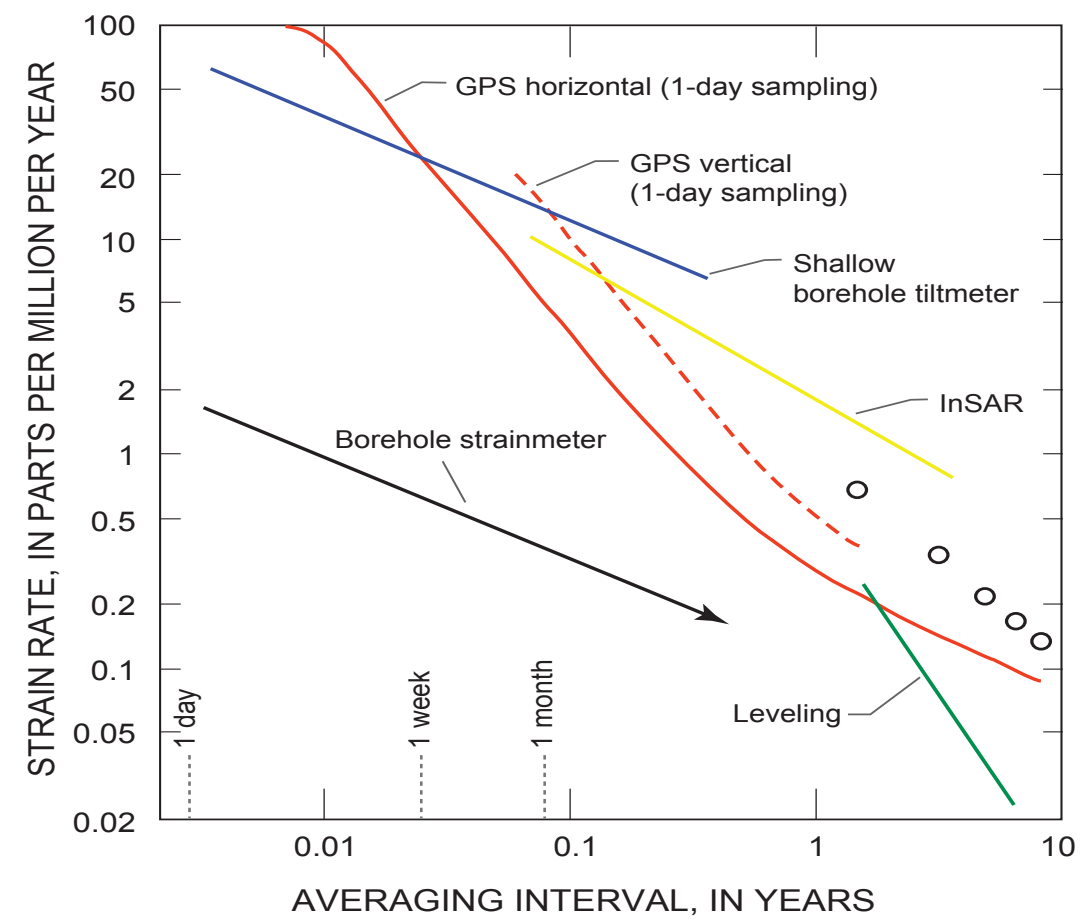

Figure 3. Strain rate versus averaging interval for types of deformation monitoring described in this report. Baselines of $8 \mathrm{~km}$ were assumed for GPS and InSAR. Note that borehole strainmeters provide best measurements over time scales of minutes to days, whereas GPS (circles) and leveling surveys and InSAR provide best measurements over time scales of months to years. Adapted from Dzurisin (2007, fig. 1.23). 
monitoring technique is adequate to detect and track the entire range of ground-displacement patterns that occur at restless volcanoes, primarily because some forms of unrest develop over years to decades, while others develop over hours to days (fig. 3). Similarly, the magnitude of surface deformation associated with volcanic unrest varies widely. Simply put, no single instrument or measurement technique can detect and characterize all aspects of surface deformation at volcanoes. Therefore, deformation-monitoring strategies should consist of a range of techniques and instrument types, including continuously recording Global Positioning System (GPS) stations, GPS surveys, borehole tiltmeters, continuous- and survey-mode gravity measurements, precise leveling surveys, and interferometric-synthetic-aperture-radar (InSAR) measurements. We also discuss the utility of borehole strainmeters for monitoring deformation, although we do not specifically recommend their deployment as part of standard NVEWS networks.

In selecting the instrumentation mixes for deformationmonitoring networks, we attempted to maximize the flexibility of instrument types, while minimizing their expense and numbers. Thus, we do not recommend the use of several well-known deformation-monitoring techniques, for example, extensometers (for measuring strains over distances of a few meters), which are relatively inexpensive and have an excellent record of success, including at Mount St. Helens (Washington) during a dome-building eruption in 1985 (Iwatsubo and others, 1992) and at eruptions of Piton de la Fournaise (Réunion Island) (Peltier and others, 2006). Borehole tiltmeters, however, which are more broadly used in routine realtime monitoring networks, should be able to detect the same types of displacements. Future developments in instrumentation will affect the strategies and technologies used to measure deformation at active volcanoes, and should be incorporated into deformation-monitoring networks whenever practical.

\section{Global Positioning System}

In the late 1980s, GPS instruments became a valuable means for measuring deformation of the Earth's surface, gradually replacing such older techniques as electronic distance measurement and triangulation. The primary advantage of GPS over all other deformation-monitoring methods is its ability to simultaneously measure horizontal and vertical positions with a precision of a few millimeters. GPS instruments are used in either continuous or survey mode. Continuous-mode GPS stations consist of a permanently installed GPS receiver and antenna at one site to track the position of that site over time, providing excellent temporal resolution of deformation. In survey mode, a GPS antenna on a tripod is set over a bench mark for a short period ( $\sim 1-3$ days) and then moved to other sites as needed; repeat occupations of the same bench marks provide information about ground motion at each site between surveys. GPS surveys give better spatial coverage than continuous-mode GPS stations because many sites can be measured with only a few GPS receivers; however, temporal resolution is generally poor.

GPS is widely used to monitor active volcanic systems. At Kīlauea and Mauna Loa volcanoes (Hawai i), for example, the Hawaiian Volcano Observatory (HVO) has installed more than 40 continuous-mode GPS stations, supplemented by more than 200 sites that are periodically occupied during semiannual GPS surveys. This combination of methods provides good temporal and spatial resolution of the surface deformation associated with these two volcanic systems. For example, GPS detected the onset of inflation at Mauna Loa in 2002 (Miklius and Cervelli, 2003) and has been used to map aseismic-slip events on Kīlauea's south flank (Cervelli and others, 2002b), as well as dike intrusions and other magmatictectonic activity (Owen and others, 1995; Owen and others, 2000a, 2000b; Cervelli and others, 2002a; Brooks and others, 2006; Segall and others, 2006).

Continuous-mode GPS stations are most commonly used to record daily average positions; however, recent research shows that GPS can also be used for near-real-time monitoring. LaHusen and others (2008) used single-frequency GPS receivers in kinematic mode to record dome growth at Mount St. Helens, with positions of $\sim 1-\mathrm{cm}$ accuracy determined in near-real time every 20 minutes, using 10 -s-interval data. High-rate $(1 \mathrm{~Hz})$ GPS has recently shown promise for measuring rapid changes in ground displacement, for example, in studies of earthquakes in Alaska (Larson and others, 2003), Japan (Miyazaki and others, 2004), and California (Ji and others, 2004). Langbein (2006) tested various methods of highrate GPS and reported that instantaneous offsets of $\sim 1 \mathrm{~cm}$ can be measured in some situations. Further study with various types of GPS software and methods should improve the utility of this technique. Though still experimental, near-real-time, high-rate GPS will likely become an operational tool within a few years, by which time it should be included in volcanomonitoring strategies. Incorporating such methods will not require new equipment, only the development of new software and reprogramming of existing GPS receivers.

GPS instruments should form the backbone of nearreal-time deformation-monitoring networks. However, GPS antennas can be affected by icing and other climatic conditions, leading to erroneous measurements or data gaps. In addition, models of subsurface deformation sources based on GPS alone can result in ambiguous solutions. GPS instruments must therefore be supplemented by other instrument types to maintain adequate monitoring levels during extreme weather conditions and to better interpret any deformation anomalies.

\section{Borehole Tiltmeters}

Ground tilt has proved to be a remarkably sensitive indicator of shallow, short-term volcanic processes. As a result, measurements of ground tilt have been used in volcano-monitoring networks for almost a century. Thomas A. Jaggar, the founder of $\mathrm{HVO}$, first observed tilt associated with volcanic 
activity at Kîlauea in 1912 (Kinoshita and others, 1974). Tilt measurements at Mount St. Helens in the 1980s from continuously recording surface instruments were an integral part of the successful predictions of 1980-86 dome-building eruptions (Dzurisin and others, 1983). A good example of a modern-day tilt network is the 20-station borehole-tiltmeter network used by HVO at Kīlauea and Mauna Loa volcanoes. Each instrument produces one data sample per minute, which is sent in near-real time to HVO. Near-real-time tilt data are critical for detecting transient deformation that occurs over periods of seconds to hours, and tilt is one of the few geodetic monitoring techniques that does not require significant processing or calibration.

A principal drawback to tiltmeters is that they tend to drift over time scales of weeks to months and so cannot be used to measure long-term deformation trends. In addition, ground tilt can be caused by variations in environmental conditions, particularly periods of extended rainfall (M. Lisowski, written commun., 2006) and diurnal temperature fluctuations (Dzurisin, 1992). Thus, shallow (2-3 m deep) borehole instruments are preferable to surface-mounted tiltmeters because burial even to just a few meters below the surface dampens sensitivity to environmental effects.

\section{Microgravity}

Gravity changes are used to characterize vertical deformation and subsurface mass change. As the Earth's surface moves farther from or closer to its center of mass, gravity will correspondingly decrease or increase. Similarly, increases or decreases in mass beneath a gravity-measurement site will cause corresponding increases or decreases in gravity. Gravity alone, however, cannot distinguish between mass variations and vertical displacements. For example, before the explosive eruption of Poás Volcano (Costa Rica) in 1989, Rymer and Brown (1989) attributed observed variations in gravity to preeruption magma movement. However, Tilling (1989) noted that the absence of sufficient elevation controls made their interpretations nonunique and difficult to substantiate. Coupling gravity with vertical-deformation data removes this ambiguity and allows for estimates of the density of a subsurface source of mass increase or decrease.

Owing largely to logistic difficulties, gravity has not been used as frequently as other deformation-monitoring techniques at volcanoes. At Long Valley caldera (California), uplift since 1983 has been ascribed either to the accumulation of hydrothermal fluids or magma (for example, Hill and others, 1985; Langbein and others, 1993). Combined gravity and deformation surveys suggested a source density of $2.7 \mathrm{~kg} / \mathrm{m}^{3}$, consistent with magma, not water or gas, as the cause of the volume change (Battaglia and others, 2003). Conversely, gravity measurements at Campi Flegrei caldera (Italy) implied that hydrothermal activity, not magma, drove uplift and seismicity in 1980-84 (Battaglia and others, 2006). At Askja Volcano (Iceland), gravity surveys over 2 decades indicated that the deflation there was driven by a combination of magma cooling and crystallization, and magma drainage to deeper levels (de Zeeuw-van Dalfsen and others, 2004).

These examples illustrate the utility of gravity surveys, some with decades between measurements. Continuous gravity recording, in contrast, can provide evidence of short-term changes in elevation, subsurface mass, and fluid flow. A continuously recording gravimeter in operation at Mount Vesuvius (Italy) since 1986 has led to recognition of the correlations between seismicity and gravity (Berrino and others, 2006). At Mount Etna (Italy), Branca and others (2003) showed that an increase in background seismic noise levels was followed $\sim 2.5$ hours later by a rapid gravity decrease before the start of an eruption in October 2002. An 8-day continuous gravity and seismic experiment at Yellowstone National Park (Wyoming) in 2002 correlated fluctuations in microseismicity with timeseries of gravity rms errors (Tikku and others, 2006), possibly related to subsurface fluid flow due to active hydrothermal processes. Continuous gravity measurements collected at Merapi Volcano (Philippines) during eruptions in the mid-1990s showed similar correlations between gravity and volcanic activity, leading Jousset and others (2000) to conclude that the gravity variations were caused by changes in pressure within the magma reservoir at depth.

The principal utility of gravity measurements is to identify changes in mass flux at depth. Thus, continuous gravity monitoring is best used at such volcanic centers as Long Valley caldera, Yellowstone caldera, Mount St. Helens, Kîlauea, and Mauna Loa that are erupting or frequently restless. Gravity surveys are a good means for monitoring baseline trends on year-long time scales but may not be logistically feasible at more remote volcanoes.

\section{Precise Leveling}

Precise leveling is generally the most accurate method for characterizing vertical surface deformation. During a leveling survey, the heights of a series of permanent bench marks are measured and compared with previously collected data. The method is most practical on lower-relief volcanoes traversed by roads or trails, where crews of three to five people can complete a 3 to $5-\mathrm{km}$-long leveling line in a single day. The time and personnel requirements make leveling one of the more expensive methods for measuring surface deformation, but the data frequently prove critical for interpreting volcanic processes. Leveling can also be used to measure vertical deformation at gravity survey stations, which is needed to correct gravity results for height changes. Although GPS data can be used for height corrections, for example, at Long Valley caldera (Battaglia and others, 1999; Battaglia and others, 2003), leveling provides more accurate results.

Leveling surveys have led to the discovery of surface deformation at several volcanoes. Dzurisin and others (1991) reported that the summit of Medicine Lake (California) had subsided $\sim 30 \mathrm{~cm}$ between 1954 and 1989. Subsequent sur- 
veys showed that the deformation continued at the same rate through 1999 (Dzurisin and others, 2002; Poland and others, 2006). At Yellowstone, leveling was the primary deformationmonitoring tool for many decades (Dzurisin and others, 1999).

A primary limitation of leveling is that it provides deformation information only along a profile. Deformation occurs in three dimensions, however, and other data are needed for a more complete picture of the deformation field. Nevertheless, leveling remains an important deformation-monitoring method at volcanoes where low deformation rates cannot be resolved by other methods.

\section{Interferometric Synthetic Aperture Radar}

InSAR is a technique that utilizes two satellite radar images of the same geographic area acquired from the same orbital point at different times. The two radar scenes are interfered through software to determine the phase shift caused by ground displacement (Zebker and others, 2000). InSAR, which is sensitive to ground displacements of $\sim 1 \mathrm{~cm}$, was first applied to the study of surface deformation at volcanoes in the early 1990s (Massonnet and others, 1995; Rosen and others, 1996) and is still a relatively new tool for volcano monitoring.

InSAR has two primary advantages over other deformation-monitoring methods: (1) it provides high spatial resolution along swaths tens to hundreds of kilometers wide, and (2) it requires no ground-based instrumentation. These two advantages combine to make InSAR particularly useful for detecting surface deformation at poorly monitored or inaccessible volcanoes. For example, South Sister (Oregon) was largely unmonitored before 2001 because it showed no obvious signs of unrest, such as seismic activity or gas emissions. However, InSAR data obtained in 2001 indicated that an area west of the volcano had been inflating since 1997 at about 3 $\mathrm{cm} / \mathrm{yr}$, probably owing to magma accumulation below the surface (Wicks and others, 2002). Similarly, InSAR observations of Mount Peulik (Alaska) revealed significant uplift beginning 2 years before a seismic swarm (Lu and others, 2002). In early 2006 at Kîlauea volcano, continuous GPS and tilt monitoring detected an increase in the inflation rate of the summit caldera but did not have the spatial density to resolve the displacement source, whereas InSAR data provided a much clearer view of the activity, indicating a source at 3 to $4-\mathrm{km}$ depth beneath the southern part of the caldera.

InSAR also has some significant drawbacks. In its present state of development, InSAR is not an operational tool for monitoring restless or erupting volcanoes. Present limitations in satellite availability and tasking priorities create long intervals between repeat image acquisitions, limiting the role of InSAR to supporting long-term characterization of surface deformation, similar to other survey-mode measurements.

For example, the InSAR results at Kîlauea in 2006 mentioned above were obtained months after the onset of inflation, owing to delays in data availability, ordering, and shipping. Once the agencies responsible for synthetic aperture radar data collec- tion gain more experience in data distribution, obtaining data within hours of image acquisition may be possible, increasing the utility of InSAR as a rapid-response tool. Another drawback is that unlike GPS, InSAR is sensitive only to one component of the three-dimensional displacement field, specifically the component oriented along the satellite's line-of-sight. Finally, usable interferograms are generally difficult to obtain in rugged, ice-covered, and (or) heavily vegetated terrains, which are common in volcanic areas.

\section{Borehole Strainmeters}

At present, strainmeters are the most sensitive instruments for monitoring deformation associated with volcanic activity. Installation involves cementing a strainmeter inside a hundreds-of-meters-deep borehole to insulate the sensor from surface noise. As the Earth changes in size and shape owing, for example, to magma accumulation in a nearby subsurface reservoir, the resulting strains will be detected by the borehole strainmeter.

Borehole-strainmeter deployments date back to the early 1970s, when Sacks-Evertson dilatometers were installed to measure deformation associated with earthquakes in Japan (Sacks and others, 1971). In the late 1970s, several strainmeters that had been installed in Iceland to monitor seismicity incidentally recorded deformation associated with the eruptions of nearby Hekla volcano, including the only deformation precursor to the 1991 eruption (Linde and others, 1993). Strainmeters also proved critical for detecting a strain transient at Long Valley caldera that was triggered by the 1993 Landers earthquake $\sim 400 \mathrm{~km}$ to the south (Hill and others, 1995). Although local seismicity was also triggered, cumulative seismic energy release was two orders of magnitude smaller than that of the strain transient. In addition, no surface deformation was measurable, meaning that no deformation anomalies would have been detected without the borehole strain data. Hill and others (1995) posited that the signal may have resulted from a deep dike intrusion beneath the caldera.

On the basis of these and other studies, boreholestrainmeter networks have been installed in Hawai' $i$ and Montserrat with the goal of measuring subtle, small-scale transients that might indicate impending changes in volcanic activity. The four Hawai`i instruments, which were installed at Mauna Loa and Kîlauea, have detected a variety of signals. A compressional-strain transient in 2001 at Kīlauea correlated with a decrease in water level in the same borehole, suggesting that poroelasticity and thermal pressurization are unimportant effects within the volcano and that surface deformation at Kîlauea is not triggered by pressurization of the hydrothermal system (Hurwitz and Johnston, 2003). Four strainmeters in Montserrat are part of the Caribbean Andesite Lava Island Precision Seismo-geodetic Observatory (CALIPSO) project, which includes a suite of borehole and surface equipment intended to monitor activity at Soufrière Hills volcano. Mattioli and others (2004) described the installation of the 
equipment, as well as ultra-long-period strainmeter and seismometer signals that spanned the 2003 lava-dome collapse at the volcano.

The primary drawback to borehole strainmeters is their high cost (for both instrument and installation) and the logistic complexity of the installation process. Furthermore, repair of a strainmeter after installation is nearly impossible. Also, like tiltmeters, strainmeters have poor sensitivity to long-term (months to years) deformation (fig. 3). For these reasons, we do not make any specific recommendations for the use of borehole strainmeters in NVEWS networks. The capabilities enabled by borehole instrumentation and their potential role in NVEWS networks are more fully discussed in the section below entitled "Boreholes and Borehole Instrumentation."

\section{Deformation Monitoring—Required Capabilities}

The three capabilities required of NVEWS deformation monitoring networks are (1) detection of changes in displacement patterns in near-real time, (2) location of buried sources of deformation in three dimensions and estimation of their magnitude and geometry, and (3) distinction of magmatic from nonmagmatic deformation. We note capabilities 2 and 3 are intimately linked because the volume and depth of a source must first be estimated to infer its origin. Nevertheless, we describe these three capabilities separately for clarity and provide justification based on examples from volcanoes around the world.

Below, we make recommendations for specific numbers of instruments required to enable each capability. The GPS instrumentation recommendations are partly based on numerical simulations of hypothetical surface-deformation patterns. Given the diversity of volcano type, size, eruptive behavior, local geography, accessibility, and climate, the instrument mix and deployment strategy should be customized to each volcanic system. Accordingly, we give ranges of instrument numbers and use the phrase "if practical" for several techniques. (For example, it is impractical to level over the summit of Mount Rainier, despite the importance of accurate vertical surface-deformation measurements at that volcano.)

Our recommendations should not be taken as the final word on deformation monitoring at volcanoes but, instead, as a proposal based on current technology and understanding of volcanic processes that will evolve with future discoveries and technological developments. Particularly since the 1980s, deformation networks have been established at many volcanoes worldwide to aid in the characterization and forecasting of volcanic activity. One of the most ambitious recent efforts is the volcano component of the National Science Foundation's Plate Boundary Observatory (PBO), which began installing continuous-mode GPS stations and borehole strainmeters across the Western United States in 2003, including instrument clusters at several volcanic centers. As of 2007, PBO had established or augmented continuous-mode GPS networks at Yellowstone and Long Valley calderas and at Mount St.
Helens, Augustine Volcano (Alaska), and Akutan Volcano (Alaska). Results from these clusters and other volcano-monitoring networks around the world provide important insights into volcano dynamics and are likely to influence both the equipment and strategies used in deformation monitoring at U.S. volcanoes.

\section{Detection of Displacement-Pattern Changes}

\section{Capability}

Although the detection of displacement-pattern changes may be the most important capability of a deformation-monitoring network, it is a challenging goal because of the wide range of time scales over which precursory changes can occur. Precursory deformation has occurred within as little as 30 minutes at Hekla in 1991 (Linde and others, 1993)) to several hours at Mount Etna in 2002 (Aloisi and others, 2003). Deformation measurements were used at Mount St. Helens to issue successful predictions days to weeks before more than a dozen dome-building eruptions during 1980-86 (Swanson and others, 1983; Chadwick and others, 1988; Chadwick and Swanson, 1989). At the other extreme, anomalous surface deformation at Augustine was recognized several months before the onset of eruptive activity there in 2006 (Cervelli and others, 2006), and InSAR-detected deformation at Three Sisters (Wicks and others, 2002) could represent an example of decades-long precursory deformation. Thus, the capability to detect both shortand long-term deformation-field changes is critical.

In addition to detecting surface deformation precursory to an eruption, monitoring the stability of volcanoes is another critical capability of deformation-monitoring networks. At many large stratovolcanoes, for example, Mount Rainier, flank collapses and landslides are significant geologic hazards (Reid and others, 2001). One of the most famous examples of edifice instability is the large flank collapse that initiated the May 18, 1980, eruption of Mount St. Helens. Deformation monitoring had detected a bulge on the north flank of the mountain in April 1980 that was expanding by several meters per day (Lipman and others, 1981). Given that flank collapses can happen at any time during a period of volcanic unrest, the capability to assess edifice stability is critical.

\section{Instrumentation}

Near-real-time data should have a latency of no more than a few minutes, which at present is best achieved with borehole tiltmeters. Continuous gravimeter and strainmeter operations can also provide sensitive real-time grounddisplacement measurements, although gravimeters must be collocated with a continuous-mode GPS station for elevation control. As discussed above, high-rate GPS shows promise for near-real-time detection of changes in the deformation field. Once developed to a level suitable for operational use, high-rate GPS should be exploited as a tool for detecting rapid 
deformation transients. High-rate GPS would provide grounddisplacement data that are independent of tiltmeter records and of higher accuracy, given a sufficiently large displacement signal, because GPS enables measurement of three-dimensional position changes. However, GPS receivers are vulnerable to ice and snow burial at high-elevation sites, and so tiltmeters should be deployed in concert with GPS receivers to ensure year-round detection capability. Periodic InSAR measurements and GPS and (or) leveling surveys should be performed to provide longer-term measurements with higher spatial resolution than is possible with continuous-mode GPS stations.

\section{Requirements}

Level 1-Establish a baseline for future deformation monitoring.

Techniques/equipment:

- One-time InSAR measurements or GPS or leveling surveys

Level 2-Use repeat monitoring to measure background displacement patterns.

Techniques/equipment:

- InSAR measurements or GPS or leveling surveys, repeated so as to detect surface deformation over time scales of $1-10$ years

- One continuous-mode GPS station

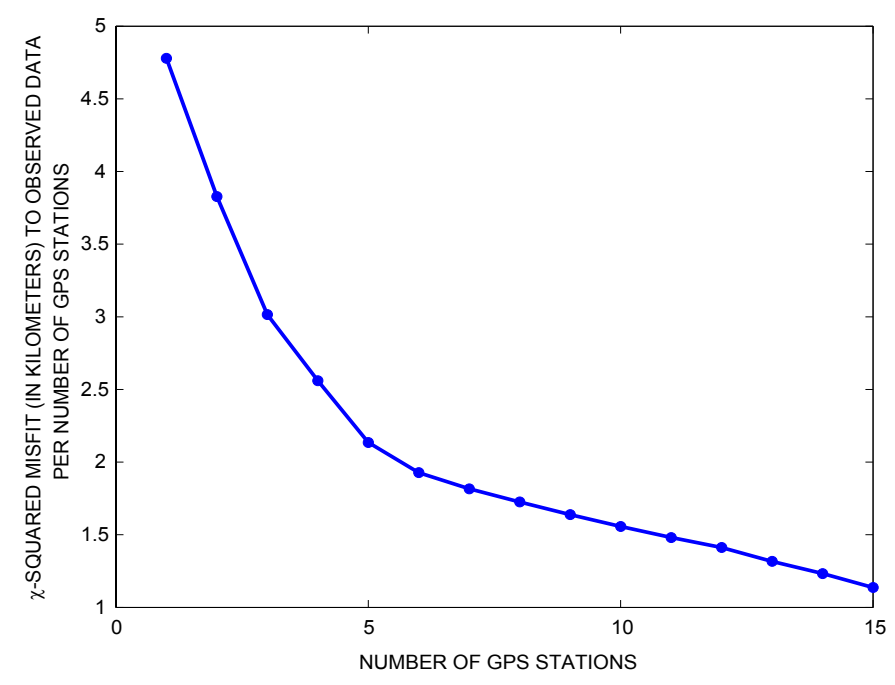

Figure 4. Sensitivity plot illustrating uncertainty in geodeticmodel parameters (for example, depth or volume change in a subsurface source) versus number of GPS stations. More stations provide better constraints on model parameters, and more than 15 GPS stations are needed to accurately determine, for example, source depth or strength.
Level 3-Detect changes in the deformation field with a latency of no more than a few days.

Techniques/instrumentation:

- Two or three continuous-mode GPS stations located within 5 to $10 \mathrm{~km}$ of the volcanic center

- Two to four borehole tiltmeters located within 5 to 10 $\mathrm{km}$ of the volcanic center

Level 4-Detect changes in the deformation field with a latency of no more than a few hours.

Techniques/instrumentation:

- Eight continuous-mode GPS stations, at least five of which are located within 5 to $10 \mathrm{~km}$ of the volcanic center

- 5 to 10 borehole tiltmeters located within 5 to $10 \mathrm{~km}$ of the volcanic center

- One continuous gravimeter (if conditions are appropriate) located within $5 \mathrm{~km}$ of the volcanic center, collocated with a continuous-mode GPS station for elevation control

\section{Location of Deformation Sources and Estimation of Source Magnitude and Geometry}

\section{Capability}

Another primary goal of deformation monitoring at active volcanoes is to map the geometry, strength (generally expressed as change in either volume or pressure), and threedimensional position of magma bodies. Although these parameters are independent, they cannot be uniquely determined if the spatial resolution of deformation data is too low. For example, Delaney and McTigue (1994) showed that volumechange estimates depend heavily on reservoir geometry. This is illustrated by deformation measurements indicating subsidence at Medicine Lake Volcano (Dzurisin and others, 2002), which could be equally well fitted by either a point source of volume change (Mogi, 1958) or a horizontal opening-mode dislocation approximating a sill (Okada, 1985). The sill-like model yielded a volume change 30 percent lower than the point-source model (Dzurisin and others, 2002). Source depth similarly depends on geometry. Dieterich and Decker (1975) used finite-element models to show that different reservoir geometries produce different patterns of horizontal and vertical surface deformation. Any deformation-monitoring network must therefore have the capability of measuring different components and spatial scales of ground displacements to distinguish among competing models.

Estimates of source strength are important to assessments of future activity, especially at restless or active volcanoes. For example, at Soufrière Hills Volcano, GPS measurements have detected time-varying behavior of a deformation source 5 to $6 \mathrm{~km}$ beneath the volcano (Wadge and others, 2006). 
During eruptive periods, the source contracts as flux out of the reservoir to the surface exceeds the supply of magma to the reservoir from deeper regions; and during eruptive pauses, the reservoir inflates as magma accumulates. Rates of volume change are therefore useful as an indicator of the likely future course of an eruption.

The ability to distinguish between one and multiple deformation sources is also critical for inferring source location, depth, and strength. For example, surface deformation at Mauna Loa has been modeled as due to a combination of two sources (a point source and a dike), resulting in a complex deformation field (Amelung and others, 2007). The displacement patterns due to these two sources must be separated to most accurately assess the status of an eruption and its likely future course. If the deformation-monitoring network were too small or not designed to distinguish between the effects of these two competing sources, interpretations of surface-deformation data would be unreliable and could lead to incorrect interpretations of volcanic unrest.

\section{Instrumentation}

For the best sensitivity to source location, geometry, and strength, deformation should be measured over a range of distances from the source. These measurements can be done in near-real time with a network of continuous-mode GPS instruments and borehole tiltmeters, or over longer time scales using InSAR and (or) GPS surveys. Both strategies should be used because InSAR measurements and GPS surveys provide the best spatial resolution, whereas borehole tilt and continuousmode GPS provide the best temporal resolution. Tilt is especially valuable for detecting changes over minutes to hours in shallow magma sources, and arrays of borehole tiltmeters have been used independently of other data types to model source depths and volume changes at Kïlauea (Miklius and Cervelli, 2003).

To formalize a recommendation for numbers of nearreal-time continuous-mode GPS instruments, we performed numerical simulations of the sensitivity of the density of continuous-mode GPS stations to a buried inflation source (fig. 4). In our hypothetical scenario, we assumed a source at 2-km depth typical of the shallowest magma-accumulation zones at several volcanoes (Bransdóttir and others, 1997; Iwashita and others, 2005; Pagli and others, 2006; Yun and others, 2006). Synthetic three-component surface displacements were forward-calculated for a point-source model (Mogi, 1958), assuming a modest volumetric inflation of $0.001 \mathrm{~km}^{3}$. Gaussian random noise was added to the synthetic data by assuming a standard deviation of $2 \mathrm{~mm}$ in the horizontal components and of $6 \mathrm{~mm}$ in the vertical component (typical of continuousmode GPS data).

We employed a Monte Carlo algorithm to run multiple simulations with different station distributions. A GPS network was constructed by randomly locating stations around the volcanic edifice, with 95 percent of stations within $11 \mathrm{~km}$ of the volcano's summit (beneath which the source is located) and a reference station at a distance of $30 \mathrm{~km}$. A total of 1,000 simulations were performed for a given number of stations, with each simulation using a unique station distribution. The synthetic data were inverted by using a nonlinear minimization algorithm to solve for volumetric inflation, source depth, and location.

The uncertainty in model parameters (volume change and source depth) as a function of number of stations is plotted in figure 4. Resolution of source depth, location, and volume change improved as the number of stations increased. For example, the uncertainty in source depth for a network of five stations is $\pm \sim 2.5 \mathrm{~km}$, indicating that, statistically, the source could reside anywhere within $\sim 5 \mathrm{~km}$ of the surface (given an actual source depth of $2 \mathrm{~km}$ ). However, the uncertainty drops to $\pm \sim 1 \mathrm{~km}$ with a network of more than 15 stations. Volumechange uncertainty was similarly affected by the number of stations.

\section{Requirements}

Level 1-None.

Level 2-None.

Level 3 - Locate and estimate volume change within a subsurface deformation source.

Techniques/instrumentation:

- 7 to 10 continuous-mode GPS stations, of which 4 are located within $5 \mathrm{~km}$ of the volcanic center and 1 is outside the area of expected surface deformation (to provide a stable reference)

- Four to six borehole tiltmeters located within 5 to 10 $\mathrm{km}$ of the volcanic center

- Annual InSAR measurements (if practical)

- GPS surveys every 1 to 5 years (depending on conditions) to supplement InSAR measurements and data from continuous-mode GPS stations

Level 4-Provide robust constraints on the location of, and volume change within, a subsurface deformation source.

Techniques/instrumentation:

- 16 to 20 continuous-mode GPS stations, of which at least 8 are located within 5 to $10 \mathrm{~km}$ of the volcanic center and 2 are located outside the area of expected surface deformation (to provide a stable reference)

- 5 to 10 borehole tiltmeters located within $5-10 \mathrm{~km}$ of the volcanic center

- Annual (summer to summer) InSAR measurements (if practical) at volcanoes that are covered by snow during the winter, and as frequently as practical for snow-free volcanoes

- Annual GPS surveys, particularly at those volcanoes where InSAR measurements are impossible and where 
continuous-mode GPS stations have detected anomalous surface deformation

\section{Distinction of Volcanic from Nonvolcanic Surface Deformation}

\section{Capability}

Differentiating volcanic from nonvolcanic surface deformation is crucial to the interpretation of observed displacement patterns. For example, in 1998, anomalous ground displacements were detected in continuous- and survey-mode GPS data from Popocatépetl volcano (Larson and others, 2004). The surface deformation was associated with transient tectonic slip on the subduction interface, more than $100 \mathrm{~km}$ away from the volcano. In November 2000, continuous-mode GPS stations located south of the Kîlauea summit moved toward the ocean by $2 \mathrm{~cm}$ over a period of $\sim 48$ hours (Cervelli and others, 2002b). The large GPS network on the Island of Hawai' $i$ enabled scientists to determine that the surface deformation was a result of aseismic fault slip and not directly linked to the ongoing eruption of the volcano (Cervelli and others, 2002b; Brooks and others, 2006; Segall and others, 2006).

At arc volcanoes, significant nonvolcanic deformation is always possible because of their location in a tectonically active region. Ground displacements at most arc volcanoes result from a combination of at least three processes: (1) motion of the arc relative to the stable plate, (2) elastic strain resulting from the locked main thrust interface of the subduction zone, and (3) volcanic deformation signals. The first process can generally be accounted for by referencing the displacements of the volcano-monitoring stations to a site that is nearby but off the volcano. When no such reference site is available, however, when the reference site has failed, or when the volcanic signal is exceptionally large and displaces the reference site, such a correction will be impossible. The second process can generally be accounted for by using data from periods of no volcanic signal, or from other regional data. Elastic strain from a locked subduction zone is commonly manifested as approximately arcnormal contraction, can be comparable in magnitude to the volcanic signal, and varies widely in space (for example, Zweck and others, 2002). In addition, volcanoes commonly lie on or near active uppercrustal faults, motion on which can cause significant ground displacements that may or may not be related to volcanic sources. Numbers of deformation-monitoring instruments, particularly GPS, should be increased for volcanoes on or near major faults to better distinguish magmatic and tectonic processes.

\section{Instrumentation}

One to several far-field continuous-mode GPS stations are needed to model and remove nonvolcanic deformation signals from local volcano-monitoring networks, with the number depending on the size of each volcanic center and the complexity of its tectonic environment. The high-spatialresolution capability of InSAR can also be exploited to detect fault motion and other nonvolcanic deformation; thus, repeat InSAR analyses should also be performed.

\section{Requirements}

Level 1-None.

Level 2-None.

Level 3 - Confirm whether or not anomalous ground displacements are caused by magmatic phenomena.

Techniques/instrumentation:

- 7 to 10 continuous-mode GPS stations, of which at least 2 are located outside the area of expected deformation (to provide a stable reference) and 4 are located within 5 to $10 \mathrm{~km}$ of the volcanic center

- Annual InSAR measurements (if practical)

- GPS surveys every 1 to 5 years (depending on conditions) to supplement InSAR measurements and data from continuous-mode GPS stations

Level 4 - Confirm whether or not anomalous ground displacements are caused by magmatic phenomena and, if not, identify the cause of the anomalous displacement.

Techniques/instrumentation:

- 16 to 20 continuous-mode GPS stations, of which at least 5 are located within 5 to $10 \mathrm{~km}$ of the volcanic center and 2 are located outside the area of expected deformation (to provide a stable reference)

- Annual (summer to summer) InSAR measurements (if practical) at volcanoes that are covered by snow during the winter, more frequently (approximately monthly) at snow-free volcanoes

- Annual GPS surveys to supplement data from InSAR measurements and continuous-mode GPS stations.

\section{Summary-Recommendations for Level 1-4 Networks}

Level 1: Baseline deformation measurements using InSAR, GPS, and (or) leveling surveys should future activity warrant additional data collection.

Level 2: InSAR measurements, GPS, and (or) leveling surveys repeated every 5 to 10 years (depending on logistics). As the price of GPS equipment continues to fall, it may become cost effective to locate a single continuous-mode GPS station within 5 to $10 \mathrm{~km}$ of the volcanic center instead of 
conducting more frequent surveys (which generally are costly in terms of personnel requirements).

Level 3: 7 to 10 continuous-mode GPS stations, of which 4 are located within 5 to $10 \mathrm{~km}$ of the volcanic center and 1 is located outside the area of expected deformation; and 4 to 6 borehole tiltmeters, all located within 5 to $10 \mathrm{~km}$ of the volcanic center. Annual InSAR measurements, and GPS, microgravity, and (or) leveling surveys (as appropriate) every 1 to 5 years, to supplement data collected from continuously-operating stations.

Level 4: 16 to 20 continuous-mode GPS stations, of which at least 8 are located within 5 to $10 \mathrm{~km}$ of the volcanic center and 2 are located outside the area of expected deformation; 5 to 10 borehole tiltmeters, all located within 5 to $10 \mathrm{~km}$ of the volcanic center; and one continuous gravimeter (if conditions are appropriate). Annual (summer to summer) InSAR measurements at volcanoes that are covered by snow during the winter, monthly at snow-free volcanoes. Annual GPS, microgravity, and (or) leveling surveys (as appropriate and warranted) to supplement data collected from continuously-operating stations.

\section{Gas Monitoring}

\section{Background}

Rising magma degasses under lower pressure conditions that allow volatile components to exsolve from the magma. As more gases exsolve, the increasing pressure forces the gas to escape through fractures and cracks. Rising magma also heats rock masses beneath volcanic centers, causing the water in shallow aquifers and hydrothermal systems to boil and release additional gases and steam from the volcano. The gases that reach the surface during periods of quiescence or volcanic unrest can provide valuable information about ongoing magmatic and hydrologic processes in the subsurface (for example, Sutton and others, 1992).

Carbon dioxide $\left(\mathrm{CO}_{2}\right)$, the most abundant gas in magma after water $\left(\mathrm{H}_{2} \mathrm{O}\right)$, is one of the most important volatile component for forecasting eruptive activity because it can provide the earliest geochemical indication of the onset of restlessness within a volcanic system (for example, Gerlach and others, 1997; McGee and others, 2000; Gerlach and others, in press). Owing to its low solubility in magma, $\mathrm{CO}_{2}$ exsolves from magma early in the ascent process. Thus, an increase in $\mathrm{CO}_{2}$ output and (or) in the ratio of $\mathrm{CO}_{2}$ to other gases are key indicators that magma ascent is in progress. Recent examples of such phenomena include increases in diffuse $\mathrm{CO}_{2}$ degassing observed at the summit of Usu Volcano (Japan) several months before the March 31, 2000, eruption (Hernandez and others, 2001), and increases in $\mathrm{CO}_{2}$ ratios relative to other gases observed before the eruption of Mount Etna (Italy) in 2004-5 (Aiuppa and others, 2006) and Mount St. Helens (Washington) in 2004 (Gerlach and others, 2008).

At any given time, most volcanoes in Alaska and the Western United States are characterized by weak degassing, which typically includes one or more low-temperature fumaroles, commonly at the summit, and a fairly extensive hydrothermal system (for example, McGee and others, 2001). The presence of a hydrothermal system will affect the chemistry of the gases after they exsolve from the magma (Symonds and others, 2001). An important point about $\mathrm{CO}_{2}$, however, is that in addition to exsolving from magma early in the ascent process, it is not easily removed by passage through hydrothermal waters. In contrast, almost all other magmatic gasses, such as sulfur dioxide $\left(\mathrm{SO}_{2}\right)$, hydrogen chloride $(\mathrm{HCl})$, and water vapor, undergo complex chemical reactions as they move from magma through ground water or hydrothermal systems toward the surface (for example, Doukas and Gerlach, 1995; Gerlach and others, 1998; Symonds and others, 2001; Gerlach and others, in press). For example, a significant fraction of $\mathrm{SO}_{2}$ will initially react to form hydrogen sulfide $\left(\mathrm{H}_{2} \mathrm{~S}\right)$, which is then emitted from the volcano. Another significant fraction reacts to form sulfate in hydrothermal fluids, or precipitates as elemental sulfur (Christenson, 2000; Symonds and others, 2001), which can subsequently be revolatilized with increases in temperature. As a result, as a volcano heats up and more ground water is evaporated, the $\mathrm{SO}_{2} / \mathrm{H}_{2} \mathrm{~S}$ ratio increases, and the $\mathrm{CO}_{2} / \mathrm{SO}_{2}$ and $\mathrm{CO}_{2} / \mathrm{H}_{2} \mathrm{~S}$ ratios change in response to both hydrologic and magmatic conditions. Thus, monitoring multiple gas species and the total output of those species is a critical requirement of any volcano-monitoring system during periods of quiescence and unrest.

The three most important tools for gas monitoring include periodic direct measurements of fumarole geochemistry, estimates of the emission rates of major gas species $\left(\mathrm{CO}_{2}, \mathrm{SO}_{2}\right.$, and $\mathrm{H}_{2} \mathrm{~S}$ ) by airborne or ground-based techniques, and measurements of $\mathrm{CO}_{2}$ diffusion through soils. Some of these tools are continuous, providing geochemical data that complement continuous seismic and ground-deformation data streams. Two types of continuous instrumentation are noteworthy, the first of which is a continuous soil- $\mathrm{CO}_{2}$ fluxmeter, which is used to measure a time series of $\mathrm{CO}_{2}$ output from a single site. One of the initial long-term (1998-2000) deployments of a continuous soil- $\mathrm{CO}_{2}$ fluxmeter in the United States was at Mammoth Mountain (California) (Rogie and others, 2001). Since then, many volcanoes worldwide have been instrumented with permanent continuous soil- $\mathrm{CO}_{2}$-flux stations, including Solfatara, Mount Vesuvius, Mount Etna, and Stromboli (Italy) (Granieri and others, 2003; Brusca and others, 2004); Nea Kameni (Greece) (URL http://ismosav.santorini.net/index.php?id=577 (accessed June 18, 2008)); Masaya (Nicaragua) (Hernández and others, 2002); Santa Ana, San Miguel, San Vincente, Berline, and Auachapan volcanoes and hydrothermal areas (El Salvador) (URL http://www.westsystems.it/cm_networks.html (accessed June 18, 2008)); San Miguel, Terceira, and Graciosa Islands (Azores) (Ferreira and others, 2005); and Usu Volcano 
(Notsu and others, 2000). As of this writing (spring 2008), no permanent continuous soil- $\mathrm{CO}_{2}$ fluxmeters have been installed at U.S. volcanoes.

The second noteworthy type of continuous instrumentation is a scanning minispectrometer that can be used to continuously measure $\mathrm{SO}_{2}$-emission rates at degassing volcanoes (for example, Edmonds and others, 2003; Elias and others, 2006). The instrument became commercially available in 2007 and has great promise for use in volcano monitoring. Such devices operate remotely and need only a view of the plume to collect data during daylight hours, and so they can be installed at low-elevation sites. Such spectrometers have also been built into noncommercial but permanent scanning devices that continuously monitor total $\mathrm{SO}_{2}$ output at volcanoes, including Soufrière Hills (Montserrat) (Edmonds and others, 2003), Mount Etna (Aiuppa and others, 2006), and White Island (New Zealand) (Werner and others, 2006b).

Another promising device is the ultraviolet (UV) digital camera developed by Bluth and others (2007) that can detect and image $\mathrm{SO}_{2}$ in a plume, even when the plume is invisible to the naked eye. Such a camera could be used in continuous or survey mode. The main advantage of this camera is that instead of simply detecting the presence of $\mathrm{SO}_{2}$ it allows a quantitative view of plume size. Use of this instrument will allow for better airborne monitoring because the operator will know where to fly to make a thorough measurement, as well as for qualitative assessments of $\mathrm{SO}_{2}$ degassing, particularly for detecting an increase in $\mathrm{SO}_{2}$ emission in the presence of a hydrothermal system. Finally, the camera can be used to measure how large and concentrated a plume is. One drawback to the camera, however, is that it operates in the UV part of the spectrum and so cannot measure $\mathrm{CO}_{2}$. In addition, neither scanning spectrometers nor UV cameras can obtain measurements at night.

Where degassing rates are too low to be detected by the above instruments, the sampling of hot springs, crater lakes, and streams can be used to detect geochemical changes. Using all of the techniques in combination not only promotes a comprehensive understanding of the chemistry of major gas emissions but also provides information on the total output of the volcano, both of which are fundamental in understanding the progression of magmatic processes that aid hazard forecasting.

\section{Gas Monitoring-Required Capabilities}

The key to interpreting or identifying degassing anomalies is obtaining sufficient baseline data. Differences in volcano type, background degassing rates, local hydrology, and geography (for example, high versus low latitude) will result in different baselines for every volcano, making it somewhat difficult to prescribe a particular gas-monitoring strategy for volcanoes of a particular threat level. In general, more gas-monitoring methods should be used at higher threat volcanoes because the stakes are higher. However, volcanoes of any threat level that exhibit one or more degassing phenom- ena should be monitored by methods and techniques needed to establish baseline degassing data, with the sampling frequency of baseline data dictated by the threat level (see table 1). Thus, the following components (described in detail below) are required for an adequate gas-monitoring strategy: during periods of quiescence, (1) establishment of a long-term geochemical baseline by sampling and analysis of fumaroles and hot springs and other field measurements; (2) establishment of a gas-emission-rate baseline; and (3) continuous monitoring of total gas output, fumarole geochemistry, and soil gases at selected volcanoes; and during periods of unrest and (or) eruption, (4) deployment of ground-based instrumentation and (5) repeat airborne measurements of volcanic plumes.

\section{Establishment of a Long-Term Geochemical Baseline by Sampling and Analysis of Fumaroles and Hot Springs and Other Field Measurements}

Occasional sampling and analysis of gases from existing fumaroles on quiescent volcanoes is a basic part of any long-term strategy for gas monitoring, requiring collection of high-quality fumarole samples and performance of a detailed chemical analysis on each sample to characterize the gases emitted from each volcano during noneruptive conditions. However, of the $\sim 60$ medium-threat to very high threat volcanoes with accessible fumaroles (see table 3), few, if any, have routine gas-monitoring schedules emplaced. As a result, many years may pass between fumarole sampling, even at volcanoes where a period of unrest has recently occurred. For example, Mount Baker (Washington) underwent a period of unrest in the 1970s (McGee and others, 2001), yet its fumaroles have been sampled only three times in the past 10 years, when Werner and others (in press) observed that the $\mathrm{CO}_{2} / \mathrm{H}_{2} \mathrm{~S}$ ratio increased by nearly 100 percent, highlighting the need for more routine gas monitoring at Mount Baker and other volcanoes with active fumarole fields.

\section{Establishment of a Gas-Emission-Rate Baseline}

Measuring the amount of gas emitted from a volcano is critical because it reflects the amount of magma degassing at depth. $\mathrm{CO}_{2}$, which is the key gas indicator of magma degassing in the subsurface, is the only measured gas that will not react significantly with ground water before being emitted at the surface. Inactive volcanoes normally emit $\mathrm{CO}_{2}$ in amounts ranging from undetectable to a few hundred metric tons per day. Though not well characterized, quiescent volcanoes in arc settings can emit 1,000 to 2,000 $\mathrm{t}$ of $\mathrm{CO}_{2}$ per day if a convecting or constant magma source is present in the subsurface (Werner and others, 2006a; Werner and others, 2008). Abundances of $\mathrm{CO}_{2}, \mathrm{SO}_{2}$, and $\mathrm{H}_{2} \mathrm{~S}$ in volcanic plumes can be monitored by instruments mounted in a fixed-wing aircraft (Gerlach and others, 1997). Such gas-plume measurements, which were developed by the USGS, have since been 
used by other research groups in Japan (Shinohara and others, 2003) and New Zealand (Werner and others, 2006a; Werner and others, in press). Measurements of gas emissions during periods of quiescence are important so that a baseline can be established to use as a bench mark for identifying later anomalous increases in the output of $\mathrm{CO}_{2}$ and other gases. Of the 102 moderate-threat to very high threat volcanoes identified in NVEWS, $\sim 30$ have emitted measurable gas plumes at some point since the 1970 s. Of these 30 volcanoes, scientists have completed baseline measurements at just more than half (Doukas and Gerlach, 1995; Gerlach and others, 2008).

\section{Continuous Monitoring of Total Gas Output, Fumarole Geochemistry, and Soil Gases at Selected Volcanoes}

It would be logistically difficult to establish continuous gas-monitoring networks at all potentially active volcanoes, particularly those that are remote and (or) that have harsh winter conditions. However, installation of networks and (or) complete periodic long-term (days to months) deployments at those U.S. volcanoes that are either erupting (Kîlauea and Anatahan (Mariana Islands) as of this writing (spring 2008)) or quiescent yet display a significant level of degassing (for example, Mount Baker, Yellowstone (Wyoming), and Chiginagak (Alaska)). The new off-the-shelf UV scanning technologies for $\mathrm{SO}_{2}$ and automated measurement systems for diffuse $\mathrm{CO}_{2}$ should be deployed at such volcanoes for periods of days to months each year when field conditions permit. Water- and gas-sampling deployments should be coordinated so that these datasets can be compared. Current examples of U.S. volcanoes with a component of continuous gas-monitoring capability include Kỉlauea, Mammoth Mountain, Mauna Loa, and Yellowstone (for example, McGee and others, 2000; Sutton and others, 2001). Potential candidates for ground-based networks include Anatahan, Augustine Volcano (Alaska), Mount Cleveland (Alaska), Fourpeaked Mountain (Alaska), Mount Baker, Pagan (Mariana Islands), and Shishaldin (Alaska).

\section{Deployment of Ground-Based Instrumentation}

Once a volcano becomes restless, access to fumaroles near the active crater may not be practical or safe. With increasing gas-emission rates, however, the restless volcano provides a window of opportunity to install a high-quality network of continuous gas-monitoring stations that would provide insight into the nature of the unrest and data to aid in forecasting. Therefore, a required component of NVEWS is the establishment of such networks. These gas-monitoring networks could be likened to the routine seismic- or deformation-monitoring networks that are deployed year round. Although a cache of ground-based geochemistry equipment does not currently exist, it should include rugged deployable chemical sensors (for example, Shinohara, 2005) and scanning optical spectrometers to determine real-time gas-emission rates (for example, Edmonds and others, 2003; Elias and others, 2006), as well as telemetry equipment, be sufficient to instrument 12 sites, or two volcanoes undergoing heightened unrest (allow five stations per volcano to accommodate all wind directions, with one spare station per volcano), and meteorologic stations and various other portable and deployable instruments for field surveys and continuous measurements as appropriate at individual volcanoes of various threat levels.

\section{Repeat Airborne Measurements of Volcanic Plumes}

In conjunction with ground-based gas measurements, frequent airborne measurements of volcanic plumes will be needed to identify key changes in volcano degassing that signal various stages in the progression of a volcano from unrest to eruption. The first important change to identify is the transition from baseline to markedly higher $\mathrm{CO}_{2}$-emission rates $(>1,000 \mathrm{t} / \mathrm{d}$, depending on the volcano), indicating that magma is likely ascending toward the surface. At a volcano with sufficient ground water for removing $\mathrm{SO}_{2}$, such gases as $\mathrm{H}_{2} \mathrm{~S}$ will likely appear early in the plume (for example, Doukas and Gerlach, 1995; McGee and others, 2001; Gerlach and

Table 3. Initial estimates of number of degassing U.S. volcanoes and types of degassing phenomena per threat level.

\begin{tabular}{|c|c|c|c|c|c|}
\hline Threat level & $\begin{array}{c}\text { Total number of } \\
\text { volcanoes / } \\
\text { number of } \\
\text { degassing } \\
\text { volcanoes }\end{array}$ & $\begin{array}{c}\text { Number of } \\
\text { volcanoes with } \\
\text { detectable plumes } \\
\text { using airborne } \\
\text { capabilities }\end{array}$ & $\begin{array}{l}\text { Number of volcanoes } \\
\text { with accessible } \\
\text { fumaroles }\end{array}$ & $\begin{array}{c}\text { Number of volcanoes } \\
\text { with accessible hot } \\
\text { springs }\end{array}$ & $\begin{array}{l}\text { Number of volcanoes } \\
\text { with diffuse degassing }\end{array}$ \\
\hline Very high & $18 / 18$ & 11 & 15 & 15 & 6 \\
\hline High & $37 / 31$ & 10 & 22 & 14 & 3 \\
\hline Very low & 32 & 0 & 0 & 0 & 0 \\
\hline
\end{tabular}


others, in press). The total output of these constituents (that is, $\mathrm{CO}_{2}$ and $\mathrm{H}_{2} \mathrm{~S}$ ) cannot be monitored by the remote-scanning techniques included in the equipment cache; direct measurement from an aircraft is required. The second important change to identify is the transition to very high $\mathrm{CO}_{2}$-emission rates $(>10,000 \mathrm{t} / \mathrm{d})$, which indicates an open system with magma intruding into higher levels beneath the volcano (Gerlach and others, 1994; Gerlach and others, 1997). Other gases, such as $\mathrm{H}_{2} \mathrm{~S}$, may also continue to be emitted, but the $\mathrm{SO}_{2} / \mathrm{H}_{2} \mathrm{~S}$ ratio will increase as temperatures continue to rise and ground water boils off (Gerlach and others, in press). The third important change to identify is the appearance of significantly high levels of $\mathrm{SO}_{2}$ and $\mathrm{HCl}$ in the plume (Giggenbach and Sheppard, 1989; Edmonds and others, 2002; Edmonds and others, in press), which are definitive signals of a shallow magma source because they indicate that the volcanic edifice has heated up sufficiently to establish dry passageways from depth to the surface so that $\mathrm{SO}_{2}$ and other acidic gases exsolving from the magma are no longer being removed or "scrubbed" by ground water or a hydrothermal system (Symonds and others, 2001). Finally, measurements of very high, sustained gas-emission rates $\left(>10,000 \mathrm{t} \mathrm{CO}_{2} / \mathrm{d}\right.$ and $\left.>1,000 \mathrm{t} \mathrm{SO}_{2} / \mathrm{d}\right)$ indicate that magma has intruded to a high level beneath the volcano and that an eruption is likely imminent (McGee and Casadevall, 1994; Delgado-Granados and others, 2001; Sutton and others, 2001).

\section{Summary-Recommendations for Level 1-4 Networks}

Initial estimates of the number and types of gas emissions from U.S. volcanoes by threat level show that nearly 100 percent of very high threat, 80 percent of high-threat, and 60 percent of medium-threat volcanoes display active degassing (table 3). Higher-threat-level volcanoes commonly display multiple types of gas emission, whereas lower-threat-level volcanoes exhibit few, if any, signs of degassing (table 3 ). The NVEWS gas-monitoring strategy is prioritized both by the threat level of the volcano and the type of gas emission that the volcano displays. For example, Mount Rainier (Washington) is a very high threat level volcano with accessible fumaroles and hot springs, but the gas output by fumaroles is not measurable by airborne instruments (see Gerlach and others, in press, table 1), nor are areas of diffuse degassing known. Thus, the gas-monitoring strategy for Mount Rainier would include regular fumarole and hot-spring measurements and a yearly airborne survey (flyby for detection/measurement if detected) to assess whether a $\mathrm{CO}_{2}$ plume is being emitted in the absence of any thermal signature. At a lower-threat-level volcano with the same types of gas emissions, the gas-monitoring strategy would be the same but with a longer lag time between ground-based or airborne sampling. Our recommendations are as follows (table 4):

\section{Requirements}

Level 1-None.

Level 2 - Characterize background gas emissions on a 5 to 10 -year schedule.

Techniques/instrumentation:

- Establish a list of candidate sites appropriate for ground-based (for example, fumarole sampling, diffuse degassing), airborne, or continuous gas monitoring

- Measure fumarole geochemistry every 5 to 10 years to establish baselines

- Conduct airborne plume detection where appropriate

Level 3 - Characterize background gas emissions on a 3 to 5 -year schedule.

Techniques/instrumentation:

- Establish baseline datasets for fumarole geochemistry (3 to 5-year schedule)

- Measure airborne gas-emission rates when appropriate (3 to 5-year schedule)

- Obtain continuous or survey measurements as appropriate

Level 4 - Characterize background gas emissions on a 1 to 2 -year schedule with real-time monitoring as appropriate.

Techniques/instrumentation:

- Establish a list of candidate sites as per level 2

- Establish baseline datasets for fumarole chemistry (1 to 2-year schedule)

- Routinely measure airborne gas-emission rates (annually if quiescent, more frequently if in a state of unrest)

- Obtain continuous or survey measurements at any candidate volcano with an adequate level of degassing

If at any point a volcano becomes active, all applicable techniques will be used to assess emerging volcanic activity. The degree of response will be dictated by the degree of unrest, logistics, and the hazard level. For example, minor unrest might be best monitored by annual sampling, whereas more frequent sampling would be performed in the event of significant unrest. Newly evolving techniques need to be sought and incorporated into the USGS gas-monitoring program as appropriate.

Finally, gas monitoring generally requires more human involvement than seismic, deformation, or other geophysically based monitoring because in only a relatively few situations can gas monitoring be accomplished solely by telemetered 
Table 4. Key elements of gas-monitoring strategy.

\begin{tabular}{|c|c|c|c|c|c|}
\hline Threat level & $\begin{array}{l}\text { Element 1: } \\
\text { Regular fumarole } \\
\text { and hot-spring } \\
\text { sampling or } \\
\text { soil- degassing } \\
\text { measurements }\end{array}$ & $\begin{array}{l}\text { Element 2: } \\
\text { Baseline emis- } \\
\text { sion flights (only } \\
\text { if plumes likely } \\
\text { or fumaroles are } \\
\text { inaccessible) }\end{array}$ & $\begin{array}{c}\text { Element 3: } \\
\text { Continuous deploy- } \\
\text { ments and (or) } \\
\text { measurements } \\
\text { surveys (if viable } \\
\text { plume exists) }\end{array}$ & $\begin{array}{c}\text { Element 4: } \\
\text { Deployment of } \\
\text { continuous arrays } \\
\text { (if in unrest situ- } \\
\text { ation) }\end{array}$ & $\begin{array}{l}\text { Element 5: } \\
\text { Frequent emission } \\
\text { flights during vol- } \\
\text { canic unrest (if in } \\
\text { unrest situation) }\end{array}$ \\
\hline Very high & $\mathrm{X}$ & $\mathrm{X}$ & $(\mathrm{X})$ & $(\mathrm{X})$ & $(\mathrm{X})$ \\
\hline High & $\mathrm{X}$ & $(\mathrm{X})$ & $(\mathrm{X})$ & $(\mathrm{X})$ & (X) \\
\hline Medium & $\mathrm{X}$ & --- & --- & $(\mathrm{X})$ & $(\mathrm{X})$ \\
\hline Low & --- & --- & --- & $(\mathrm{X})$ & $(\mathrm{X})$ \\
\hline Very low & --- & --- & --- & $(\mathrm{X})$ & $(\mathrm{X})$ \\
\hline
\end{tabular}

instrumentation. Thus, adequate funding for staffing and fieldwork is as critical as funding for equipment. The success of any gas-monitoring program depends on having trained professionals to sample, analyze, document, and interpret measurements.

We do not recommend that continuous gas-monitoring networks be established on volcanoes without significant degassing and (or) with low threat levels. However, baseline gas geochemistry and emission rates must be established for level 2-4 volcanoes to provide background data essential for interpreting the magmatic and hydrologic processes accompanying unrest. Additional instrumentation should be deployed for continuous long-term monitoring on an individual basis at volcanoes with sufficient degassing. A critical component of any gas-monitoring strategy is the acquisition and maintenance of a standalone cache of equipment that can be quickly deployed at a volcano once unrest is detected, including telemetered instruments for gas monitoring, portable instruments for various surveys, and precision spectrometers for airborne detection of gases in volcanic plumes, along with the technical support needed to establish and maintain the cache. Specific recommendations for all gas-monitoring equipment are included in the section below entitled "Mobile-Response Instrumentation."

\section{Hydrologic Monitoring}

\section{Introduction}

Hydrologic monitoring at volcanoes has two basic functions: detecting changes in the chemistry, temperature, discharge, or water levels of lakes, rivers, springs, and wells near volcanoes that can be caused by volumetric strains or increases in gas flux associated with moving magma; and detecting sediment-rich floods, or lahars, that result from water combining with loose rocks and sediment along the slopes of a volcano. These two capabilities require different strategies and instrumentation. Detection of changes in water chemistry and other properties requires systematic measurements in either continuous or survey mode. Far-traveled lahars, however, generally become an issue only after a volcano has begun to show signs of unrest or to erupt. Thus, lahar monitoring is mostly performed after volcanic unrest has been detected. In this section, we discuss the role that each of these functions should play in eruption forecasting and monitoring at U.S. volcanoes.

\section{Hydrologic Monitoring—Required Capabilities}

\section{Detection of Changes in Water Level, Chemistry, and Temperature ("Water Monitoring")}

Capability

Changes in the chemistry, temperature, level, and clarity of water in wells are, in general, poorly studied phenomena at volcanoes (Sparks, 2003). The potential for water changes to provide warning of impending eruptions was demonstrated at Mount Vesuvius (Italy) in 1631 A.D., where several water wells in towns 5 to $7 \mathrm{~km}$ from the summit were reported to be dirty, increasingly salty, or dry several weeks before a major eruption (Rolandi and others, 1993; Rosi and others, 1993; Bertagnini and others, 2006). Several post-1631 eruptions of Vesuvius were similarly preceded by changes in well-water levels (Bertagnini and others, 2006). Other examples of precursory water changes include decreases in the polythionate content of crater-lake water 2 months before the 1982 eruption 
of Yugama (Japan) crater lake (Takano and Watanuki, 1990); significant decreases in flow rate from springs $\sim 8 \mathrm{~km}$ from the summit of Mayon (Philippines) before most eruptions in the 20th century (Sandoval and others, 2000); increases in crater-lake water temperatures 3 months before the 1990 eruption of Kelut Volcano (Indonesia) (Lesage and Surono, 1995); systematic water-level changes in two wells within $1 \mathrm{~km}$ of the vent several months prior to the 2000 eruption of Usu Volcano (Japan) (Shibata and Akita, 2001); and increases in $\mathrm{CO}_{2}, \mathrm{H}_{2}$, and He contents in shallow wells before the 2002-3 eruption of Stromboli Volcano (Italy) (Carapezza and others, 2004). Several other examples were mentioned by Newhall and others (2001).

Despite these and other examples, the relation between geochemical and thermal anomalies in water and volcanic unrest is probably specific to each type of volcano, if not individual volcanic centers, and will likely be difficult to assess without volcano-specific hydrologic models. Research at Mammoth Mountain (California) (Evans and others, 2002), Three Sisters (Oregon) (Evans and others, 2004), and Mount St. Helens (Washington) (Bergfeld and others, 2008) has shown that not all springs and streams on a volcano respond to unrest. Furthermore, determining whether hydrologic anomalies are related to volcanic unrest, to residual effects of previous intrusions or eruptions, or to nonvolcanic phenomena, such as increases or decreases in meteoric-water flux, disruptions due to earthquakes, and manmade pollution, is difficult at best. Additionally, the case studies cited in the previous paragraph all were based on data collected from sites relatively close to the volcano, a factor that makes such monitoring logistically complex and (or) dangerous at many volcanoes. Also, it is difficult to determine in advance the placement of monitoring sites, for two reasons: (1) hydrothermal systems in volcanic settings are complex, and the ability to detect hydrologic changes at a given site depends on how directly linked the site is to the hydrothermal system, something that cannot be known without a good understanding of it; and (2) at large systems like Yellowstone (Wyoming), continuous monitoring of the vast number of geothermal features is impractical (Lowenstern and others, 2006; Hurwitz and others, 2007). For these and other reasons, "water monitoring" strategies are still evolving, and a generic standard is difficult to define.

\section{Instrumentation}

Most water monitoring at U.S. volcanoes has been accomplished by sampling surveys (for example, Evans and others, 2004; Bergfeld and others, in press) and by stream gauges that are a part of the USGS' National Water Information System (URL http://waterdata.usgs.gov/usa/nwis/ (accessed June 18, 2008)). Such monitoring should be continued and, possibly, enhanced along all major drainages that stem from a volcanic system so as to assemble long-term baseline geochemical and discharge trends. In addition, continuous real-time monitoring of temperature, geochemistry, and (or) water levels should be implemented at all high-threat and very high-threat volcanoes with crater lakes, springs, wells, and (or) streams that are known or believed likely to have direct linkages to, or be influenced by processes in, the volcanic conduit, with the number and type of instruments tailored to site-specific considerations. Real-time water-monitoring networks are currently deployed at Yellowstone National Park (Lowenstern and others, 2006) and Long Valley caldera (California) (URL http://lvo.wr.usgs.gov/HydroStudies.html (accessed June 18, 2008)). Candidates for such networks include Lassen Peak, Clear Lake, and Medicine Lake (California); Crater Lake and Newberry Volcano (Oregon); Mount St. Helens and Mount Rainier (Washington); Mount Spurr, Kaguyak, Mount Katmai, and Aniakchak (Alaska); and Anatahan (Mariana Islands).

Site conditions commonly pose severe technical challenges for continuous probes, including high-temperature waters, corrosive waters, and energetic and (or) sedimentladen streams. Under these conditions, instrumentation is best kept in the laboratory, and water samples should be collected in the field and brought into the laboratory for analysis. Sampling programs should include measurement of total discharge so that the mass-flow rate of magma-derived constituents can be calculated. Where conditions allow for installation of continuous probes, periodic sampling and gauging of the site should also be performed to calibrate the probe and establish rating curves for water and dissolved species of interest.

Until the reliability and maintenance requirements of continuous probes are improved, installation and maintenance of continuous, telemetered sites on all high-threat-level volcanoes is not yet practical. We instead recommend that the NVEWS budget include funds to install continuous telemetered probes at two or three sites on several of the highest threat level volcanoes that also are reasonably easy to access, so as to assess the reliability of such probes and their capability of detecting chemical, thermal, or other changes. As reliability improves, more volcanoes should be instrumented. In addition, newly evolving specific ion probes, such as for dissolved inorganic carbon, chloride, sulfate, boron, arsenic, and mercury, should be sought. Periodic sampling surveys should be performed at all other volcanoes, with less frequent surveys at lower threat level volcanoes. Instrumentation for such surveys should be maintained in an equipment cache. We note that probe technology is rapidly changing, with models generally becoming obsolete in $\sim 2$ years. Thus, we do not recommend a large equipment cache for crisis response; one or two continuous probes should be sufficient for response.

\section{Requirements}

Level 1-Compile an inventory of all surficial manifestations (springs, lakes, streams) of a hydrothermal system; survey all important springs, lakes, and streams every 10 to 20 years to establish baseline rating curves and temperature/ water-level profiles. 
Level 2-Complete surveys every 5 to 10 years.

Level 3 - Compile a list of candidate sites where continuous monitoring might be fruitful; complete surveys every 3 to 5 years.

Level 4-Where feasible, establish continuous monitoring of water levels, chemistry, and temperature (initially at two or three easily accessible volcanoes until probe reliability is improved); complete surveys every 1 to 2 years.

\section{Lahar Monitoring}

\section{Capability}

Lahars are among the most persistent, farthest reaching, and destructive of all volcanic hazards. Primary lahars can occur during unrest or eruptions and may be triggered by syneruptive rapid melting of snow and ice, lake breakouts, or heavy rains in conjunction with large eruptive columns. Secondary lahars follow eruptions, when clastic deposits are mobilized by heavy rainfalls or lake breakouts; they can occur sporadically for years to decades after large eruptions. Some lahars can travel many tens to hundreds of kilometers in river drainages stemming from volcanoes, as during the 1980 eruption of Mount St. Helens (for example, Janda and others, 1981) and the 1991 eruption of Mount Pinatubo (Philippines) (Major and others, 1996; Pierson and others, 1996).

\section{Instrumentation}

Unlike seismic, deformation, and gas monitoring, lahar monitoring has no predictive value leading up to an eruption. Instead, volcanic unrest and eruption typically precede initiation of lahars that pose significant hazards to people and property. Therefore, networks of lahar-detection stations are best deployed at volcanoes with significant ground-based hazards after unrest has been detected with other monitoring techniques. In rare instances, however, there may be little time between unrest detection and lahar occurrence. For example, in early 2007, large lahars stemming from a relatively small eruption of Nevado del Huila (Colombia) were preceded by only hours of precursory seismicity (A. Lockhart, written communication, 2007). Thus, for such volcanoes as Mount Rainier with significant population and (or) infrastructure exposure to lahar hazards, installation of lahar-detection stations may be appropriate before any period of unrest. Regardless, a significant amount of preparatory work, such as characterizing lahar hazards for individual drainages, site identification, and establishing radio telemetry networks, is required to ensure that rapid deployment can be accomplished, and is recommended at all volcanoes before any unrest begins.

Passage of lahars has been sensed with tripwires, seismometers, and, most effectively, with geophones that have a response in the lower end of the acoustic spectrum (20-200 $\mathrm{Hz}$ ). One system developed expressly for lahar detection is the USGS' acoustic flow monitor (AFM) (Donavan and Meyer, 1994; Hadley and LaHusen, 1995). AFMs have been deployed at Mount Redoubt (Alaska) (Dorava and Meyer, 1994), Mount St. Helens (Hadley and LaHusen, 1995), Mount Rainier (Lockhart and Murray, 2003), and several non-U.S. volcanoes (Marcial and others, 1996; Lavigne and others, 2000). In such deployments, AFMs are placed near stream channels but far enough removed from the channels so that they are not exposed to damaging flows and thus remain functional for the multiple flows that typically occur during and after eruptions. AFMs require relatively little power and are rapidly deployable. At least of three AFMs are required to adequately monitor a single drainage. Given that most volcanoes have four or five major drainages, at least of 15 AFMs are required to adequately monitor an individual volcano. Because AFMs would principally be deployed in crisis-response mode, the equipment (including power and telemetry) should reside in an equipment cache (see section below entitled "MobileResponse Instrumentation"). We recommend that the AFM cache be large enough to allow for response at two volcanoes.

Another critical element in lahar monitoring is precrisis assessment of lahar hazards and risks for individual drainages. The LAHARZ program (Schilling, 1998) or other GIS-based software is ideal for this purpose; however, the accuracy of such assessments partly depends on the accuracy of digital elevation models (DEMs). Therefore, acquisition of DEMs through aerial photography or lidar surveys is also critical, particularly at high-threat-level volcanoes with nearby population centers and (or) infrastructure.

\section{Requirements}

Level 1-Qualitatively assess (through geologic mapping or other means) lahar hazards at individual volcanic centers, using existing topographic data.

Level 2-Same as for level 1.

Level 3 - Same as for Level 1. At those volcanoes judged to have a significant lahar potential, also quantitatively assess lahar hazards by such computer programs as LAHARZ, acquire accurate DEMs for improved GIS-based assessments of lahar hazards, and locate suitable sensor sites and telemetry paths.

Techniques/instrumentation:

- Aerial photography or lidar surveys for production of accurate DEMs at volcanoes of interest, to be used with the LAHARZ program or equivalent software to quantitatively assess lahar hazards

Level 4-Same as for level 3, plus secure permits for future sensor and telemetry sites; establish links with local civil authorities; deploy AFMs at volcanoes judged to have 
extreme population/infrastructure exposure where rapid response might be impossible.

Techniques/instrumentation:

- 30 AFMs in an equipment cache for instrumenting two volcanoes (five drainages per volcano, three AFMs per drainage).

\section{Remote Sensing}

\section{Introduction}

In this section, we review current capabilities and techniques for volcano monitoring by using remote-sensing techniques and outline the NVEWS requirements for appropriate levels of monitoring. We define "remote sensing" in the context of this report to encompass any methods used for volcano monitoring that involve data acquired from satellitebased, airborne, and certain ground-based instruments. Several commonly used remote-sensing techniques, including InSAR and airborne gas measurements, are described in more detail elsewhere in this report and so are omitted here.

In contrast to ground-based monitoring, remote sensing (in particular, satellite) can cover large regions (thousands of kilometers wide). Thus, routine use of satellite resources needs to be considered on a regional observatory level rather than on an individual volcano basis. However, some satellite data sources (for example, high-resolution commercial data) and airborne or ground-based techniques are more appropriately considered on an individual-volcano basis, and so our recommendations include both regional and local requirements for effective volcano monitoring by remote sensing.

\section{Satellite Remote Sensing}

A wide range of volcanic phenomena can be monitored and measured by using satellite remote sensing, including volcanic ash and gas clouds generated by explosive eruptions; thermal emissions from lava domes, lava flows, and pyroclastic flows; topographic changes and large-scale surface deformation of volcanic edifices in association with eruptions; extent of eruptive deposits; and passive (noneruptive) $\mathrm{SO}_{2}$ emissions. Within the USGS' Volcano Hazards Program, AVO has made the greatest use of satellite data to monitor and characterize volcanic activity (Schneider and others, 2000). Satellite data sources vary widely with respect to spectral coverage (UV, visible, mid-IR, thermal IR, and microwave), spatial resolution (submeter to tens of kilometers), and temporal resolution (15 minutes to several weeks). Satellite data, which have been used by AVO since 1988, include three general types:

1. Image data acquired through receiving stations run by the Geographical Network of Alaska at the University of Alaska, Fairbanks, and by the Naval Research Laboratory in Monterey, Calif. These data were originally designed for meteorologic or atmospheric applicationsfor example, advanced very high resolution radiometer (AVHRR), moderate-resolution imaging spectroradiometer (MODIS), and geostationary operational environmental satellite (GOES) - and are characterized by low spatial resolution $(0.25 \mathrm{~km}$ m to $8 \mathrm{~km})$ but relatively high temporal resolution (15-60 minutes for GOES and four times per day for AVHRR and MODIS). The data are available for analysis within 15 to 60 minutes from the start of image acquisition and are routinely used by AVO for near-real-time assessment of volcanic activity.

2. Image data received and processed by a data archive center or a commercial entity. These data-for example, Landsat, advanced spaceborne thermal emission and reflection radiometer (ASTER), Ikonos, Quickbird, Radarsat, and Envisat - are typically used for terrestrial remote-sensing applications and are characterized by high spatial resolution ( $>1$ to $60 \mathrm{~m}$ ) but low temporal resolution (weeks to months). Commonly, a specific tasking and purchase request is required for data collection. The data are generally available for analysis within a day or two of collection, depending on the speed of initial processing by the ground receiving station.

3. Image graphics or derived data available through online sources. These data-for example, GOES images produced by the National Oceanic and Atmospheric Administration (NOAA)'s Satellite Services Divisions (URL http://www.ssd.noaa.gov/VAAC/ (accessed June 18, 2008)) and MODIS true-color composites produced by the National Aeronautics and Space Administration (NASA)'s Goddard Space Flight Center (URL http:// rapidfire.sci.gsfc.nasa.gov/(accessed June 18, 2008)) —are typically in a GIF or JPEG format and show predefined products that cannot be queried to obtain actual values, such as brightness temperature or reflectance, thus limiting their usefulness. An example of derived data is the University of Hawai i's MODVOLC project (URL http:// modis.higp.hawaii.edu/ (accessed June 18, 2008)), which automatically scans MODIS data and maps the global distribution of thermal hotspots from all sources, including volcanoes and fires, in near-real time and posts the results on the World Wide Web (Wright and others, 2004).

These three general types of satellite data have enabled $\mathrm{AVO}$ to monitor volcanoes on various temporal and spatial scales. The capabilities they enable are applicable to any volcano in a particular geographic area that is covered by a given satellite. Given that the satellites and associated data are not owned and operated by the USGS, major issues with satellite imagery include the cost and effort required to maintain sufficient Internet connectivity and the need to have interoperational agreements in place to ensure timely access to all types of satellite imagery. 


\section{Airborne and Ground-Based Measurements}

The other component of volcano monitoring by remote sensing is the use of imagery and data acquired by airborne and ground-based instrumentation, including, but not limited to, aerial photography, lidar, forward-looking infrared (FLIR), radiometers, radar, and timelapse photography with telemetered digital cameras installed at remote sites. Each of these techniques and (or) instrument types is spatially limited to individual volcanoes, and so we include recommendations for the capabilities required for level 1-4 networks and the instrumentation required to enable a given capability.

\section{Remote Sensing—Required Capabilities}

\section{Detection, Tracking, and Measurement of Volcanic Clouds}

\section{Capability}

Explosive volcanic eruptions inject large amounts of volcanic ash, gases, and acidic aerosols into the atmosphere as volcanic clouds that pose a serious hazard to aviation. Rapid detection and tracking of these clouds are vital to mitigation of this hazard. Volcanic Ash Advisory Centers and Meteorological Watch Offices have the primary responsibility for issuing warnings of volcanic clouds to aviation. AVO's experience, however, has demonstrated that remote-sensing personnel in a volcano observatory play a critical role in rapid identification and verification of volcanic clouds, partly because of their ready access to other relevant data, and that shared situational awareness between meteorological groups and volcano observatories can provide an improved understanding of the hazard. The required capabilities are detection (or confirmation) of an explosive eruption; detection and tracking the constituents (ash and $\mathrm{SO}_{2}$ ), height, and movement of a volcanic cloud; and measurement of the eruption size and vertical ash-mass distribution.

The aviation industry has requested notification of an eruption within 5 minutes of its onset (Hufford and others, 2000). For this reason, rapid determination of whether volcanic ash is being produced and, if so, to what altitude is critical. The 1999 eruption of Shishaldin Volcano (Alaska) was monitored almost entirely by using seismic and satellite remote-sensing methods (for example, Nye and others, 2002). In this eruption, the satellite data aided the interpretation of seismic data by differentiating between a subplinian eruption (to $>13 \mathrm{~km}$ above sea level) and intense lava fountaining with associated low-level ash clouds. In addition, remote sensing has detected eruptions of volcanoes with no seismic-monitoring network, such as the largely effusive eruption of Okmok Volcano (Alaska) in 1999 (Patrick and others, 2003) and the explosive eruption of Mount Cleveland (Alaska) in 2001 (Dean and others, 2004).

The most commonly used ash-detection technique utilizes thermal -IR data collected at two wavelengths (also known as split window; Prata, 1989; Watson and others, 2004). This method has its limitations, however, particularly for small eruption clouds and (or) those mixed with meteorologic clouds, where ash detection is more difficult. The precise ashdetection limit is difficult to define because it involves several factors, some of which are related to the volcanic cloud and others to atmospheric conditions at the time of the eruption. As a result, satellite detection of eruptions is most effective when using full resolution image data rather than image graphics (such as JPEG or PNG formats). $\mathrm{SO}_{2}$ emission from explosive eruptions is also detectable by using thermal-IR (Watson and others, 2004) and UV data (Krueger, 1995). $\mathrm{SO}_{2}$ can be a good indicator of an explosive eruption because few nonvolcanic sources of the gas would be confused with an eruption. Creation of automated alarm systems based on satellite data may be possible; however, temporal resolution is limited to several images per day over most volcanoes.

Another means for detecting ash is through ground-based radar systems, which have been deployed at several volcanic systems to rapidly detect and measure ash eruptions (Rose and others, 1995; Lacasse and others, 2004). The National Weather Service's next- generation radar (NEXRAD) network provides adequate coverage of many volcanoes within the United States, although it has some limitations. For example, its ability to accurately determine volcanic-cloud heights depends on the distance from the radar station to the erupting volcano and the scanning strategy used. In the 2006 eruption of Augustine Volcano, these factors contributed to uncertainties of $3 \mathrm{~km}$ in cloud-height estimates. Information on volcanic-cloud height is vital for hazard mitigation once an eruption occurs, because it is needed to initialize models of ash-cloud movement and fallout. Satellite-derived cloud heights are commonly used in eruption response but offer no information about vertical mass distribution, which is an important parameter in these models, especially under conditions of significant wind shear. Ground-based radar offers the potential to estimate this parameter, especially if vertical cross sections through the eruption column can be rapidly and repeatedly produced. This capability does not exist within the current NEXRAD system. Another limitation of NEXRAD is that some scanning strategies require as long as 10 minutes to complete a single pass, too long a time frame for providing timely ash warnings to any aircraft in the vicinity. Finally, observatories do not have direct real-time access to NEXRAD data. Therefore, the availability of dedicated ground-based weather radar stations under the control of volcano observatories would greatly increase the timely detection and measurement of volcanic clouds.

\section{Requirements}

Level 1-Detect eruptions that produce volcanic clouds up to flight levels through routine daily checking of satellite 
imagery. At this level, capability to detect an eruption is limited, possibly taking many hours.

Techniques/instrumentation:

- Periodic (at least daily) analysis of graphical image products, including thermal-IR, split-window, and aerosol-index images for detecting volcanic ash and volcanically derived $\mathrm{SO}_{2}$ graphics.

Level 2-Same as for level 1.

Level 3-Detect explosive eruptions within 30 minutes of onset, estimate cloud height, and track volcanic clouds.

Techniques/instrumentation:

- Rapid acquisition and processing of full-resolution calibrated AVHRR, MODIS, and GOES data with automated ash and $\mathrm{SO}_{2}$ alarms, with near-real-time $\mathrm{SO}_{2}$ detection by satellite-based sensors (for more details, see section below entitled "Measurement of $\mathrm{SO}_{2}$ Emissions" below)

Level 4-Same as for level 3, except detect ash to flight levels within 5 minutes regardless of eruption size; and rapidly measure cloud/column parameters, such as height, eruption rate, and vertical mass distribution.

Techniques/instrumentation:

- Same as for level 3, plus deployment of ground-based Doppler radar within $100 \mathrm{~km}$ of the volcanic center (where possible)

\section{Characterization of Thermal Emissions}

\section{Capability}

As magma intrudes a volcano, surface heat flow may increase, resulting in increases in fumarolic activity or formation of new fumaroles, fractures, hot springs, crater lakes, and (or) melting of snow and ice. Detection and tracking of heat flow can play an important role in understanding the processes involved in volcanic unrest. Once an eruption begins, the particular type of volcanic activity needs to be characterized because the potential heat sources may vary, such as lava lakes, lava domes, lava flows, and pyroclastic flows. Thermal data can be acquired at various spatial and temporal resolutions: low spatial (but high temporal) resolution from AVHRR, GOES, and MODIS for hot objects (Harris and others, 1997; Dehn and others, 2002; Wright and others, 2002; Wright and others, 2004); medium resolution from ASTER and Landsat (Flynn and others, 2001; Ramsey and Dehn, 2004); very high spatial resolution from airborne or ground-based thermalimaging radiometers (Harris and others, 2005a; Vaughan and others, 2005); very high temporal resolution from point-source radiometers (Harris and others, 2005b); and all-weather capability from passive microwave radiometers (Wadge and others, 2005).

Satellite detection of thermal emissions depends on several factors, including the temperature of a hot feature and its immediate area, the temperature of the adjacent ground, the dynamic range of the sensor (that is, the temperature at which it is saturated), and the spatial resolution of the sensor. Lowresolution satellite images may detect hotspots, but origin of a given thermal anomaly may be difficult to determine. For example, warm features that cover a large percentage of a satellite pixel can have a pixel temperature similar to that of a hot feature that covers a very small fraction of a pixel. In general, higher spatial resolution satellite data can provide additional insight into a thermal anomaly by providing a context to its morphology.

Characterization of thermal flux is an important parameter that can be used to evaluate the level of volcanic activity. Thermal flux can be estimated from low-spatial-resolution data but requires knowledge of the subpixel fraction of the hot feature, information obtainable from higher resolution satellite data or thermal-imaging radiometric data. The thermal flux can be further refined into estimates of effusion rate (Harris and others, 1997) and total eruption volume, information applicable to understanding magma supply and aiding lava-flow-hazard assessments. Although effusion rate can be calculated by using low-spatial-resolution satellite data, more accurate estimates are obtainable by using data from thermalimaging radiometers, which have a much higher dynamic range and spatial resolution (Harris and others, 2005a). These higher resolution data (collected from ground or air) can be combined with the synoptic, repetitive view that satellite data provide to produce a time series of lava effusion over the course of an eruption.

\section{Requirements}

Level 1-Detect anomalous thermal activity.

Techniques/instrumentation:

- Temporal comparisons of low-spatial-resolution satellite data, such as AVHRR and MODIS

Level 2-Same as for level 1.

Level 3-Acquire baseline knowledge of the distribution and temperature of thermal features; track changes in thermal features over time; distinguish lava effusion from other thermal signals, such as pyroclastic flows and strombolian activity; characterize thermal flux from lava domes/flows.

Techniques/instrumentation:

- Temporal comparisons of moderate-resolution data, such as Landsat and ASTER

Level 4-Frequently characterize thermal flux; estimate erup- 
tion rates and track changes in thermal features over time.

Techniques/instrumentation:

- High-spatial-resolution georeferenced mapping of lava-dome/flow extent, using airborne or ground-based thermal radiometers

\section{Measurement of $\mathrm{SO}_{2}$ Emissions}

\section{Capability}

Routine airborne and ground-based measurements of volcanic gas emissions are discussed in more detail in the section above entitled "Gas Monitoring," and so this discussion is limited to satellite-based detection of $\mathrm{SO}_{2}$ emissions. As magma intrudes a volcano and moves from depth to the upper levels of the edifice, the reduction in pressure causes dissolved gas to be released. The most commonly released magmatic gases include $\mathrm{H}_{2} \mathrm{O} \mathrm{CO}_{2}$, and $\mathrm{SO}_{2}$, of which only $\mathrm{SO}_{2}$ can be detected and measured by current satellite-based remote-sensing techniques. High rates of $\mathrm{SO}_{2}$ emission indicate that magma has moved to relatively shallow levels in the volcano and that the system has heated up enough to establish dry pathways from depth to the surface. Thus, monitoring gas-emission rates can provide important information on volcanic unrest. Although airborne and (or) ground-based measurement of gas emissions are more sensitive and accurate than satellite-based methods, these measurements are sometimes logistically difficult (if not impossible) at remote volcanoes (such as in the Aleutian or the Mariana Islands). At these volcanoes, routine satellite analysis may be able to provide early notice of volcanic unrest or the onset of an otherwise-undetected low-level eruption.

Satellite detection and measurement of $\mathrm{SO}_{2}$ emissions is possible by using data collected at UV and thermal-IR wavelengths. This method is advantageous because the techniques used at different wavelengths have their individual strengths and weaknesses and the spatial and temporal resolutions of the satellite data also vary. The primary sensors used are the ozone monitoring instrument (OMI) at UV wavelengths, and the atmosphere infrared sounder (AIRS), MODIS, and ASTER in the thermal IR. Of these data, OMI, AIRS, and MODIS are automatically collected, whereas ASTER requires specific tasking. Routine, global, near-real-time processing and distribution of OMI and $\mathrm{AIRS} \mathrm{SO}_{2}$ detection and measurement products to USGS volcano observatories and NOAA agencies has recently begun through a collaborative NASA-funded research project at the University of Maryland, Baltimore. Satellite tasking and analysis of higher resolution ASTER data would occur if OMI or AIRS detected significant changes in $\mathrm{SO}_{2}$ emissions or if other monitoring parameters (that is, earthquakes, deformation, gas flux, thermal flux) indicated unrest. This functionality (known as the ASTER Emergency Scheduling Interface and Control System) currently is avail- able through an ASTER science-team project funded by NASA.

\section{Requirements}

Level 1-Automatically detect increases in $\mathrm{SO}_{2}$ emissions on a daily basis, weather permitting.

Techniques/instrumentation:

- Routine reception of OMI and AIRS data products and an automated alarm for large changes

- Rapid tasking, reception, and processing of ASTER satellite data for volcanoes with elevated unrest

Level 2 - Same as for level 1.

Level 3-Same as for level 1.

Level 4-Same as for level 1.

\section{Preeruption Hazard Assessments}

\section{Capability}

Volcano observatories are responsible for assessing the full range of potential hazards at specific volcanic centers in support of public land-use planning, implementation of emergency-response plans, and general public awareness of volcanic hazards. This effort involves studying a volcano to determine the style and frequency of past eruptions and the potential impacts of future activity. Hazard assessments include descriptions of the history of a given volcano, explanations of likely eruption scenarios, and determination of probable impact zones for the range of expected hazards. These studies require the use of aerial or satellite images, topographic maps, and DEMs to identify past eruptive products and accurately map their distribution.

The most commonly used image sources for geologic and hazard mapping include stereo aerial photographs and highresolution satellite images, such as from Ikonos or Quickbird. These high-spatial-resolution (submeter) data are collected at visible and near-IR wavelengths and can be supplemented by lower resolution (tens of meters) Landsat or ASTER data when additional spectral information would be useful (for example, in identifying the extent of hydrothermal alteration). Satellite data, such as from Ikonos and Quickbird, have licensing restrictions that control their distribution, and so data collected by these and other commercial sources need to be licensed for use amongst the various volcano observatories and their research partners. The management of these data will also require the development of a geospatial database that allows easy search and retrieval of relevant data by observatory scientists. 


\section{Requirements}

Level 1-Acquire baseline image coverage showing a synoptic overview of major landforms and deposits.

Techniques/instrumentation:

- Moderate-resolution data from Landsat and (or) ASTER

Level 2-Same as for level 1.

Level 3-Acquire baseline images suitable for detailed geologic and (or) hazard mapping (if conducted).

Techniques/instrumentation:

- High-spatial-resolution satellite images (from Ikonos or Quickbird) or stereo aerial photographs. Images should be georeferenced and orthorectified

Level 4-Same as for level 3, plus acquire digital elevation data required to model lahar, pyroclastic-flow, or lava-flow hazards.

Techniques/instrumentation:

- High-resolution DEMs from photogrammetry, lidar, or similar methods.

\section{Eruption Documentation and Mapping}

\section{Capability}

During an eruption, there is a constant need to observe and document activity and to map deposits. Various techniques have been developed and utilized since the 1990s that are cost effective and provide increased viewing potential, as well as increased safety for scientific field crews. These techniques include telemetered timelapse and Web cameras, used at Mount St. Helens (Washington), Augustine Volcano (Alaska), and many other volcanoes; low-light cameras to detect incandescence; analysis of repeat photography and (or) high-resolution satellite data; and production of DEMs by photogrammetry and (or) lidar surveys. Owing to the many variables regarding access, logistics, eruption style, and climate, the use of these techniques needs to be tailored to the individual volcano.

Many times, during eruptive activity, visual observations and thermal-IR imaging are limited by steam, clouds, and fog, complicating interpretation of other monitoring data and limiting estimation of eruption rate. A new ground-based instrument known as the All-weather Volcano Topography Imaging Sensor (AVTIS; URL http://www.st-andrews.ac.uk/ mmwave/ mmwave/avtis.shtml (accessed June 18, 2008)) has been developed (Wadge and others, 2005) that combines an active radar surveying instrument (to measure topographic changes) with a passive microwave radiometer (to measure temperature). The instrument has been tested at several volcanoes and has demonstrated the ability to work under various weather conditions at a range of as far as $7 \mathrm{~km}$. If detailed topographic information is not required, the deployment of passive microwave radiometers provides a method to view activity through steam and clouds, provided the area being observed is hot.

Remote cameras are another proven means of documenting eruptions. In the 1980s at Mount St. Helens, the Cascades Volcano Observatory (CVO) deployed film cameras to observe eruptions of lava domes. After operating for several days, the cameras were retrieved, and the film was developed (Topinka, 1992). In 1997, HVO began making use of telemetered video cameras that observed the Pu 'u ' $\bar{O}^{\prime}$ o eruptive vent and transmitted images to the observatory every few seconds (Thornber, 1997). More recently, cameras with near-real-time telemetry have been used to document and monitor eruptions at Soufrière Hills (Montserrat) (Herd and others, 2005), Mount St. Helens (Major and others, in press; Poland and others, in press), and Augustine Volcano (Murray and others, 2006); however, their use depends on adequate lighting and visibility, both of which can be limited during winter eruptions, particularly at high-latitude volcanoes in Alaska. The 2006 eruption of Augustine Volcano provided an opportunity to develop and test low-light (near-IR) video cameras. During the 2006 eruption, a low-light camera originally designed for astronomical observations was established in Homer, about $105 \mathrm{~km}$ east of the volcano. The camera recorded nighttime near-IR signals produced by pyroclastic flows, rockfalls, and steam emissions, all of which corresponded to seismic activity recorded by onisland instruments (Sentman and others, 2006). Although these cameras were powered by standard AC power, they could be configured for field applications.

The best means for measuring eruption rates and largescale topographic changes at an erupting volcano is the construction of DEMs from aerial photography or lidar. For example, DEMs of Mount St. Helens determined primarily from aerial photographs during 2004-06 were used to calculate the extrusive volume over time, providing important constraints on the evolution of the eruption (Schilling and others, in press). DEMs also provide a base for mapping efforts and interpreting volcano structure and morphology and are important for estimating the potential location and extent of lahars and other flow-based volcanic phenomena through such GISbased software as the LAHARZ program (Schilling, 1998).

\section{Requirements}

Level 1 - Generate DEMs from aerial photographs or lidar surveys for mapping purposes and to establish a baseline for hazard assessment, should the volcanic system become active.

Level 2-Same as for level 1.

Level 3 -Perform near-real-time and (or) repeat non-real-time observations under clear-weather conditions. This capability requires repeat acquisition of high-spatial-resolution (georeferenced and orthorectified) satellite images (from 
Ikonos or Quickbird) or aerial photographs; deployment of at least one telemetered Web or time-lapse camera, imaging thermal-IR camera, and (or) low-light camera; and DEMs generated from aerial photographs and (or) lidar surveys.

Level 4-Perform near-real-time and (or) repeat non-real-time observations under all weather conditions. This capability requires repeat acquisition of high-spatial-resolution (georeferenced and orthorectified) satellite images (Ikonos or Quickbird), as well as aerial photographs and (or) lidar surveys for generating DEMs, which should be acquired frequently during periods of unrest and (or) eruptions; and installation of at least two camera systems (Web cameras or remote telemetered digital systems) with different views of the volcano (during periods of unrest, cameras with low-light capabilities should be deployed to document lava extrusion, pyroclastic flows, and so on). During eruptions, ground-based radar and radiometer systems (for example, AVTIS) should be deployed for improved monitoring during poor weather.

\section{Staffing Requirements and Operational- Satellite Data Access}

Currently, analysis of remote-sensing data is integrated into day-to-day operations at AVO, which serves as a center for research in remote sensing within the USGS' Volcano Hazards Program. If NVEWS were ever funded, creation of a remote-sensing center as part of a continuous operations center could be beneficial. Although such a center might be located at AVO, all volcano observatories must have staff with remote-sensing experience. In this way, techniques and data sources can be tailored to meet the varied needs of individual observatories, ensuring that some staff members at each observatory are familiar with remote-sensing data and analysis techniques, an important capability during eruption responses.

Unlike the other monitoring techniques listed in this report, satellite remote sensing utilizes data sources that are not directly under the control of Volcano Hazard Program facilities. Furthermore, although the volcanological community has been involved in specifying requirements, no satellite-based sensors are dedicated to the study of volcanic phenomena. Decisions about such parameters as spatial and temporal resolution, spectral resolution, and wavelength are made to satisfy a broad range of Federal agency requirements and scientific needs. Also, considerable uncertainty exists about current and future satellite missions (costs, engineering and construction leadtime, satellite launch, lifetime in orbit), complicating the planning for robust data access. We recommend that plans for data access acknowledge this issue and account for future changes.

NOAA is responsible for providing operational-satellite data to the United States and its protectorates, primarily in support of the requirements of the National Weather
Service. These data are generated by sensors installed on geostationary (for example, GOES) and polar-orbiting (for example, AVHRR) satellite platforms. In addition, data from the MODIS sensors aboard two NASA satellites are available through direct reception. These two sensors, which have been the primary data sources for volcanic-ash detection and tracking, as well as measurement of thermal anomalies, form the backbone of the AVO remote-sensing program. Direct reception of these data is relatively straightforward and several commercial systems are currently on the market. We note that a new generation of geostationary and polar-orbiting satellites is currently being designed that will likely require different receiving equipment, owing to their increasing data rate.

Ideally, volcano observatories should have direct-reception capabilities so as to reduce data latency and allow access to the full range of data (as opposed to graphical images). The reception of geostationary data for all U.S. volcanoes in theory requires one receiving site for volcanoes within the United States and another within the Commonwealth of the Northern Mariana Islands (CNMI). However, the reception of polar-orbiting data would require at least four receiving sites (Alaska, Hawai i, the Continental United States, and the CNMI) with two antennas at each site to receive both AVHRR and MODIS data streams. Several other options for data access are possible, including partnerships with university groups (such as the current AVO access through the University of Alaska, Fairbanks) and (or) through an interagency agreement with NOAA's National Environmental Satellite, Data, and Information Service (NESDIS). Regardless of the sources of satellite data, significant bandwidth will be required to move data effectively between receiving sites and volcano observatories.

\section{Summary-Recommendations for Level 1-4 Networks}

Level 1-Daily scans of various routinely collected satellite imagery to detect eruption-related ash clouds and gas plumes, as well as anomalous thermal activity, at individual volcanic centers; baseline imagery for hazard assessments and mapping.

Level 2-Same as for level 1.

Level 3 - Same as for level 1, except detection of explosive eruptions within 30 minutes of onset; estimation of cloud height and tracking of ash clouds; distinction of thermal signals from lava effusion, Strombolian activity, and pyroclastic flows; characterization of thermal flux from lava domes, flows, and other features; acquisition of digital elevation data for modeling lahar, pyroclastic-flow, and (or) lavaflow hazards, as well as for detailed geologic mapping; and deployment of one telemetered camera.

Level 4 -Same as for level 3, except detection of ascent of volcanic clouds to flight levels within 5 minutes of onset; 
rapid measurements of cloud height, eruption rate, and vertical mass distribution (requires deployment of groundbased Doppler radar system within $100 \mathrm{~km}$ of volcanic center); and near-real-time measurements under all weather conditions (requires installation of ground-based telemetered camera systems and (or) ground-based radar/radiometer systems, as well as acquisition of Ikonos/Quickbird or equivalent satellite imagery).

\section{Boreholes and Borehole Instrumentation}

Installation of instrument packages in deep (several hundred to several thousand meters) boreholes near volcanoes is a relatively recent development in volcano monitoring. Examples of instrumented boreholes in volcanic areas include the Long Valley Exploratory Well (LVEW) in California, drilled in conjunction with the International Continental Drilling Program to 2.3-km depth in 1991 and to 3-km depth in 1998 (for example, Sorey and others, 2000; Prejean and Ellsworth, 2001; Fischer and others, 2003; Roeloffs and others, 2003); and the CALIPSO project at Montserrat, which includes a series of four 200-m-deep holes (for example, Mattioli and others, 2004; Voight and others, 2006). As of this writing (spring 2008), boreholes are being drilled near several U.S. volcanoes by the Plate Boundary Observatory through the National Science Foundation's Earthscope project (URL http:// pboweb.unavco.org/ (accessed June 18, 2008)). Such boreholes contain various instrumental packages to record seismicity and downhole stress, strain, temperature profile, water level, and (or) fluid pressure. In the next subsection, we briefly review some of the capabilities enabled by borehole installations at volcanoes.

\section{Capabilities Enabled by Boreholes}

\section{High-Quality Recordings}

A principle benefit of borehole seismometers and strainmeters is operation in an environment insulated from noise created at the surface by wind, rain, rivers, animals, and machinery. Such noise sources commonly degrade the quality of data obtained from surface-based instruments. For example, seismometers at high-altitude and (or) high-latitude sites on the flanks of volcanoes are particularly susceptible to being temporarily overwhelmed by the wind and flood noise associated with strong storm systems. Borehole seismometers, however, have demonstrably higher signal-to-noise ratios of seismic and strain recordings than surface-based instruments (for example, Prejean and Ellsworth, 2001). Thus, from a prac- tical perspective, the consistently high signal-to-noise ratio of borehole seismometers provides a reliable record of seismicity regardless of surface noise levels.

Changes in surface temperature are another source of noise, particularly for tiltmeters and strainmeters. Temperature changes cause expansion or contractions at the surface, diminishing with depth. Borehole tiltmeters and strainmeters are less vulnerable to temperature changes than those buried at 4- to 6-m depth (M. Lisowski and E. Roeloffs, oral communs., 2006) and so are more sensitive to volcano-related deformation.

An indirect source of noise on seismic records is the uppermost several tens to hundreds of meters of the crust, which generally is highly fractured and thus highly attenuative. Prejean and Ellsworth (2001) compared earthquakes recorded by surface seismometers and LVEW borehole seismometers and reported that borehole records had much more impulsive $P$ - and $S$-wave arrivals and much higher frequency content and were much less affected by scattering and attenuation than recordings on surface seismometers. Because a primary goal of volcano seismology is to determine the nature of a seismic source, recordings that are as minimally contaminated by scattering and attenuation as possible are highly desirable. Thus, borehole seismometers would likely increase a network's ability to detect changes in seismic sources (see section above entitled "Seismic Monitoring" for more discussion of seismic sources), as well as to determine the processes that generate various types of seismicity.

\section{Direct Measurements of Subsurface Geology and Hydrology}

Another primary attribute of boreholes is that they provide a window into subsurface geologic, hydrologic, and thermal regimes that are otherwise constrained only by surface measurements. For geologic structure, borehole cores are the only means for directly and systematically sampling the conduit structure in volcanic areas, which is best accomplished by boreholes drilled on or within volcanic systems, rather than on their flanks. Two examples of such boreholes include the LVEW borehole (for example, McConnell and others, 1995) and a $\sim 1.3-\mathrm{km}$-deep hole drilled into a volcanic conduit at Unzen Volcano (Japan) (Nakada and Eichelberger, 2004; Nakada and others, 2004; Uto and others, 2004). The LVEW borehole core provided a continuous stratigraphic section to 2.3-km-depth below Long Valley caldera's resurgent dome. Samples from this core led to the discovery of numerous rhyolitic dykes and sills that intruded the Bishop Tuff (McConnell and others, 1995), providing direct evidence for postcaldera intrusions in the area of the resurgent dome. The Unzen drilling project provided unprecedented samples from the conduit of a recently active volcano. Preliminary results indicate that the conduit was composed of a series of relatively thin dikes and that the dikes intruded around, rather than through, the 
preexisting conduit (Nakada and others, 2004), a perspective that proved important for constructing magmatic-system models during renewed eruptive activity at Mount St. Helens (Washington) in 2004 (for example, Pallister and others, in press).

Borehole instruments have yielded important insights into the hydrothermal systems associated with volcanic areas (Farrar and others, 2003; Fischer and others, 2003; Pribnow and others, 2003; Roeloffs and others, 2003). For example, Farrar and others (2003) examined flow tests and fluid samples from the LVEW borehole and several other shallower drill holes in the Long Valley area to delineate likely flowpaths and properties of the hydrologic system underneath the resurgent dome. Such information is critical for interpreting the volcanic unrest at Long Valley caldera and elsewhere. They also obtained mineralogic evidence in LVEW core samples from fracture zones for previous periods of more vigorous and energetic fluid circulation than is presently occurring. Roeloffs and others (2003) used borehole-pressure-transducer recordings from the LVEW and four other boreholes in Long Valley caldera to investigate earthquake-induced ground water-level changes that have persisted for days to weeks. They inferred that such changes are caused by accelerated inflation of Long Valley caldera's resurgent dome, inflation too small to be detected by surface-based deformation monitoring.

Finally, thermocouples and thermisters installed in boreholes enable thermal profiling of the crust. Thermal information is valuable because it places constraints both on the position of the brittle-ductile transition, which is an important control on whether or not earthquakes can occur, and on the potential positions of magma bodies. For example, temperatures at 3-km-depth in the LVEW borehole were found to be a low $100^{\circ} \mathrm{C}$, a surprising result, given the previous assumption that a $>800^{\circ} \mathrm{C}$ magma chamber resided at 6- to $8-\mathrm{km}$ (Fischer and others, 2003; Pribnow and others, 2003).

\section{Recommendations}

Because boreholes are a relatively new component of volcano-monitoring networks and have considerable associated costs and logistic difficulties (for example, Mattioli and others, 2004), the "bang for the buck" of borehole instruments in routine volcano monitoring has yet to be established. Given that many U.S. volcanoes lie in remote areas with little or no road access, we believe that it is impractical to make a blanket recommendation for their installation at volcanoes, even those ranking as very high threat, where logistic difficulties are prohibitive. Nonetheless, borehole instrumentation has clearly resulted in significant improvements in both quality of recordings and knowledge of subsurface systems, improvements that translate into improved monitoring and early-warning capabilities. For these reasons, we recommend that where logistics and cost are not prohibitive, at least one instrumented borehole be drilled at very high threat volcanoes, as well as those that exhibit persistent signs of unrest, and that funding for several boreholes be included in NVEWS budget projections.

\section{Mobile-Response Instrumentation}

Particularly during the early years of NVEWS, most U.S. volcanoes will probably remain undermonitored. In addition, volcanoes judged to have a low to moderate threat level (Ewert and others, 2005) could awaken and, as a result, would need to have instrumentation installed rapidly. For these reasons, an equipment cache needs to be readily available for rapid response in the event of unrest at a U.S. volcano. Given that volcanoes in Alaska and Hawai' $i$ are frequently active, it is possible that several U.S. volcanoes will experience unrest simultaneously, as happened in 2004, 2005, and 2006, when unrest or eruptions occurred at Anatahan (Mariana Islands), Augustine Volcano (Alaska), Chiginagak (Alaska), Mount Cleveland (Alaska), Mauna Loa (Hawai`i), Mount Spurr (Alaska), Mount St. Helens (Washington), Pagan (Mariana Islands), Three Sisters (Oregon), and Veniaminoff (Alaska), as well as continuous eruptive activity at Kīlauea (Hawai' $i)$. Therefore, we recommend that sufficient numbers of seismometers, acoustic sensors, GPS receivers, tiltmeters, gravimeters, remote cameras, AFMs, gas-monitoring instruments, and airborne and ground-based remote-sensing devices be made available and placed in a state of readiness for bringing two level 2 networks up to level 4 in the event of volcanic unrest.

On the basis of maximum instrument numbers for a level 4 network, the proposed equipment cache should include equipment for at least 20 seismometers (including 12 broadband sensors), 2 strong-motion sensors, 4 acoustic sensors, 30 dual-frequency GPS stations, 10 tiltmeters (mostly for installation in shallow boreholes, although some platform tiltmeters would allow for flexibility in crisis deployments), 1 or 2 gravimeters, and $30 \mathrm{AFMs}$. The cache should also include a full suite of instruments for tracking surface-based phenomena once an eruption has started, primarily gas-monitoring and remote-sensing equipment for both airborne and ground-based monitoring. For ground-based gas monitoring, sufficient equipment (including telemetry) should be available in the cache to enable installation of five scanning UV spectrometers, two $\mathrm{SO}_{2}-\mathrm{CO}_{2}$-monitoring stations, one automated soil- $\mathrm{CO}_{2}$-flux-monitoring station, one weather station, and one repeater site, as well as equipment for performing periodic field surveys, including two portable $\mathrm{SO}_{2} \mathrm{UV}$ spectrometer systems, one portable $\mathrm{H}_{2} \mathrm{~S}$-measurement system, one portable soil- $\mathrm{CO}_{2}$-flux-measurement system, and one portable multigas analyzer. For airborne gas monitoring, required equipment includes one IR spectrometer for $\mathrm{CO}_{2}$ measurements, one UV spectrometer for $\mathrm{SO}_{2}$ measurements, two electrochemical sensors for $\mathrm{H}_{2} \mathrm{~S}$ and $\mathrm{SO}_{2}$ measurements, one GPS receiver with National Marine Electronics Association (NMEA) output and 
aircraft antenna, one master datalogger for all airborne instruments, one multichannel recorder for inflight display, and one laptop computer for measurement and instrument control. For remote sensing, the cache should include at least one groundbased and one airborne thermal radiometer (such as AVTIS), two airborne-based FLIR instruments, four telemetered cameras, two low-light cameras, and two ground-based Doppler radar systems. A lightning-detection system should also be included for tracking volcanic clouds.

In addition to sensors, the equipment cache will need to include equipment to provide power and telemetry for ground-based instrument, including batteries, solar panels, radios, cabling, housing, and mounting equipment, as well as radio repeaters to ensure continuous data streams for stations that are installed in remote areas. Some of this equipment (especially GPS units and gravimeters) may be used to support deformation-monitoring surveys during times when the cache is not needed, but should be readily available for crisis responses (that is, not used in "semipermanent" deployments that will require several days to recover). The cache would be kept fresh by rotating instruments out for permanent deployments as part of routine maintenance and network construction, and replacing these instruments with newer models, thereby facilitating network repairs and keeping the cache up to date.

A remaining issue is where to house the equipment cache. We note that each volcano observatory will need to maintain sufficient spare equipment to effect repairs on ground-based networks. The cache might be viewed as a collective equipment reserve at all observatories, or it could be managed separately from the supply reserves that each observatory must maintain.

\section{Acknowledgments}

We thank the following people for their valuable input into and (or) reviews of sections of this report: Maurizio Battaglia (University of Rome), Deb Bergfeld (USGS), Bernard Chouet (USGS), Dan Dzurisin (USGS), Marie Edmonds (Cambridge University), Bill Evans (USGS), Cynthia Gardner (USGS), Terry Gerlach (USGS), Michael Hamburger (University of Indiana), Rosalind Helz (USGS), Dave Hill (USGS), Shaul Hurwitz (USGS), Andy Lockhart (USGS), Jake Lowenstern (USGS), Steve Malone (University of Washington), Tom Murray (USGS), Chris Newhall (USGS emeritus), Andrew Newman (Georgia Tech), Paul Okubo (USGS), David Oppenheimer (USGS), Sue Owen (Jet Propulsion Laboratory), Evelyn Roeloffs (USGS), Paul Segall (Stanford University), Roger Smith (University of Utah), Kurt Spicer (USGS), Erik Sturkell (Nordic Volcanological Center, Iceland), Motoo Ukawa (National Research Institute for Earth Science and Disaster Prevention, Japan), and John Vidale (University of Washington). John Ewert, Cynthia Gardner, George Havach, and Jake Lowenstern reviewed the entire manuscript, and their thoughtful and thorough comments and attention to detail greatly improved its readability, organization, and relevance.

\section{References Cited}

Aiuppa, A., Federico, C., Giudice, G., Gurrieri, S., Liuzzo, M., Shinohara, H., Favara, R., and Valenza, M., 2006, Rates of carbon dioxide plume degassing from Mount Etna volcano: Journal of Geophysical Research, v. 111, no. B9, 8 p., doi:10.1029/2006JB004307.

Aloisi, M., Bonaccorso, A., Gambino, S., Mattia, M., and Puglisi, G., 2003, Etna 2002 eruption imaged from continuous tilt and GPS data: Geophysical Research Letters, v. 30, no. 23, 5p., doi:2210.1029/2003GL018896.

Amelung, F., Yun, S.-H., Walter, T.R., Segall, P., and Kim, S.-W., 2007, Stress control of deep rift intrusion at Mauna Loa volcano, Hawaii: Science, v. 316, no. 5827, p. 1026-1030.

Arciniega-Ceballos, A., Chouet, B.A., and Dawson, P.B., 1999, Very long-period signals associated with vulcanian exploration at Popocatepetl Volcano, Mexico: Geophysical Research Letters, v. 26 no. 19, p. 3013-3017.

Aster, R., Mah, S., Kyle, P., McIntosh, W., Dunbar, N., Johnson, J., Ruiz, M., and McNamara, S., 2003, Very long period oscillations of Mount Erebus Volcano: Journal of Geophysical Research, v. 108, no. B11, p. ESE6.1ESE6.22, doi:10.1029/2002JB002101.

Auger, E., D’Auria, L., Martini, M., Chouet, B., and Dawson, P., 2006, Real-time monitoring and massive inversion of source parameters of very long period seismic signals; an application to Stromboli Volcano, Italy: Geophysical Research Letters, v. 33, no. 4, 5 p., doi:10.1029/2005GL024703.

Battaglia, J., Ferrazzini, V., Staudacher, T., Aki, K., and Cheminee, J.-L., 2005, Pre-eruptive migration of earthquakes at the Piton de la Fournaise volcano (Reunion Island): Geophysical Journal International, v. 161, p. 549-558.

Battaglia, M., Roberts, C., and Segall, P., 1999, Magma intrusion beneath Long Valley Caldera confirmed by temporal changes in gravity: Science, v. 285, no. 5436, p. 2119-2122.

Battaglia, M., Segall, P., and Roberts, C., 2003, The mechanics of unrest at Long Valley caldera, California. 2. Constraining the nature of the source using geodetic and micro-gravity data: Journal of Volcanology and Geothermal Research, v. 127, no. 3-4, p. 219-245. 
Battaglia, M., Troise, C., Obrizzo, F., Pingue, F., and De Natale, G., 2006, Evidence for fluid migration as the source of deformation at Campi Flegrei caldera (Italy): Geophysical Research Letters, v. 33, no. 1, 4p., doi:10.1029/2005GL024904.

Bergfeld, D., Evans, W.C., McGee, K.A., and Spicer, K.R., in press, Pre- and post-eruptive investigations of gas and water samples from Mount St. Helens, Washington, 2002 to 2005, chap. 25 of Sherrod, D.R., Scott, W.E., and Stauffer, P.H., eds., A volcano rekindled; the renewed eruption of Mount St. Helens, 2004-2006: U.S. Geological Survey Professional Paper 1750.

Berrino, G., Corrado, G., and Riccardi, U., 2006, On the capability of recording gravity stations to detect signals coming from volcanic activity; the case of Vesuvius: Journal of Volcanology and Geothermal Research, v. 150, no. 1-3, p. 270-282.

Bertagnini, A., Cioni, R., Guidoboni, E., Rosi, M., Neri, A., and Boschi, E., 2006, Eruption early warning at Vesuvius; the A.D. 1631 lesson: Geophysical Research Letters, v. 33, no. 18, 5 p., doi:10.1029/2006GL027297.

Blong, R.J., 1984, Volcanic hazards; a sourcebook on the effects of eruptions: Orlando, Fla., Academic Press, 424 p.

Bluth, G.J.S., Shannon, J.M., Watson, I.M., Prata, A.J., and Realmuto, V.J., 2007, Development of an ultra-violet digital camera for volcanic $\mathrm{SO}_{2}$ imaging: Journal of Volcanology and Geothermal Research, v. 161, no. 1-2, p. 47-56.

Branca, S., Carbone, D., and Greco, F., 2003, Intrusive mechanism of the 2002 NE-Rift eruption at Mt. Etna (Italy) inferred through continuous microgravity data and volcanological evidences: Geophysical Research Letters, v. 30, no. 20, 4p., doi:2010.1029/2003GL018250.

Brandsdóttir, B., Menke, W., Einarsson, P., White, R.S., and Staples, R.K., 1997, Faroes-Iceland Ridge Experiment - II. Crustal structure of the Krafla central volcano: Journal of Geophysical Research, v. 102, no. B4, p. 7867-7886.

Brooks, B.A., Foster, J.H., Bevis, M., Frazer, L.N., Wolfe, C.J., and Behn, M., 2006, Periodic slow earthquakes on the flank of Kīlauea volcano, Hawai 'i: Earth and Planetary Science Letters, v. 246, no. 3-4, p. 207-216.

Brusca, L., Inguaggiato, S., Longo, M., Madonia, P., and Maugeri, R., 2004, The 2002-2003 eruption of Stromboli (Italy); evaluation of the volcanic activity by means of continuous monitoring of soil temperature, $\mathrm{CO}_{2}$ flux, and meteorological parameters: Geochemistry, Geophysics, Geosystems, v. 5, no. 12, 14 p., doi:10.1029/2004GC000732.

Caplan-Auerbach, J., and McNutt, S.R., 2003, New insights into the 1999 eruption of Shishaldin volcano, Alaska, based on acoustic data: Bulletin of Volcanology, v. 65, p. 405-417.
Carapezza, M.L., Inguggiato, S., Brusca, L., and Longo, M., 2004 , Geochemical precursors of the activity of an openconduit volcano; the Stromboli 2002-2003 eruptive events: Geophysical Research Letters, v. 31, no. L07620, 4p., doi:10.1029/2004GL019614.

Cervelli, P.F., Fournier, T., Freymueller, J., and Power, J.A., 2006, Ground deformation associated with the precursory unrest and early phases of the January 2006 eruption of Augustine Volcano, Alaska: Geophysical Research Letters, v. 33, no. 18, 5p., doi:18310.11029/12006GL027219.

Cervelli, P., Segall, P., Amelung, F., Garbeil, H., Meertens, C., Owen, S., Miklius, A., and Lisowski, M., 2002a, The 12 September 1999 Upper East Rift Zone dike intrusion at Kilauea Volcano, Hawaii: Journal of Geophysical Research, v. 107, no. B7, 13 p., doi:10.1029/2001JB000602.

Cervelli, P., Segall, P., Johnson, K., Lisowski, M., and Miklius, A., 2002b, Sudden aseismic fault slip on the south flank of Kilauea volcano: Nature, v. 415, no. 6875, p. 1014-1018.

Chadwick, W.W., Jr., Archuleta, R.J., and Swanson, D.A., 1988, The mechanics of ground deformation precursory to dome-building extrusions at Mount St. Helens, 1981-1982: Journal of Geophysical Research, v. 93, no. B5, p. 4351-4366.

Chadwick, W.W., Jr., and Swanson, D.A., 1989, Thrust faults and related structures in the crater floor of Mount St. Helens Volcano, Washington: Geological Society of America Bulletin, v. 101, no. 12, p. 1507-1519.

Chouet, B., Dawson, P., and Arciniega-Ceballos, A., 2005, Source mechanism of Vulcanian degassing at Popocatepetl Volcano, Mexico, determined from waveform inversions of very long period signals: Journal of Geophysical Research, v. 110, no. B7, 20 p., doi:10.1029/2004JB003524.

Chouet, B., Dawson, P., Ohminato, T., Martini, M., Saccorotti, G., Giudicepietro, F., De Luca, G., Milana, G., and Scarpa, R., 2003, Source mechanisms of explosions at Stromboli Volcano, Italy, determined from moment-tensor inversions of very-long-period data: Journal of Geophysical Research, v. 108, no. B9, 25 p., doi:10.1029/2002JB001919.

Christenson, B.W., 2000, Geochemistry of fluids associated with the 1995-1996 eruption of Mt. Ruapehu, New Zealand; signatures and processes in the magmatic-hydrothermal system: Journal of Volcanology and Geothermal Research, v. 97 , no. $1-4$, p. $1-30$.

Dean, K.G., Dehn, J., Papp, K.R., Smith, S., Izbekov, P., Peterson, R., Kearney, C., and Steffke, A., 2004, Integrated satellite observations of the 2001 eruption of Mt. Cleveland, Alaska: Journal of Volcanology and Geothermal Research, v. 135 , no. $1-2$, p. 51-73. 
Dehn, J., Dean, K.G., Engle, K., and Izbekov, P., 2002, Thermal precursors in satellite images of the 1999 eruption of Shishaldin Volcano: Bulletin of Volcanology, v. 64, no. 8, p. 525-534.

Delaney, P.T., and McTigue, D.F., 1994, Volume of magma accumulation or withdrawal estimated from surface uplift or subsidence, with application to the 1960 collapse of Kilauea Volcano: Bulletin of Volcanology, v. 56, no. 6-7, p. 417-424.

De Lauro, E., De Martino, S., Falanga, M., Palo, M., and Scarpa, R., 2005, Evidence of VLP volcanic tremor in the band [0.2-0.5] Hz at Stromboli Volcano, Italy: Geophysical Research Letters, v. 32, no. 17, 4 p, doi:10.1029/2005GL023466.

Delgado-Granados, H., Gonzalez, L.C., and Sanchez, N.P., 2001, Sulfur dioxide emissions from Popocatepetl volcano (Mexico): case study of a high-emission rate, passively degassing erupting volcano: Journal of Volcanology and Geothermal Research, v. 108, no. 1-4, p. 107-120.

de Zeeuw-van Dalfsen, E., Rymer, H., Sigmundsson, F., and Sturkell, E., 2004, Net gravity decrease at Askja volcano, Iceland; constraints on processes responsible for continuous caldera deflation, 1988-2003: Journal of Volcanology and Geothermal Research, v. 139, no. 3-4, p. 227-239.

Dieterich, J.H., and Decker, R.W., 1975, Finite element modeling of surface deformation associated with volcanism: Journal of Geophysical Research, v. 80, no. 29, p. 4094-4102.

Dorava, J.M., and Meyer, D.F., 1994, Hydrologic hazards in the lower Drift River basin associated with the 1989-1990 eruptions of Redoubt Volcano, Alaska: Journal of Volcanology and Geothermal Research, v. 62, no. 1-4, p. 387-407.

Doukas, M.P., and Gerlach, T.M., 1995, Sulfur dioxide scrubbing during the 1992 eruptions of Crater Peak, Mount Spurr volcano, Alaska, in Keith, T.E.C., ed., The 1992 eruptions of Crater Peak vent, Mount Spurr volcano, Alaska: U.S. Geological Survey Bulletin 2139, p. 47-57.

Dzurisin, D., 1992, Electronic tiltmeters for volcano monitoring; lessons from Mount St. Helens, in Ewert, J., and Swanson, D., eds., Monitoring volcanoes; techniques and strategies used by the staff of the Cascades Volcano Observatory, 1980-90: U.S. Geological Survey Bulletin 1966, p. 69-83.

Dzurisin, D., 2000, Volcano geodesy; challenges and opportunities for the 21st century: Royal Society of London Philosophical Transactions, ser. A, v. 358, no. 1770, p. 1547-1566.

Dzurisin, D., 2003, A comprehensive approach to monitoring volcano deformation as a window on the eruption cycle: Reviews of Geophysics, v. 41, no. 1, doi:1010.1029/2001RG000107.
Dzurisin, D., 2007, Volcano deformation; geodetic monitoring techniques: Berlin, Springer-Verlag, $441 \mathrm{p}$.

Dzurisin, D., Donnelly-Nolan, J.M., Evans, J.R., and Walter, S.R., 1991, Crustal subsidence, seismicity, and structure near Medicine Lake Volcano, California: Journal of Geophysical Research, v. 96, no. 10, p. 16319-16333.

Dzurisin, D., Poland, M.P., and Bürgmann, R., 2002, Steady subsidence of Medicine Lake Volcano, Northern California, revealed by repeated leveling surveys: Journal of Geophysical Research, v. 107, no. B12, doi:2310.1029/2001JB000893.

Dzurisin, D., Westphal, J.A., and Johnson, D.J., 1983, Eruption prediction aided by electronic tiltmeter data at Mount St. Helens: Science, v. 221, no. 4618, p. 1381-1383.

Dzurisin, D., Wicks, C., Jr. and Thatcher, W., 1999, Renewed uplift at the Yellowstone Caldera measured by leveling surveys and satellite radar interferometry: Bulletin of Volcanology, v. 61, no. 6, p. 349-355.

Edmonds, M., Herd, R.A., Galle, B., and Oppenheimer, C.M., 2003, Automated, high time-resolution measurements of $\mathrm{SO}_{2}$ flux at Soufriere Hills Volcano, Montserrat: Bulletin of Volcanology, v. 65 , no. 8, p. 578-586.

Edmonds, M., McGee, K.A., and Doukas, M.P., in press, Chlorine degassing during the lava dome-building eruption of Mount St. Helens, 2004-2005, chap. 27 of Sherrod, D.R., Scott, W.E., and Stauffer, P.H., eds., A volcano rekindled; the renewed eruption of Mount St. Helens, 2004-2006: U.S. Geological Survey Professional Paper 1750.

Edmonds, M., Pyle, D., and Oppenheimer, C., 2002, HCl emissions at Soufriere Hills Volcano, Montserrat, West Indies, during a second phase of dome building: November 1999 to October 2000: Bulletin of Volcanology, v. 64, no. 1, p. 21-30.

Elias, T., Sutton, A.J., Oppenheimer, C., Horton, K.A., Garbeil, H., Tsanev, V., McGonigle, A.J.S., and Williams-Jones, G., 2006, Comparison of COSPEC and two miniature ultraviolet spectrometer systems for $\mathrm{SO}_{2}$ measurements using scattered sunlight: Bulletin of Volcanology, v. 68, p. 313-322.

Endo, E.T., Malone, S.D., Noson, L.L., and Weaver, C.S., 1981, Locations, magnitudes, and statistics of the March 20-May 18 earthquake sequence, in Lipman, P.W., and Mullineaux, D.R., eds., The 1980 eruptions of Mount St. Helens: U.S. Geological Survey Professional Paper 1250, p. 93-107.

Endo, E.T., and Murray, T., 1991, Real-time seismic amplitude measurement (RSAM); a volcano monitoring tool: Bulletin of Volcanology, v. 53, p. 533-545. 
Evans, W.C., Sorey, M.L., Cook, A.C., Kennedy, B.M., Shuster, D.L., Colvard, E.M., White, L.D., and Huebner, M.A., 2002, Tracing and quantifying magmatic carbon discharge in cold groundwaters; lessons learned from Mammoth Mountain, USA: Journal of Volcanology and Geothermal Research, v. 114, no. 3-4, p. 291-312.

Evans, W.C., van Soest, M.C., Mariner, R.H., Hurwitz, S., Ingebritsen, S.E., Wicks, C.W., Jr., and Schmidt, M.E., 2004, Magmatic intrusion west of Three Sisters, central Oregon, USA; the perspective from spring geochemistry: Geology, v. 32, no. 1, p. 69-72.

Ewert, J.W., Guffanti, M., and Murray, T.L., 2005, An assessment of volcanic threat and monitoring capabilities in the United States; framework for a National Volcano Early Warning System: U.S. Geological Survey Open-File Report 2005-1164, 62 p.

Farrar, C.D., Sorey, M.L., Roeloffs, E., Galloway, D.L., Howle, J.F., and Jacobson, R., 2003, Inferences on the hydrothermal system beneath the resurgent dome in Long Valley Caldera, east-central California, USA, from recent pumping tests and geochemical sampling: Journal of Volcanology and Geothermal Research, v. 127, no. 3-4, p. 305-328.

Fehler, M., 1985, Locations and spectral properties of earthquakes accompanying an eruption of Mount St. Helens: Journal of Geophysical Research, v. 90, no. B14, p. 12729-12740.

Ferreira, T., Gaspar, J.L., Viveiros, F., Marcos, M., Faria, C., and Sousa, F., 2005, Monitoring of fumarole discharge and $\mathrm{CO}_{2}$ soil degassing in the Azores; contribution to volcanic surveillance and public health risk assessment: Annals of Geophysics, v. 48, no. 4-5, p. 787-796.

Fischer, M., Roller, K., Kuster, M., Stockhert, B., and McConnell, V.S., 2003, Open fissure mineralization at $2600 \mathrm{~m}$ depth in Long Valley Exploratory Well (California) - insight into the history of the hydrothermal system: Journal of Volcanology and Geothermal Research, v. 127, no. 3-4, p. 347-363.

Flynn, L.P., Harris, A.J.L., and Wright, R., 2001, Improved identification of volcanic features using Landsat 7 ETM+: Remote Sensing of Environment, v. 78, no. 1-2, p. 180-193.

Garcés, M.A., Hagerty, M.T., and Schwartz, S.Y., 1998, Magma acoustics and time-varying melt properties at Arenal Volcano, Costa Rica: Geophysical Research Letters, v. 25, no. 13, p. 2293-2296.

Garcés, M.A., Harris, A., Hetzer, C., Johnson, J., Rowland, S., Marchetti, E., and Okubo, P.G., 2003, Infrasonic tremor observed at Kīlauea Volcano, Hawai'i: Geophysi- cal Research Letters, v. 30, no. 20, p. SDE 2-1 to 2-4, doi:10.1029/2003GL018038.

Garcés, M.A., Iguchi, M., Ishihara, K., Morrisey, M., Sudo, Y., and Tsutsui, T., 1999, Infrasonic precursors to a Vulcanian eruption at Sakurajima Volcano, Japan: Geophysical Research Letters, v. 26, no. 16, p. 2537-2540.

Gardner, C.A., and White, R.A., 2002, Seismicity, gas emission and deformation from 18 July to 25 September 1995 during the initial phreatic phase of the eruption of Soufriere Hills Volcano, Montserrat, in Druitt, T.H., and Kokelaar, B.P., eds., The eruption of Soufriere Hills Volcano, Montserrat, from 1995 to 1999: Geological Society of London Memoirs, v. 21, p. 567-581.

Gerlach, T.M., Delgado, H., McGee, K.A., Doukas, M.P., Venegas, J.J., and Cárdenas, L., 1997, Application of the LI-COR $\mathrm{CO}_{2}$ analyzer to volcanic plumes; a case study, Volcán Popocatépetl, Mexico, June 7 and 10, 1995: Journal of Geophysical Research, v. 102, no. B4, p. 8005-8019.

Gerlach, T.M., Doukas, M.P., 1994, Sulfur dioxide scrubbing by water in volcanoes and implications for volcano hazards assessments based on sulfur dioxide fluxes [abs.]: Geological Society of America, Abstracts with Programs, v. 26, no. 7, p. 453.

Gerlach, T.M., McGee, K.A., and Doukas, M.P., in press, Emission rates of $\mathrm{CO}_{2}, \mathrm{SO}_{2}$, and $\mathrm{H}_{2} \mathrm{~S}$, scrubbing, and preeruption excess volatiles at Mount St. Helens, 2004-2005, chap. 26 of Sherrod, D.R., Scott, W.E., and Stauffer, P.H., eds., A volcano rekindled; the renewed eruption of Mount St. Helens, 2004-2006: U.S. Geological Survey Professional Paper 1750.

Gerlach, T.M., McGee, K.A., Sutton, A.J., and Elias, T., 1998, Rates of volcanic $\mathrm{CO}_{2}$ degassing from airborne determinations of $\mathrm{SO}_{2}$ emission rates and plume $\mathrm{CO}_{2} / \mathrm{SO}_{2}$; test study at $\mathrm{Pu}$ 'u 'O'o cone, Kilauea volcano, Hawaii: Geophysical Research Letters, v. 25, no. 14, p. 2675-2678.

Gerst, A., and Savage, M.K., 2004, Seismic anisotropy beneath Ruapehu Volcano; a possible eruption forecasting tool: Science, v. 306, p. 1543-1547.

Giampiccolo, E., Musumeci, C., Malone, S.D., Gresta, S., and Privitera, E., 1999, Seismicity and stress-tensor inversion in the central Washington Cascades mountains: Bulletin of the Seismological Society of America, v. 89, no. 3, p. 811-821.

Giggenbach, W., and Sheppard, D.S., 1989, Variations in the temperature and chemistry of White Island fumarole discharges 1972-1985: New Zealand Geological Survey Bulletin, v. 103, p. 119-126. 
Gomez M., D.M., and Torres C., R.A., 1997, Unusual low-frequency volcanic seismic events with slowly decaying coda waves observed at Galeras and other volcanoes: Journal of Volcanology and Geothermal Research, v. 77, no. 1-4, p. 173-193.

Granieri, D., Chiodini, G., Marzocchi, W., and Avino, R., 2003, Continuous monitoring of $\mathrm{CO}_{2}$ soil diffuse degassing at Phlegraean Fields (Italy); influence of environmental and volcanic parameters: Earth and Planetary Science Letters, v. 212, no. 1-2, p. 167-179.

Gret, A., Snieder, R., Aster, R.C., and Kyle, P.R., 2005, Monitoring rapid temporal change in a volcano with coda wave interferometry: Geophysical Research Letters, v. 32, no. 6, 4 p., doi:10.1029/2004GL021143.

Gunasekera, R.C., Foulger, G.R., and Julian, B.R., 2003, Reservoir depletion at The Geysers geothermal area, California, shown by four-dimensional seismic tomography: Journal of Geophysical Research, v. 108, no.B3, 11 p., doi:10.1029/2001JB000638.

Hadley, K.C., and LaHusen, R.G., 1995, Technical manual for an experimental acoustic flow monitor: U.S. Geological Survey Open-File Report 95-114, 25 p.

Hagerty, M.T., Schwartz, S.Y., Garcés, M.A., and Protti, M., 2000, Analysis of seismic and acoustic observations at Arenal Volcano, Costa Rica, 1995-1997: Journal of Volcanology and Geothermal Research, v. 101, no. 1-2, p. 27-65.

Harlow, D.H., Power, J.A., Laguerta, E.P., Ambubuyog, G., White, R.A., and Hoblitt, R.H., 1996, Precursory seismicity and forecasting of the June 15, 1991, eruption of Mount Pinatubo: in Newhall, C.S., and Punongbayan, S., Fire and mud; eruptions and lahars of Mount Pinatubo, Philippines: Seattle, University of Washington Press, p. 285-305.

Harris, A., Dehn, J., Patrick, M., Calvari, S., Ripepe, M., and Lodato, L., 2005a, Lava effusion rates from hand-held thermal infrared imagery; an example from the June 2003 effusive activity at Stromboli: Bulletin of Volcanology, v. 68, no. 2, p. 107-117.

Harris, A., Pirie, D., Horton, K., Garbeil, H., Pilger, E., Ramm, H., Hoblitt, R., Thornber, C., Ripepe, M., Marchetti, E., and Poggi, P., 2005b, DUCKS; low cost thermal monitoring units for near-vent deployment: Journal of Volcanology and Geothermal Research, v. 143, no. 4, p. 335-360.

Harris, A.J.L., Keszthelyi, L., Flynn, L.P., Mouginis-Mark, P.J., Thornber, C., Kauahikaua, J., Sherrod, D., Trusdell, F., Sawyer, M.W., and Flament, P., 1997, Chronology of the episode 54 eruption at Kîlauea Volcano, Hawaii, from GOES-9 satellite data: Geophysical Research Letters, v. 24, no. 24 , p. $3281-3284$.
Herd, R.A., Edmonds, M., and Bass, V.A., 2005, Catastrophic lava dome failure at Soufrière Hills Volcano, Montserrat, 12-13 July 2003: Journal of Volcanology and Geothermal Research, v. 148, no. 3-4, p. 234-252.

Hernández, P.A., Notsu, K., Salazar, J.M., Mori, T., Natale, G., Okada, H., Virgili, G., Shimoike, Y., Sato, M., and Perez, N.M., 2001, Carbon dioxide degassing by advective flow from Usu volcano, Japan: Science, v. 292, no. 5514, p. 83-86.

Hernández, P.A., Salazar, J.M.L., Perez, N.M., Melian, G., Herrera, M., and Strauch, W., 2002, Continuous monitoring of diffuse $\mathrm{CO}_{2}$ and $\mathrm{H}_{2} \mathrm{~S}$ degassing rates at Masaya Volcano, Nicaragua, Central America [abs.]: Eos (American Geophysical Union Transactions), v. 83, no. 7, V21B-1205.

Hidayat, D., Voight, B., Langston, C., Ratdomopurbo, A., and Ebeling, C., 2000, Broadband seismic experiment at Merapi Volcano, Java, Indonesia; very-long-period pulses embedded in multiphase earthquakes: Journal of Volcanology and Geothermal Research, v. 100, no 1-4, p. 215-231.

Hill, D.P., Bailey, R.A., and Ryall, A.S., 1985, Active tectonic and magmatic processes beneath Long Valley Caldera, Eastern California; an overview: Journal of Geophysical Research, v. 90, no. B13, p. 11111-11120.

Hill, D.P., Dawson, P.B., Johnston, M.J.S., Pitt, A.M., Biasi, G.P., and Smith, K., 2002, Very long-period volcanic earthquakes beneath Mammoth Mountain, California: Geophysical Research Letters, v. 29, no.10, 4 p.

Hill, D.P., Johnston, M.J.S., Langbein, J.O., and Bilham, R., 1995, Response of Long Valley caldera to the $\mathrm{M}_{\mathrm{w}}=7.3$ Landers, California, earthquake: Journal of Geophysical Research, v. 100, no. B7, p. 12985-13005.

Hufford, G.L., Salinas, L.J., Simpson, J.J., Barske, E.G., and Pieri, D.C., 2000, Operational implications of airborne volcanic ash: Bulletin of the American Meteorological Society, v. 81 , no. 4 , p. $745-755$.

Hurwitz, S., and Johnston, M.J.S., 2003, Groundwater level changes in a deep well in response to a magma intrusion event on Kilauea Volcano, Hawai'i: Geophysical Research Letters, v. 30, no. 22, 4p., doi:2110.1029/2003GL018676.

Hurwitz, S., Lowenstern, J.B., and Heasler, H., 2007, Spatial and temporal geochemical trends in the hydrothermal system of Yellowstone National Park; inferences from river solute fluxes: Journal of Volcanology and Geothermal Research, v. 162, no. 3-4, p. 149-171.

Iwashita, S., Takahashi, H., Okazaki, N., Miyamura, J., Kasahara, M., Ichiyanagi, M., Takahashi, R., and Nakagawa, M., 2005, Volcanic inflation of Mount HokkaidoKomagatake, Japan, determined from a dense GPS 
array: Geophysical Research Letters, v. 32, no. 20, 4p., doi:20310.21029/22005GL023438.

Iwatsubo, E.Y., Ewert, J.W., and Murray, T.L., 1992, Monitoring radial crack deformation by displacement meters, in Ewert, J., and Swanson, D., eds., Monitoring volcanoes; techniques and strategies used by the staff of the Cascades Volcano Observatory, 1980-90: U.S. Geological Survey Bulletin 1966, p. 95-101.

Janda, R.J., Scott, K.M., Nolan, K.M., and Martinson, H.A., 1981, Lahar movement, effects, and deposits: in Lipman, P.W., and Mullineaux, D.R., eds., The 1980 eruptions of Mount St. Helens: U.S. Geological Survey Professional Paper 1250, p. 461-478.

Ji, C., Larson, K.M., Tan, Y., Hudnut, K.W., and Choi, K., 2004, Slip history of the 2003 San Simeon earthquake constrained by combining 1-Hz GPS, strong motion, and teleseismic data: Geophysical Research Letters, v. 31, no. 17, 4p., doi:17610.11029/12004GL020448.

Johnson, J.B., and Aster, R.C., 2005, Relative partitioning of acoustic and seismic energy during Strombolian eruptions: Journal of Volcanology and Geothermal Research, v. 148, no. 3-4, p. 334-354.

Johnson, J.B., Aster, R.C., and Kyle, P.R., 2004, Volcanic eruptions observed with infrasound: Geophysical Research Letters, v. 31, L14604, 4 p., doi:10.1029/2004GL020020.

Johnson, J.B., and Lees, J.M., 2000, Plugs and chugs-seismic and acoustic observations of degassing explosions at Karymsky, Russia and Sangay, Ecuador: Journal of Volcanology and Geothermal Research, v. 101, no. 1-2, p. 67-82.

Jousset, P., Dwipa, S., Beauducel, F., Duquesnoy, T., and Diament, M., 2000, Temporal gravity at Merapi during the 1993-1995 crisis: an insight into the dynamical behaviour of volcanoes: Journal of Volcanology and Geothermal Research, v. 100, no. 1-4, p. 289-320.

Julian, B., Miller, A.D., and Foulger, G.R., 1998, Non-doublecouple earthquakes: 1 . Theory: Reviews of Geophysics, v. 36 , p. 525-549.

Kinoshita, W.T., Swanson, D.A., and Jackson, D.B., 1974, The measurement of crustal deformation related to volcanic activity at Kilauea Volcano, Hawaii, Developments in Solid Earth Geophysics 6, Physical Volcanology, p. 87-115.

Klein, F., and Koyanagi, R.Y., 1989, The seismicity and tectonics of Hawaii, in Winterer, E.L., Hussong, D.M., and Decker, R.W., eds., The eastern Pacific Ocean and Hawaii: Denver, Colo., Geological Society of America, p. 238-252.

Kobayashi, T., Ohminato, T., and Ida, Y., 2003, Earthquake series preceding very long period seismic signals, observed during the 2000 Miyakejima volcanic activ- ity: Geophysical Research Letters, v. 30, no. 8, 4 p., doi:10.1029/2002GL016631.

Krueger, A.J., 1995, Volcanic sulfur dioxide measurements from the total ozone mapping spectrometer instruments: Journal of Geophysical Research, v. 100, no. D7, p. 14057-14076

Kumagai, H., and Chouet, B.A., 2000, Acoustic properties of a crack containing magmatic or hydrothermal fluids: Journal of Geophysical Research, v. 105, no. B11, p. 25493-25512.

Kumagai, H., Ohminato, T., Nakano, M., Ooi, M., Kubo, A., Inoue, H., and Oikawa, J., 2001, Very-long-period seismic signals and caldera formation at Miyake Island, Japan: Science, v. 293, p. 687-690.

Lacasse, C., Karlsdottir, S., Larsen, G., Soosalu, H., Rose, W.I., and Ernst, G.G.J., 2004, Weather radar observations of the Hekla 2000 eruption cloud, Iceland: Bulletin of Volcanology, v. 66 , no. 5, p. 457-473.

Lahr, J.C., Chouet, B.A., Stephens, C.D., Power, J.A., and Page, R.A., 1994, Earthquake classification, location, and error analysis in a volcanic environment; implications for the magmatic system of the 1989-1990 eruptions at Redoubt Volcano, Alaska: Journal of Volcanology and Geothermal Research, v. 62, no. 1-4, p. 137-151.

LaHusen, R.G., Swinford, K.J., Logan, M., and Lisowski, M., in press, Instrumentation in remote and dangerous settings: an example from GPS "spider" deployments during the 2004-2005 eruption of Mount St. Helens, chap. 16 of Sherrod, D.R., Scott, W.E., and Stauffer, P.H., eds., A volcano rekindled; the renewed eruption of Mount St. Helens, 2004-2006: U.S. Geological Survey Professional Paper 1750.

Langbein, J.O., 2006, Evaluation of some software measuring displacements using GPS in real-time: U.S. Geological Survey Open-File Report 2006-1235, 32 p.

Langbein, J.O., Hill, D.P., Parker, T.N., and Wilkinson, S.K., 1993, An episode of reinflation of the Long Valley Caldera, eastern California; 1989-1991: Journal of Geophysical Research, v. 98, no. B9, p. 15851-15870.

Larson, K.M., Bodin, P., and Gomberg, J., 2003, Using 1-Hz GPS data to measure deformations caused by the Denali fault earthquake: Science, v. 300, no. 5624, p. 1421-1424.

Larson, K.M., Lowry, A.R., Kostoglodov, V., Hutton, W., Sánchez, O., Hudnut, K., and Suárez, G., 2004, Crustal deformation measurements in Guerrero, Mexico: Journal of Geophysical Research, v. 109, no. B4, doi:10.1029/2003JB002843.

Lavigne, F., Thouret, J.-C., Voight, B., Young, K., LaHusen, R., Marso, J., Suwa, H., Sumaryono, A., Sayudi, D.S., and 
Dejean, M., 2000, Instrumental lahar monitoring at Merapi Volcano, Central Java, Indonesia: Journal of Volcanology and Geothermal Research, v. 100, no. 1-4, p. 457-478

Lees, J.M., Gordeev, E.I., and Ripepe, M., 2004, Explosions and periodic tremor at Karymsky volcano, Kamchatka: Geophysical Journal International, v. 158, no. 3, p. 1151-1167.

Lesage, P., and Surono, 1995, Seismic precursors of the February 10, 1990 eruption of Kelut volcano, Java: Journal of Volcanology and Geothermal Research, v. 65, no. 1-2, p. 135-146.

Linde, A.T., Agustsson, K., Sacks, I.S., and Stefansson, R., 1993, Mechanism of the 1991 eruptions of Hekla from continuous borehole strain monitoring: Nature, v. 365, no. 6448, p. 737-740.

Lipman, P.W., Moore, J.G., and Swanson, D.A., 1981, Bulging of the north flank before the May 18 eruption - geodetic data, in Lipman, P.W., and Mullineaux, D.R., eds., The 1980 eruptions of Mount St. Helens, Washington: U.S. Geological Survey Professional Paper 1250, p. 143-155.

Lockhart, A.B., and Murray, T.L., 2003, The Mount Rainier lahar detection system [abs.]: Eos (American Geophysical Union Transactions), v. 84, no. 47, V51F-0343.

Londoño, B.J.M., Sánchez, A.J.J., Toro, E.L.E., Gil Cruz, F., and Rodriguez, O.P., 1998, Coda Q before and after the eruptions of 13 November 1985, and 1 September 1989, at Nevado del Ruiz volcano, Colombia: Bulletin of Volcanology, v. 59, p. 556-561.

Lowenstern, J.B., Smith, R.B., and Hill, D.P., 2006, Monitoring super-volcanoes: geophysical and geochemical signals at Yellowstone and other large caldera systems: Royal Society of London Philosophical Transactions, ser. A, v. 364, p. 2055-2072.

Lu, Z., Wicks C., Jr., Dzurisin, D., Power, J.A., Moran, S.C., and Thatcher, W., 2002, Magmatic inflation at a dormant stratovolcano; 1996-1998 activity at Mount Peulik volcano, Alaska, revealed by satellite radar interferometry: Journal of Geophysical Research, v. 107, no. B7, 13p., doi:2110.1029/2001JB000471.

Major, J.J., Janda, R.J., and Daag, A.S., 1996, Watershed disturbance and lahars on the east side of Mount Pinatubo during the mid-June 1991 eruptions, in Newhall, C.S., and Punongbayan, S., eds., Fire and mud; eruptions and lahars of Mount Pinatubo, Philippines: Seattle, University of Washington Press, p. 895-919.

Major, J.J., Kingsbury, C.G., Poland, M.P., and LaHusen, R.G., in press, Extrusion rate of the Mount St. Helens lava dome estimated from terrestrial imagery; November 2004-December 2005, chap. 12 of Sherrod, D.R., Scott,
W.E., and Stauffer, P.H., eds., A volcano rekindled; the renewed eruption of Mount St. Helens, 2004-2006: U.S. Geological Survey Professional Paper 1750.

Malone, S.D., Boyko, C., and Weaver, C.S., 1983, Seismic precursors to the Mount St. Helens eruptions in 1981 and 1982: Science, v. 221, p. 1376-1378.

Malone, S.D., Endo, E.T., Weaver, C.S., and Ramey, J.W., 1981, Seismic monitoring for eruption prediction: in Lipman, P.W., and Mullineaux, D.R., eds., The 1980 eruptions of Mount St. Helens: U.S. Geological Survey Professional Paper 1250, p. 803-813.

Marcial, S.S., Melosantos, A.A., Hadley, K.C., LaHusen, R.G., and Marso, J.N., 1996, Instrumental lahar monitoring at Pinatubo Volcano, in Newhall, C.S., and Punongbayan, S., eds., Fire and mud; eruptions and lahars of Mount Pinatubo, Philippines: Seattle, University of Washington Press, p. 1015-1022.

Massonnet, D., Briole, P., and Arnaud, A., 1995, Deflation of Mount Etna monitored by spaceborne radar interferometry: Nature, v. 375, no. 6532, p. 567-570.

Matoza, R.S., Hedlin, M.A.H., and Garcés, M.A., 2007, An infrasound array study of Mount St. Helens: Journal of Volcanology and Geothermal Research, v. 160, no. 3-4, p. 249-262.

Mattioli, G.S., Young, S.R., Voight, B., Sparks, R.S.J., Shalev, E., Sacks, S., Malin, P., Linde, A, Johnston, W., Hidayat, D., Elsworth, D., Dunkley, P, Herd, R., Neuberg, J., Norton, G., and Widiwijayanti, C., 2004, Prototype PBO instrumentation of CALIPSO project captures world-record lava dome collapse on Montserrat Volcano: Eos (American Geophysical Union Transactions), v. 85, no. 34, p. 317, 323, 325.

McConnell, V.S., Shearer, C.K., Eichelberger, J.C., Keskinen, M.J., Layer, P.W., and Papike, J.J., 1995, Rhyolite intrusions in the intracaldera Bishop Tuff, Long Valley Caldera, California: Journal of Volcanology and Geothermal Research, v. 67, no. 1-3, p. 41-60.

McGee, K.A., and Casadevall, T.J., 1994, A compilation of sulfur dioxide and carbon dioxide emission-rate data from Mount St. Helens during 1980-88: U.S. Geological Survey Open-File Report 94-0212, 23 p.

McGee, K.A., Doukas, M.P., and Gerlach, T.M., 2001, Quiescent hydrogen sulfide and carbon dioxide degassing from Mount Baker, Washington: Geophysical Research Letters, v. 28, no. 23, p. 4479-4483.

McGee, K.A., Gerlach, T.M., Kessler, R., and Doukas, M.P., 2000, Geochemical evidence for a magmatic $\mathrm{CO}_{2}$ degassing event at Mammoth Mountain, California, SeptemberDecember 1997: Journal of Geophysical Research, v. 105, no. B4, p. 8447-8456. 
McNutt, S.R., 1994, Volcanic tremor amplitude correlated with eruption explosivity and its potential use in determining ash hazards to aviation, in Casadevall, T.J., ed., Volcanic ash and aviation safety: U.S. Geological Survey Bulletin 2047, p. 377-385.

McNutt, S.R., Tytgat, G.C., and Power, J.A., 1995, Preliminary analyses of volcanic tremor associated with 1992 eruptions of Crater Peak, Mount Spurr Volcano, Alaska, in Keith, T.E.C., ed., The 1992 eruptions of Crater Peak vent, Mount Spurr volcano, Alaska: U.S. Geological Survey Bulletin 2139, p. 161-177.

Miklius, A., and Cervelli, P., 2003, Interaction between Kilauea and Mauna Loa: Nature, v. 421, no. 6920, p. 229.

Miller, T.P., and Casadevall, T.J., 2000, Volcanic ash hazards to aviation: in H. Sigurdsson, ed., Encyclopedia of volcanoes: San Diego, Calif., Academic Press, p. 915-930.

Miller, V., and Savage, M., 2001, Changes in seismic anisotropy after volcanic eruptions; evidence from Mount Ruapehu: Science, v. 293, p. 2231-2233.

Miyazaki, S., Larson, K., Choi, K., Hikima, K., Koketsu, K., Bodin, P., Haase, J., Emore, G., and Yamagiwa, A., 2004, Modeling the rupture process of the 2003 Tokachi-Oki (Hokkaido) earthquake using 1-Hz GPS data: Geophysical Research Letters, v. 31, no. 21, 4p., doi:10.1029/2004GL021457.

Mogi, K., 1958, Relations between the eruptions of various volcanoes and the deformations of the ground surfaces around them: Earthquake Research Institute Bulletin, v. 36, no. 2, p. 99-134.

Moran, S.C., 1994, Seismicity at Mount St. Helens, 1987-1992; evidence for repressurization of an active magmatic system: Journal of Geophysical Research, v. 99, no. B3, p. 4341-4354.

Moran, S.C., Malone, S.D., Qamar, A.I., Thelen, W., Wright, A., and Caplan-Auerbach, J., in press a, Seismicity associated with renewed dome-building at Mount St. Helens, 2004-2005, chap. 2 of Sherrod, D.R., Scott, W.E., and Stauffer, P.H., eds., A volcano rekindled; the renewed eruption of Mount St. Helens, 2004-2006: U.S. Geological Survey Professional Paper 1750.

Moran, S.C., McChesney, P.J., and Lockhart, A.B., in press $\mathrm{b}$, Seismicity and infrasound associated with explosions at Mount St. Helens, 2004-2005, chap. 6 of Sherrod, D.R., Scott, W.E., and Stauffer, P.H., eds., A volcano rekindled; the renewed eruption of Mount St. Helens, 2004-2006: U.S. Geological Survey Professional Paper 1750.

Murray, T.L., Nye, C.J., and Eichelberger, J.C., 2006, Use of new and old technologies and methods by the Alaska
Volcano Observatory during the 2006 eruption of Augustine Volcano, Alaska [abs.]: Eos (American Geophysical Union Transactions), v. 87, no. 52, V51C-1696.

Nakada, S., and Eichelberger, J., 2004, Looking into a volcano; drilling Unzen: Geotimes, v. 49, no. 3, p. 14-17.

Nakada, S., Sakuma, S., Uto, K., Shimizu, H., and Eichelberger, J.C., 2004, Real images of magmatic conduit: progress of the conduit drilling in Unzen [abs.]: Eos (American Geophysical Union Transactions), v. 85, no. 47, V24B-06.

Nakada, S., Nagai, M., Kaneko, T., Nozawa, A., and SuzukiKamata, K., 2005, Chronology and products of the 2000 eruption of Miyakejima Volcano, Japan: Bulletin of Volcanology, v. 67, p. 205-218.

Nakano, M., Kumagai, H., and Chouet, B.A., 2003, Source mechanism of long-period events at Kusatsu-Shirane Volcano, Japan, inferred from waveform inversion of the effective excitation functions: Journal of Volcanology and Geothermal Research, v. 122, no. 3-4, p. 149-164.

Neal, C.A., Casadevall, T.J., Miller, T.P., Hendley J.W., II, and Stauffer, P.H., 1997, Volcanic ash-danger to aircraft in the North Pacific: U.S. Geological Survey Fact Sheet 030-97, $2 \mathrm{p}$.

Newhall, C.G., Albano, S.E., Matsumoto, N., and Sandoval, T., 2001, Roles of groundwater in volcanic unrest: Geological Society of the Philippines Journal, v. 56, no. 3-4, p. 69-84.

Nishimura, T., Sadato, U., Yamawaki, T., Tanaka, S., Hashino, H., Sato, M., Nakamichi, H., and Hamaguchi, H., 2003, Broadband seismic signals associated with the 2000 volcanic unrest of Mount Bandai, northeastern Japan: Journal of Volcanology and Geothermal Research, v. 119, no. 1-4, p. 51-59.

Nishimura, T., Tanaka, S., Yamawaki, T., Yamamoto, H., Sano, T., Sato, M., Nakahar, H., Uchida, N. Hori, S., and Sato, H., 2005, Temporal changes in seismic velocity of the crust around Iwate volcano, Japan, as inferred from analyses of repeated active seismic experiment data from 1998 to 2003: Earth, Planets, and Space, v. 57, p. 491-505.

Notsu, K., Mori, T., Hernández, P.A., Virgili, G., Salazar, J.M.L., Perez, N.M., and Okada, H., 2000, Continuous monitoring of soil $\mathrm{CO}_{2}$ diffuse emissions at Usu Volcano, Hokkaido, Japan [abs.]: Eos (American Geophysical Union Transactions), v. 81, no. 48, p. 1320-1321.

Novelo-Casanova, D.A., Martinez-Bringas, A., and ValdesGonzalez, C., 2006, Temporal variations of Qc-1 and b-values associated to the December 2000-January 2001 volcanic activity at the Popocatepetl volcano, Mexico: Journal of Volcanology and Geothermal Research, v. 152, no. 3-4, p. 347-358. 
Nye, C.J., Keith, T.E.C., Eichelberger, J.C., Miller, T.P., McNutt, S.R., Moran, S., Schneider, D.J., Dehn, J., and Schaefer, J.R., 2002, The 1999 eruption of Shishaldin Volcano, Alaska; monitoring a distant eruption: Bulletin of Volcanology, v. 64, no. 8, p. 507-519.

Ohminato, T., Takeo, M., Kumagai, H., Yamashina, T., Oikawa, J., Koyama, E., Tsuji, H., and Urabe, T., 2006, Vulcanian eruptions with dominant single force components observed during the Asama 2004 volcanic activity in Japan: Earth, Planets, Space, v. 58, p. 583-593.

Okada, Y., 1985, Surface deformation due to shear and tensile faults in a half-space: Bulletin of the Seismological Society of America, v. 75, no. 4, p. 1135-1154.

Omori, F., 1911, The Usu-san eruption and earthquake elevation phenomena: Imperial Earthquake Investigation Committee Bulletin, v. 5, no. 1, p. 1-38.

Owen, S., Segall, P., Freymueller, J.T., Miklius, A., Denlinger, R.P., Arnadottir, T., Sako, M.K., and Bürgmann, R., 1995, Rapid deformation of the south flank of Kilauea Volcano, Hawaii: Science, v. 267, no. 5202, p. 1328-1332.

Owen, S., Segall, P., Lisowski, M., Miklius, A., Denlinger, R., and Sako, M., 2000a, Rapid deformation of Kilauea Volcano; Global Positioning System measurements between 1990 and 1996: Journal of Geophysical Research, v. 105, no. B8, p. 18983-18993.

Owen, S., Segall, P., Lisowski, M., Miklius, A., Murray, M., Bevis, M., and Foster, J., 2000b, January 30, 1997 eruptive event on Kilauea Volcano, Hawaii, as monitored by continuous GPS: Geophysical Research Letters, v. 27, no. 17, p. 2757-2760.

Pagli, C., Sigmundsson, F., Arnadottir, T., Einarsson, P., and Sturkell, E., 2006, Deflation of the Askja volcanic system; constraints on the deformation source from combined inversion of satellite radar interferograms and GPS measurements: Journal of Volcanology and Geothermal Research, v. 152, no. $1-2$, p. $97-108$.

Pallister, J.S., Thornber, C.R., Cashman, K.V., Clynne, M.A., Lowers, H.A., Mandeville, C.W., Brownfield, I.K., and Meeker, G.P., in press, Petrology of the 2004-2006 Mount St. Helens lava dome-implications for magmatic plumbing and eruption triggering, chap. 30 of Sherrod, D.R, Scott, W.E., and Stauffer, P.H., eds., A volcano rekindled; the renewed eruption of Mount St. Helens, 2004-2006: U.S. Geological Survey Professional Paper 1750.

Patrick, M.R., Dehn, J., Papp, K.R., Lu, Z., Dean, K., Moxey, L., Izbekov, P., and Guritz, R., 2003, The 1997 eruption of Okmok Volcano, Alaska; a synthesis of remotely sensed imagery: Journal of Volcanology and Geothermal Research, v. 127 , no. $1-2$, p. $87-105$.
Peltier, A., Staudacher, T., Catherine, P., Ricard, L.-P., Kowalski, P., and Bachèlery, P., 2006, Subtle precursors of volcanic eruptions at Piton de la Fournaise detected by extensometers: Geophysical Research Letters, v. 33, no. 6, 5 p., doi:10.1029/2005GL025495.

Pierson, T.C., Daag, A.S., Reyes, P.J.D., Regalado, M.T.M., Solidum, R.U., and Tubianosa, B.S., 1996, Flow and deposition of posteruption hot lahars on the east side of Mount Pinatubo, July-October 1991, in Newhall, C.S., and Punongbayan, S., eds., Fire and mud; eruptions and lahars of Mount Pinatubo, Philippines: Seattle, University of Washington Press, p. 921-950.

Poland, M.P., Bürgmann, R., Dzurisin, D., Lisowski, M., Masterlark, T., Owen, S., and Fink, J.H., 2006, Constraints on the mechanism of long-term, steady subsidence at Medicine Lake volcano, northern California, from GPS, leveling, and InSAR: Journal of Volcanology and Geothermal Research, v. 150 , no. $1-3$, p. $55-78$.

Poland, M.P., Dzurisin, D., LaHusen, R.G., Major, J.J., Lapcewich, D., Endo, E.T., Gooding, D., Schilling, S.P., and Janda, C., in press, Photographic documentation of lava dome growth at Mount St. Helens, Washington, October 2004-February 2006, chap. 11 of Sherrod, D.R, Scott, W.E., and Stauffer, P.H., eds., A volcano rekindled; the renewed eruption of Mount St. Helens, 2004-2006: U.S. Geological Survey Professional Paper 1750.

Power, J.A., 1988, Seismicity associated with the 1986 eruption of Augustine Volcano, Alaska: Fairbanks, University of Alaska, M.S. thesis, 142 p.

Power, J.A., Jolly, A.D., Page, R.A., and McNutt, S.R., 1995, Seismicity and forecasting of the 1992 eruptions of Crater Peak vent, Mount Spurr volcano, Alaska; an overview, in Keith, T.E.C., ed., The 1992 eruptions of Crater Peak vent, Mount Spurr volcano: U.S. Geological Survey Bulletin 2139, p. 149-159.

Power, J.A., Stihler, S.D., Dixon, J.P., Moran, S.C., CaplanAuerbach, J., Prejean, S., McGee, K., Doukas, M, and Roman, D., 2004a, Renewed seismic unrest at Mount Spurr volcano, Alaska in 2004; evidence for a magmatic intrusion [abs.]: Eos (American Geophysical Union Transactions), v. 85, no. 47, S51A-0143.

Power, J.A., Stihler, S.D., White, R.A., Moran, S.C., 2004b, Observations of deep long-period (DLP) seismic events beneath Aleutian arc volcanoes; 1989-2002: Journal of Volcanology and Geothermal Research, v. 138, no. 3-4, p. 243-266.

Prata, A.J., 1989, Observations of volcanic ash clouds in the 10-12 $\mu \mathrm{m}$ window using AVHRR/2 data: International Journal of Remote Sensing, v. 10, no. 4-5, p. 751-761. 
Prejean, S.G., and Ellsworth, W.L., 2001, Observations of earthquake source parameters at $2 \mathrm{~km}$ depth in the Long Valley Caldera, Eastern California: Bulletin of the Seismological Society of America, v. 81, p 165-177.

Prejean, S.G., Stork, A., Ellsworth, W., Hill, D., and Julian, B., 2003, High precision earthquake locations reveal seismogenic structure beneath Mammoth Mountain, California: Geophysical Research Letters, v. 30, no. 24, 4 p., doi:10.1029/2003GL018334.

Pribnow, D.F.C., Schütze, C., Hurter, S.J., Flechsig, C., and Sass, J.H., 2003, Fluid flow in the resurgent dome of Long Valley Caldera; implications from thermal data and deep electrical sounding: Journal of Volcanology and Geothermal Research, v. 127, no. 3-4, p. 329-345.

Ramsey, M., and Dehn, J., 2004, Spaceborne observations of the 2000 Bezymianny, Kamchatka eruption; the integration of high-resolution ASTER data into near real-time monitoring using AVHRR: Journal of Volcanology and Geothermal Research, v. 135, no. 1-2, p. 127-146.

Reid, M.E., Sisson, T.W., and Brien, D.L., 2001, Volcano collapse promoted by hydrothermal alteration and edifice shape, Mount Rainier, Washington: Geology, v. 29, no. 9, p. 779-782.

Roeloffs, E., Sneed, M., Galloway, D.L., Sorey, M.L., Farrar, C.D., Howle, J.F., and Hughes, J., 2003, Water-level changes induced by local and distant earthquakes at Long Valley caldera, California: Journal of Volcanology and Geothermal Research, v. 127, no. 3-4, p. 269-303.

Rogie, J.D., Kerrick, D.M., Sorey, M.L., Chiodini, G., and Galloway, D.L., 2001, Dynamics of carbon dioxide emission at Mammoth Mountain, California: Earth and Planetary Science Letters, v. 188, no. 3-4, p. 535-541.

Rolandi, G., Barrella, A.M., and Borrelli, A., 1993, The 1631 eruption of Vesuvius: Journal of Volcanology and Geothermal Research, v. 58, no. 1-4, p. 183-201.

Roman, D.C., Moran, S.C., Power, J.A., and Cashman, K.V., 2004, Temporal and spatial variation of local stress fields before and after the 1992 eruptions of Crater Peak Vent, Mount Spurr Volcano, Alaska: Bulletin of the Seismological Society of America, v. 94, p. 2366-2379.

Rose, W.I., Kostinski, A.B., and Kelley, L., 1995, Real-time C-band radar observations of 1992 eruption clouds from Crater Peak, Mount Spurr volcano, Alaska, in Keith, T.E.C., ed., The 1992 eruptions of Crater Peak vent, Mount Spurr volcano, Alaska: U.S. Geological Survey Bulletin 2139, p. $19-26$.

Rosen, P.A., Hensley, S., Zebker, H.A., Webb, F.H., and Fielding, E.J., 1996, Surface deformation and coherence measurements of Kilauea Volcano, Hawaii, from SIR-C radar interferometry: Journal of Geophysical Research, v. 101, no. E10, p. 23109-23125.

Rosi, M., Principe, C., and Vecci, R., 1993, The 1631 Vesuvius eruption. A reconstruction based on historical and stratigraphical data: Journal of Volcanology and Geothermal Research, v. 58, no. 1-4, p. 151-182.

Rowe, C.A., Aster, R.C., Kyle, P.R., Dibble, R.R., and Schlue, J.W., 2000, Seismic and acoustic observations at Mount Erebus Volcano, Ross Island, Antarctica, 1994-1998: Journal of Volcanology and Geothermal Research, v. 101, no. 1, p 105-128.

Rowe, C.A., Thurber, C.H., and White, R.A., 2004, Dome growth behavior at Soufriere Hills Volcano, Montserrat, revealed by relocation of volcanic event swarms, 1995-1996: Journal of Volcanology and Geothermal Research, v. 134, no. 3, p. 199-221.

Rymer, H., and Brown, G.C., 1989, Gravity changes as a precursor to volcanic eruption at Poas volcano, Costa Rica: Nature, v. 342 , no. 6252 , p. 902-905.

Sacks, I.S., Suyehiro, S., Evertson, D.W., and Yamagishi, Y., 1971, Sacks-Evertson strainmeters, its installation in Japan and some preliminary results concerning strain steps: Papers in Meteorology and Geophysics, v. 22, no. 3-4, p. 195-208.

Sánchez, J.J., Wyss, M., and McNutt, S.R., 2004, Temporalspatial variations of stress at Redoubt volcano, Alaska, inferred from inversion of fault plane solutions: Journal of Volcanology and Geothermal Research, v. 130, no. 1-2, p. $1-30$.

Sandoval, T., Newhall, C., Corpuz, E., Laguerta, E., Balaloy, A., and Toledo, R., 2000, Response of spring discharge to 1999-2000 unrest of Mayon volcano, Philippines [abs.]: Eos (American Geophysical Union Transactions), v. 81, no. 52, p. WP44.

Schilling, S.P., 1998, LAHARZ; GIS programs for automated mapping of lahar-inundation hazard zones: U.S. Geological Survey Open-File Report 98-638, 80 p.

Schilling, S.P., Thompson, R.A., Messerich, J.A., and Iwatsubo, E.Y., in press, Mount St. Helens lava dome growth and surface modeling, 2004-2005, chap. 8 of Sherrod, D.R., Scott, W.E., and Stauffer, P.H., eds., A volcano rekindled; the renewed eruption of Mount St. Helens, 2004-2006: U.S. Geological Survey Professional Paper 1750.

Schneider, D.J., Dean, K.G., Dehn, J., Miller, T.P., and Kirianov, V.Y., 2000, Monitoring and analyses of volcanic activity using remote sensing data at the Alaska Volcano Observatory; case study of Kamchatka, Russia, December 1997, in Mouginis-Mark, P.J., Crisp, J.A., and Fink, J.H., eds., Remote sensing of active volcanism: American Geophysical Union Geophysical Monograph 116, p. 65-85. 
Scott, W.E., 1989, Volcanic and related hazards, chap. 2 of Tilling, R.I., ed., Volcanic hazards (Short Course in Geology, v. 1): Washington, D.C., American Geophysical Union, p. $9-23$.

Segall, P., Desmarais, E.K., Shelly, D., Miklius, A., and Cervelli, P., 2006, Earthquakes triggered by silent slip events on Kîlauea volcano, Hawaii: Nature, v. 442, no. 7098, p. 71-74.

Sentman, D., McNutt, S., Reyes, C., Stenbaek-Nielsen, H., and DeRoin, N., 2006, Nighttime near infrared observations of Augustine volcano Jan-Apr 2006 recorded with a small astronomical CCD camera [abs.]: Eos (American Geophysical Union Transactions), v. 87, no. 52, V42B-03.

Shibata, T., and Akita, F., 2001, Precursory changes in well water level prior to the March, 2000 eruption of Usu volcano, Japan: Geophyiscal Research Letters, v. 28, no. 9, p. 1799-1802.

Shinohara, H., 2005, A new technique to estimate volcanic gas composition; plume measurements with a portable multisensor system: Journal of Volcanology and Geothermal Research, v. 143, no. 4, p. 319-333.

Shinohara, H., Kazahaya, K., Saito, G., Fukui, K., and Odai, M., 2003, Variation of CO2/SO2 ratio in volcanic plumes of Miyakejima: Stable degassing deduced from heliborne measurements: Geophysical Research Letters, v. 30, no. 5, 1208, 4 p., doi:10.1029/2002GL016105.

Snoke, J. A., 2003, FOCMEC; FOcal MEChanism determinations, chap 85.12 of Lee, W.H.K., Kanamori, H., Jennings, P.C., and Kisslinger, C., eds., International handbook of earthquake and engineering seismology: San Diego, Calif., Academic Press, p. 1629-1630.

Sorey, M.L., Hill, D.P., and McConnell, V.S., 2000, Scientific drilling in Long Valley caldera, California - an update: California Geology, v. 53, p. 4-11.

Sparks, R.S.J., 2003, Forecasting volcanic eruptions: Earth and Planetary Science Letters, v. 210, no. 1-2, p. 1-15.

Sutton, A.J., Elias, T., Gerlach, T.M., and Stokes, J.B., 2001, Implications for eruptive processes as indicated by sulfur dioxide emissions from Kīlauea Volcano, Hawai i, 1979-1997: Journal of Volcanology and Geothermal Research, v. 108, no. 1-4, p. 283-302.

Sutton, A.J., McGee, K.A., Casadevall, T.J., and Stokes, J.B., 1992, Fundamental volcanic-gas-study techniques; an integrated approach to monitoring, in Ewert, J.W., and Swanson, D.A., eds., Monitoring volcanoes; techniques and strategies used by the staff of the Cascades Volcano Observatory, 1980-90: U.S. Geological Survey Bulletin 1966, p. 181-188.
Swanson, D.A., Casadevall, T.J., Dzurisin, D., Malone, S.D., Newhall, C.G., and Weaver, C.S., 1983, Predicting eruptions at Mount St. Helens, June 1980 through December 1982: Science, v. 221, no. 4618, p. 1369-1376.

Symonds, R.B., Gerlach, T.M. and Reed, M.H., 2001, Magmatic gas scrubbing; implications for volcano monitoring: Journal of Volcanology and Geothermal Research, v. 108, no. $1-4$, p. 303-341.

Takagi, N., Kaneshima, S., Kawakatsu, H., Yamamoto, M., Sudo, Y., Ohkura, T., Yoshikawa, S., and Mori, T., 2006, Apparent migration of tremor source synchronized with the change in the tremor amplitude observed at Aso volcano, Japan: Journal of Volcanology and Geothermal Research, v. 154, no. 3-4, p. 181-200.

Takano, B., and Watanuki, B., 1990, Monitoring of volcanic eruptions at Yugama crater lake by aqueous sulfur oxyanions: Journal of Volcanology and Geothermal Research, v. 40 , no. 1, p. 71-87.

Thelen, W., Crosson, R.S., and Creager, K.C., in press, Absolute and relative locations for earthquakes at Mount St. Helens using continuous data; implications for magmatic processes, chap. 4 of Sherrod, D.R., Scott, W.E., and Stauffer, P.H., eds., A volcano rekindled; the renewed eruption of Mount St. Helens, 2004-2006: U.S. Geological Survey Professional Paper 1750.

Thompson, G., McNutt, S.R., and Tytgat, G., 2002, Three distinct regimes of volcanic tremor associated with the eruption of Shishaldin Volcano, Alaska 1999: Bulletin of Volcanology, v. 64, p. 535-547.

Thornber, C., 1997, HVO/RVTS-1; a prototype remote video telemetry system for monitoring the Kilauea East Rift zone eruption, 1997: U.S. Geological Survey Open-File Report 97-537, 18 p.

Tilling, R.I., 1989, Measures of little gravity: Nature, v. 342, p. $862-863$

Tikku, A.A., McAdoo, D.C., Schenewerk, M.S., and Willoughby, E.C., 2006, Temporal fluctuations of microseismic noise in Yellowstone's Upper Geyser Basin from a continuous gravity observation: Geophysical Research Letters, v. 33, no. 11, doi:11310.11029/12006GL026113.

Topinka, L., 1992, Basic photography at Mount St. Helens and other Cascade volcanoes, in Ewert, J., and Swanson, D.A., eds., Monitoring volcanoes; techniques and strategies used by the staff of the Cascades Volcano Observatory, 1980-90: U.S. Geological Survey Bulletin 1966, p. 195-217.

Uto, K., Nakada, S., Shimizu, H., Sakuma, S., and Hoshizumi, H., 2004, Overview and the achievement of the Unzen Scientific Drilling Project [abs.]: Eos (American Geophysical Union Transactions), v. 85, no. 47, V24B-01. 
Vaughan, R.G., Hook, S.J., Ramsey, M.S., Realmuto, V.J., and Schneider, D.J., 2005, Monitoring eruptive activity at Mount St. Helens with TIR image data: Geophysical Research Letters, v. 32, no. 19, 4 p., doi:10.1029/2005GL024112.

Vinciguerra, S., 2002, Damage mechanics preceding the September-October 1989 flank eruption at Mount Etna volcano inferred by seismic scaling exponents: Journal of Volcanology and Geothermal Research, v. 113, no. 3-4, p. 391-397.

Voight, B., Linde, A.T., Sacks, I.S., Mattioli, G.S., Sparks, R.S.J., Elsworth, D., Hidayat, D., Malin, P.E., Shaleve, E., Widiwijayanti, C., Young, S.R., Bass, V., Clarke, A., Dunkley, P., Johnston, W., McWhorter, Neuberg, J., and Williams, P., 2006, Unprecedented pressure increase in deep magma reservoir triggered by lava-dome collapse: Geophysical Research Letters, v. 33, no. 3, 4 p., doi:10.1029/2005GL024870.

Wadge, G., Macfarlane, D.G., Robertson, D.A., Hale, A.J., Pinkerton, H., Burrell, R.V., Norton, G.E., and James, M.R., 2005, AVTIS; a novel millimetre-wave ground based instrument for volcano remote sensing: Journal of Volcanology and Geothermal Research, v. 146, no. 4, p. 307-318.

Wadge, G., Mattioli, G.S., and Herd, R.A., 2006, Ground deformation at Soufrière Hills Volcano, Montserrat during 1998-2000 measured by radar interferometry and GPS: Journal of Volcanology and Geothermal Research, v. 152, no. 1-2, p. 157-173.

Waite, G.P., Chouet, B.A., and Dawson, P.B., 2008, Eruption dynamics at Mount St. Helens imaged from inversion of broadband waveforms: interaction of the shallow magmatic and hydrothermal system: Journal of Geophysical Research, v. 113, no. B02305, 22 p, doi:10.1029/2007JB005259.

Watson, I.M., Realmuto, V.J., Rose, W.I., Prata, A.J., Bluth, G.J.S., Gu, Y., Bader, C.E., and Yu, T., 2004, Thermal infrared remote sensing of volcanic emissions using the moderate resolution imaging spectroradiometer: Journal of Volcanology and Geothermal Research, v. 135, no. 1-2, p. 75-89.

Werner, C.A., Christenson, B.W., Hagerty, M., and Britten, K., 2006a, Variability of volcanic gas emissions during a crater lake heating cycle at Ruapehu Volcano, New Zealand: Journal of Volcanology and Geothermal Research, v. 154, no. 3-4, p. 291-302.

Werner, C.A., Evans, W.C., McGee, K.A., Doukas, M., Tucker, D., Bergfeld, D., Poland, M., and Crider, J., 2007, Quiescent degassing of Mt. Baker Volcano, Washington, USA [abs.]: Geological Society of America, Cordilleran
Section Annual Meeting 103, Bellingham, Wash., 2007, paper no. 26-4.

Werner, C.A., Miller, C., Edmonds, M., and Herd, R., 2006b, Short-term temporal variability of $\mathrm{SO}_{2}$ emissions at White Island, New Zealand [abs.]: Eos (American Geophysical Union Transactions), v. 87, no. 52, V43E-02.

Werner, C., Hurst, T., Scott, B., Sherburn, S., Christenson, B.W., Cole-Baker, J., and Mullan, B., 2008, Variability of passive gas emissions, seismicity, and deformation during crater lake growth at White Island Volcano, New Zealand, 2002-2006: Journal of Geophysical Research, v. 113, no. B01204, 15 p., doi:10.1029/2007JB005094.

White, R., 1996, Precursory deep long-period earthquakes at Mount Pinatubo; spatio-temporal link to a basalt trigger, in Newhall, C.S., and Punongbayan, S., eds., Fire and mud; eruptions and lahars of Mount Pinatubo, Philippines: Seattle, University of Washington Press, p. 307-327.

Wicks, C.W., Jr., Dzurisin, D., Ingebritsen, S., Thatcher, W., Lu, Z., and Iverson, J., 2002, Magmatic activity beneath the quiescent Three Sisters volcanic center, central Oregon Cascade Range, USA: Geophysical Research Letters, v. 29, no. 7, 4 p., doi:10.1029/2001GL014205.

Wood, H.O., 1915, The seismic prelude to the 1914 eruption of Mauna Loa: Bulletin of the Seismological Society of America, v. 5, p 39-50.

Wright, R., Flynn, L.P., Garbeil, H., Harris, A.J.L., and Pilger, E., 2002, Automated volcanic eruption detection using MODIS: Remote Sensing of Environment, v. 82, no. 1, p. 135-155.

Wright, R., Flynn, L.P., Garbeil, H., Harris, A.J.L., and Pilger, E., 2004, MODVOLC; near-real-time thermal monitoring of global volcanism: Journal of Volcanology and Geothermal Research, v. 135, no. 1-2, p. 29-49.

Yun, S., Segall, P., and Zebker, H., 2006, Constraints on magma chamber geometry at Sierra Negra volcano, Galapagos, based on InSAR observations: Journal of Volcanology and Geothermal Research, v. 150, no. 1-3, p. 232-243.

Zebker, H.A., Amelung, F., and Jonsson, S., 2000, Remote sensing of volcano surface and internal processes using radar interferometry, in Mouginis-Mark, P.J., Crisp, J.A., and Fink, J.H., eds., Remote sensing of active volcanism: American Geophysical Union Monograph 116, p. 179-205.

Zweck, C., Freymueller, J.T., and Cohen, S.C., 2002, Three-dimensional elastic dislocation modeling of the postseismic response to the 1964 Alaska earthquake: Journal of Geophysical Research, v. 107, no. B4, 12 p., doi:10/1029/2001JB000409. 


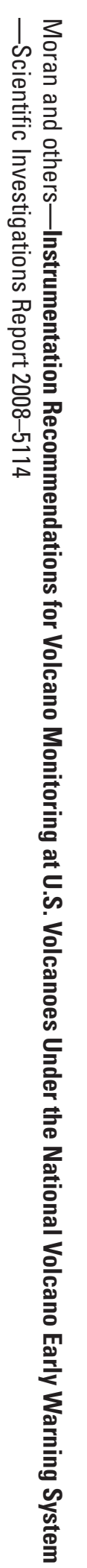

